\title{
CERAMIC ETHNOARCHAEOLOGY IN HUÁNCITO, MICHOACÁN, MEXICO
}

\author{
Eduardo Williams \\ Centro de Estudios Arqueológicos, El Colegio de Michoacán, Martínez de Navarrete 505, CP 59699, Zamora, Michoacán, Mexico
}

\begin{abstract}
This study deals with pottery production in Huáncito, a Tarascan or Purepecha community in Michoacán, Mexico. The information I have obtained by direct observation during a quarter-century of ethnoarchaeological fieldwork in this town allows me to generate hypotheses to aid in the interpretation of the archaeological record. The main goal of this study is to assist in the interpretation of the material record of ceramic production by means of ethnographic analogy. The observations conducted over a long period of time have given me an invaluable diachronic perspective for understanding many aspects of social change and cultural continuity, including patterns of ceramic manufacture, use, and discard, as well as the use of domestic space and the archaeological visibility of potting activities in the context of the households.
\end{abstract}

\section{INTRODUCTION}

This study deals with pottery production in Huáncito, a Tarascan or Purepecha community in Michoacán, western Mexico (Williams 1994a, 1994b, 2014a, 2016a, 2016b, 2017). The information I have obtained by direct observation during more than 26 years of ethnoarchaeological fieldwork in this town allows me to generate hypotheses to aid in the interpretation of the archaeological record, including ceramic manufacture, the use of space in potting households, and the archaeological visibility of potting activities. The main goal of this study is to help in the interpretation of the archaeological record by means of ethnographic analogy. The observations conducted during many years of fieldwork have given me an invaluable diachronic perspective for understanding many aspects of pottery production, as I discuss in this article.

Over the last decades of archaeological research, there have been important changes in the kinds of questions archaeologists ask about ceramic artifacts. Pure description gave way to attribute analysis, useful for developing relative chronologies. Another striking development is the renewed interest in the production methods of ancient craftspeople, as well as research on decoration and design motifs, the study of the physical characteristics of clays and temper, and, more recently, a growing interest in the dynamics of cultural phenomena and processes related to pottery production, use and discard (Kolb 1989:382).

One of the most important developments in the recent evolution of archaeology is the analytical approach called ethnoarchaeology, which has been defined as the study made by archaeologists of variability in material culture and its relationship with human behavior and organization. This research is conducted with contemporary societies and its results are used for building hypotheses useful for archaeological interpretation (Longacre 1991). The goals of an ethnoarchaeological study are to obtain ethnographic information

E-mail correspondence to: williams2129@gmail.com about the cultural behavior linked to material objects, in order to make comparisons with the archaeological information (Thompson 1991; Williams 2005).

Although this analytical perspective and the word "ethnoarchaeology" appeared for the first time over a century ago in the writings of Jesse W. Fewkes (1901, cited by D. Arnold 1991), it is only in recent years that archaeologists have recognized with renewed interest the need to gather data on cultural processes in the present and then apply them to the interpretation of the archaeological record. This is indispensable in order to understand the relationship between the ethnographic context (dynamics) and the archaeological context (statics; Binford 1983).

For the purposes of this investigation, the various terms found in the archaeological literature such as "bridging arguments" (Wylie 2002), "middle-range theory" (Binford 1983), teorías mediadoras (Bate 1988), and "formation theory" (Shott 1998) all have the same meaning: ethnographic fieldwork that tries to relate a cluster of activities and cultural behaviors (in this case, the production, use, and discard of objects made of fired clay) with a particular assemblage and other diagnostic features of material culture that can be used for the interpretation of archaeological contexts through analogy.

Most of the production activities discussed here took place in households. In this regard, the present ceramic industry of the Tarascans of Michoacán is similar to the pottery production patterns of the past, which also relied on a household mode of production. In fact, it has been said that "household production, even of a nondomestic nature, was a family affair, and any discussion of the organization of production in ancient Mesoamerica must consider the organization of the family" (Healan 2014).

According to Hirth $(2009,2011,2013)$, households are the most important social entities of humankind, since all human beings are born into them, and are raised, fed, and frequently receive their education there, as well. Indeed, in premodern societies, most goods were manufactured, stored, and consumed inside households. Hirth 
holds that the term "domestic economy" refers to both what households do, and to the manner in which they are organized in order to satisfy their physical and social needs. Because the household economy has always been the backbone of society, households have always been important, as they perform a wide range of subsistence activities that benefit their members (Hirth 2009:13). The present author has conducted several studies of household activities following an ethnoarchaeological perspective; these studies have dealt with salt making (Williams 2015) and the aquatic lifeway (fishing, hunting, gathering, and manufacture) in Lake Cuitzeo and Lake Pátzcuaro, Michoacán (Williams 2009, 2014b, 2014c, 2014d).

Some recent approaches to the study of domestic production in Mesoamerica have adopted a holistic perspective that attempts to reach a definition and explanation of the organization and technology of the entire craft-producing process, from the acquisition of the necessary inputs to the uses given to the finished products. Another aim has been to attain an understanding of the social conventions and institutions, value systems, distribution mechanisms, and functions of products, all of which influence the design, distribution, use, and meaning of products. In short, the ultimate aim of this holistic approach is to achieve a comprehensive understanding of the material, technological, social, and ideological components of craft-producing systems, while also elucidating their historical, natural, and social context on a regional level (Shimada and Wagner 2007:166-167).

We know that craft specialization existed in Mesoamerica from pre-Hispanic times. Among the Aztecs, for example, domestic production used family members as the work force (Feinman 2001:191). There is clear archaeological evidence throughout Mesoamerica for craft specialists from early times; for example, in the production of objects made of stone, marine shells, and pottery, among others (Feinman 2001:192). In present-day Mexico, we still see potters and many other full-time artisans working inside their house lots, following a custom that has its roots in the most distant past (Berdan 2014; Feinman 2001:193).

According to Hirth (2011:13), the study of craft production is an important field within archaeological research, because it is easily identifiable in the archaeological record through the tools used and the refuse materials that are diagnostic of several manufacture activities. Studying craft production, therefore, offers an approach to understanding the scale and organization of work groups in a given society, for it was a key component of all ancient Mesoamerican societies, and the vast majority of the goods elaborated were made in domestic contexts by independent artisans (Hirth 2011:13).

In the following pages, I present a brief introduction to the methodological aspects of the present research. During my first visit to Huáncito (in the summer of 1990), I selected my informants according to the criteria of accessibility and willingness to take part in the study, and I have been working with the same informants until the present. The study is focused on several families of potters in Huáncito. Ethnoarchaeology typically relies on informants, that is to say individuals or social groups who may assist us in the quest for "methods for reconstructing... [the] representation of social action, social actors, and the timings and spatial locations of social practices" (van Leeuwen 2008:1). The Tarascan potters who have been my primary informants are named below.

The first household pertains to an extended family, composed of Isaac Cayetano Lorenzo (74 years old) and his wife, Amalia Félix Marcelino (67 years old). Isaac and Amalia share their house with their adoptive grandson Pablo (29 years old), his wife Socorro Espicio (28 years old), and their son José Ricardo (six years old). Amalia has a daughter named Elena Felipe Félix, who is 46 years old and lives in an independent household with her husband and their 10 children. Elena's father was the late Daniel Félix, who was married to Amalia Félix Marcelino. Elena is married to Gilberto Espicio Ambrosio and has been living with him for the last 30 years. In another household, not too far from the one mentioned above, live Bernaldina Rivera Baltasar (47 years old) and her husband Alfredo Felipe Félix (who is Amalia's son) with their six children. Both Bernaldina and Alfredo were taught to paint pots by Amalia, as well as Elena. All members of this extended family work making and painting clay vessels, and most of the children are "apprentices" of the craft who work alongside their parents and other adults.

The second household consists of a nuclear family: Fidel Lorenzo Santiago (61 years old) and Lafira Bartolo Santos (62 years old), who share their household with their daughters María de Jesús ("Chaparrita," 39 years old) and Marina (41 years old). Marina's son (Magdaleno, 21 years old) does not live with them full-time because he works in agriculture outside Huáncito but he visits often. Fidel and Lafira's household is employed full-time in pottery making. The designs of their pots are simpler and less diverse than the ones produced by Isaac and Amalia's family, although both houses are very close to each other.

My ethnographic research in Huáncito has relied on participant observation inside many potters' households (not just the ones mentioned above). I have conducted interviews (free format) and applied questionnaires in different parts of the town. I have made plans of each of the houses of my informants, indicating the main activity areas where different stages of the pottery-making process are carried out, such as kneading of clay, molding, and smoothing of fresh clay vessels, decoration (with natural colorants or with storebought paint), and, lastly, the firing of the pots in the kiln. By recording these activities over many years, I have been able to obtain a diachronic perspective of the use of space, as well as to understand the different activities that take place in a house, as discussed later in this article. This aspect of my investigation is very important, because both the use of domestic space and its archaeological consequences are of critical significance to archaeology. In this respect, David and Kramer (2001:65) have stated that different people in different localities perform different activities during different parts of the year. There may be long-term variations both in the activities and in the material culture associated with them.

An important aspect of this research has been the formation of a photographic archive of all activities, illustrating the spatial contexts where these activities take place, the material culture in ethnographic or systemic context, and the decorative styles in the pottery made in each household. We have also carried out a study about the "use life" of the vessels, that is to say the processes of manufacture, use, decay, breaking, and discard in Huáncito and other potter communities in Michoacán (Shott and Williams 2001, 2006).

\section{GEOGRAPHIC AND CULTURAL BACKGROUND}

In this section, I present the general aspects of the research, such as the geographic and ecological context of the community under study, as well as the cultural features of the craftsmen and women, with emphasis on material culture in ethnographic 
context. I will discuss the major changes and continuities seen from the time of my first visit to the town (1990) to the present.

Huáncito is located in a region known as La Cañada de los Once Pueblos, referring to a glen or narrow valley where eleven Tarascan communities are found (Figure 1). According to West (1948), La Cañada is a small and narrow valley, located to the north of the Sierra Tarasca. This is a very distinctive geographic unit, a narrow depression following an east-west direction, and it still is one of the major regions of Tarascan culture. The other regions with a significant Tarascan population are the Lake Pátzcuaro Basin (Kemper 2010), the Tarascan Meseta or Plateau (Beals 1969), and the Lake Zacapu Basin (Friedrich 1970).

In La Cañada, the valley floor is $10 \mathrm{~km}$ long by $2 \mathrm{~km}$ wide, and its altitude decreases steeply from $1,938 \mathrm{~m}$ in its eastern point to $1,780 \mathrm{~m}$ in Chilchota, near its western end. In the western edge of the valley, there is an ancient lava deposit, which at some point in the geologic past interrupted the normal drainage. Subsequent deposits of alluvium, of probable lacustrine origin, behind the lava dam have given form to the wide and flat floor of the western part of the valley. At present, the stream that drains the valley flows through a deep canyon crossing the north part of the lava deposit. Numerous intermittent flows descending from the adjacent hills have built up small alluvial fans along the valley. Like other areas on the margins of the Sierra, La Cañada is favored by numerous springs of great size, which come out of fissures in the eastern and western margins of the depression. The presence of the rich alluvium and abundant water has attracted human settlements in the valley since ancient times (West 1948).

La Cañada is a region of mild weather (Cwa; West 1948:Map 4), where the duration of the frost season is relatively short, 60 days on average. The following vegetation zones have been identified in this area: primarily pine-oak forest (although a great deal has been cut down or has been eliminated for agriculture). The chaparral forest, grasslands, and scrubland are also present. The most abundant soil type in La Cañada is charanda, of reddish-brown color and clayey consistency (i.e., chromic luvisol), produced by weathering of the volcanic rocks in hot summer temperatures and mild winters. The second most widespread soil type here is called t'upúri, the most productive of all humid highland soils (i.e., humic andosol). The texture of this soil is extremely fine, and it retains humidity quite well, therefore it prevents sheet erosion by absorbing water. Among the most productive soils for agriculture in the Tarascan area there are many kinds of soils with a restricted distribution, like the alluvium in La Cañada and the lake deposits in its western end, which contain organic material in abundance, as well as the essential chemical elements, so they can be farmed annually without rest (West 1948:Map 6).

There are relatively few historical sources dealing with La Cañada. The most important source from the early Colonial period is the Relación del Partido de Chilchota [1579], in which we read that:

This town of Chilchota was in another time a great thing, and it has diminished [in importance] because of the pestilence... Its houses are... on a plain without any rocks, good soil. Houses are made of adobe walls and covered by very fine straw. They have small houses: they live two and three married people in one house. They sleep on the floor, on mats they use made of reeds... these Indians declare that in the time of their gentility they were subjects to the Cazonci, lord of the great city of Pátzcuaro, and to him they paid tribute and took the tribute to Pátzcuaro... blankets and shirts and maize... (Acuña 1987:101, my translation).
La Cañada de los Once Pueblos is also known by the Tarascan name of Eraxaman. The head town is Chilchota, known in Tarascan as Zirapo in the sixteenth century. The following towns are currently found in La Cañada (from east to west): Carapan, Tacuro, Ichán, Huáncito, Zopoco, Santo Tomás, Acachuén, Tanaquillo, and Chilchota (Figure 1). The eleventh town is Etúcuaro, although it is located outside of La Cañada, in the easternmost part of the Tangancícuaro Valley (Franco 1997).

These towns are characterized by their proximity to each other, like the case of Tacuro and Ichán, and the short distance between Urén and Chilchota. There only are a few lots of land between Tanaquillo, Acachuén, Santo Tomás, Zopoco, and Huáncito. The river that is born in Carapan and flows through La Cañada has been a link between the towns since antiquity, because its waters were used in the past and are still used today for irrigation in the farmlands inside the valley. Not all towns in La Cañada were originally there, however; they were resettled following orders from Spanish Colonial authorities who decided to congregate all settlements in the Chilchota Valley (another name for La Cañada) by means of a royal edict or Mandato de congregación of 1603 (Franco 1997:25-26).

Very few archaeological investigations have been conducted in La Cañada. A case in point is the work by Migeon (1985), who considered archaeological and historical data, as well as oral traditions, and found that there was a certain cultural continuity in this area from the Late Postclassic (ca. A.D. 1200-1521) to the present. Migeon was able to show that several settlements in La Cañada (Chilchota, Huáncito, and Carapan) are still found in their original (1579) location, while the Spaniards moved the rest during the early Colonial era.

The Relación del Partido de Chilchota has this to say about the town of Huáncito:

Guanastao [i.e., Huáncito]... is a town of up to 25 neighbors. It is a very graceful town of fruit trees and very well provided; through it pass two canals that irrigate the whole town... In this town they get much wheat and many cabbages of good quality... they grow many peaches and figs better than the ones from the other towns... It has better soil than the other [towns], and better temperature... people [here] live like the others, and they all are of one tongue, and have the same way of dress, sleep, tribute and speech (Acuña 1987:118, my translation).

In 1970, Huáncito had a population of around 1,350 inhabitants, of which only 48.3 percent were classified as engaged in economic activities. Close to 90 percent of these were involved in pottery production (according to data from the 1970 census, cited by Jiménez Castillo 1982:17). In Huáncito and other towns of La Cañada, "[f]or some peasants craft work has become the main activity. This is because of the lack of access to farm land" (Jiménez Castillo 1982:18). The other towns in the area where pottery is produced are Santo Tomás, Tacuro, Ichán, Zopoco, and Acachuén (Joaquín 1982:43). There is an important brick-making industry in Chilchota, but this seems to be a recent development (Ramírez 1986:139).

Despite the high fertility of the lands irrigated by the Duero River in La Cañada, most peasant-farmers in Huáncito are unable to produce food beyond their needs of self consumption, because "[a]ll these small landowners sow the land, but during harvest time the product is no greater than five loads... A peasant oftentimes is left with nothing... to sell in a granary" (Joaquín 1982:68-69). 

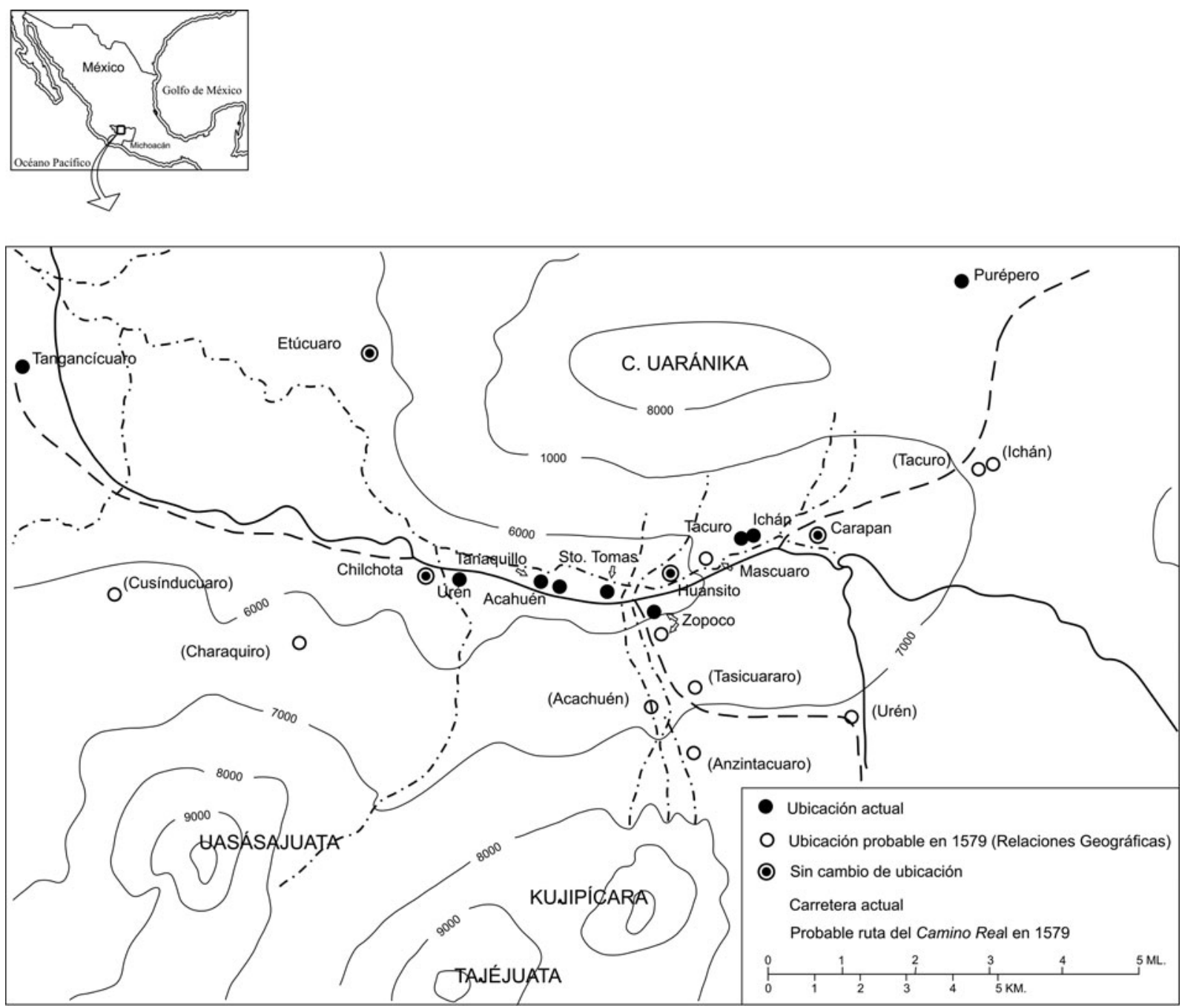

Figure 1. Map of La Cañada de los Once Pueblos, indicating the main towns in the area (adapted from West 1948:Map 14).

Until some 70 years ago, Huáncito, like most other towns in La Cañada, had 100 percent Tarascan speakers (according to the 1940 census, cited by West 1948:Map 12). At present, Tarascan is still spoken there, although most people there are bilingual (Tarascan-Spanish), and Spanish is slowly becoming the dominant language. It is a well-known fact that the Tarascan people constitute one of the most conservative indigenous groups in Mexico in terms of the original elements of their culture, although, of course, there has been much modification due to the cultural mixture and synthesis generated during the Spanish Conquest (Beals 1969). Furthermore, Foster (1965:47) considered communities of potters, in general, to be highly conservative in terms of their "basic personality structure" in comparison with other non-urban groups. Foster thinks that this may be due to the nature of pottery production, which favors those who strictly follow the known and proven customs in order to "avoid economic catastrophe." The potter's craft involves a difficult and complex set of activities, with hundreds of points where a small variation in materials or procedures could spoil the outcome. This generates a basic conservative attitude, a caution against all new things. According to Foster, this goes beyond pottery making and affects the entire worldview of a group (Foster 1965:49-50).
In Huáncito, the production of pottery wares is affected by climatic patterns, which is, in fact, a common occurrence throughout the New World tropics, according to Arnold (1985:61-66). In this town, the clay sources and the firewood are inaccessible or waterlogged during the rainy season, and the potters may find that it is risky to extract the clay from the quarry on account of landslides and the occasional cave-in of a potter's pit. Secondly, rainfall may prevent clay from drying completely, thus affecting the quality of the paste.

In Huáncito, farming is not as important as pottery making, however, so the latter activity is never completely interrupted. The months of higher precipitation here are from June to September, and, during this period, some potters can buy enough clay and firewood to be able to store them and carry on with production in full through the rainy season. In Huáncito, many kilns are covered by a roof to protect them in case of rain, but production decreases in the summer nevertheless (Figure 2).

\section{HUÁNCITO, A COMMUNITY OF POTTERS}

This section deals with the most fundamental aspects of the production of pottery in Huáncito based on what I saw in the first stage of 


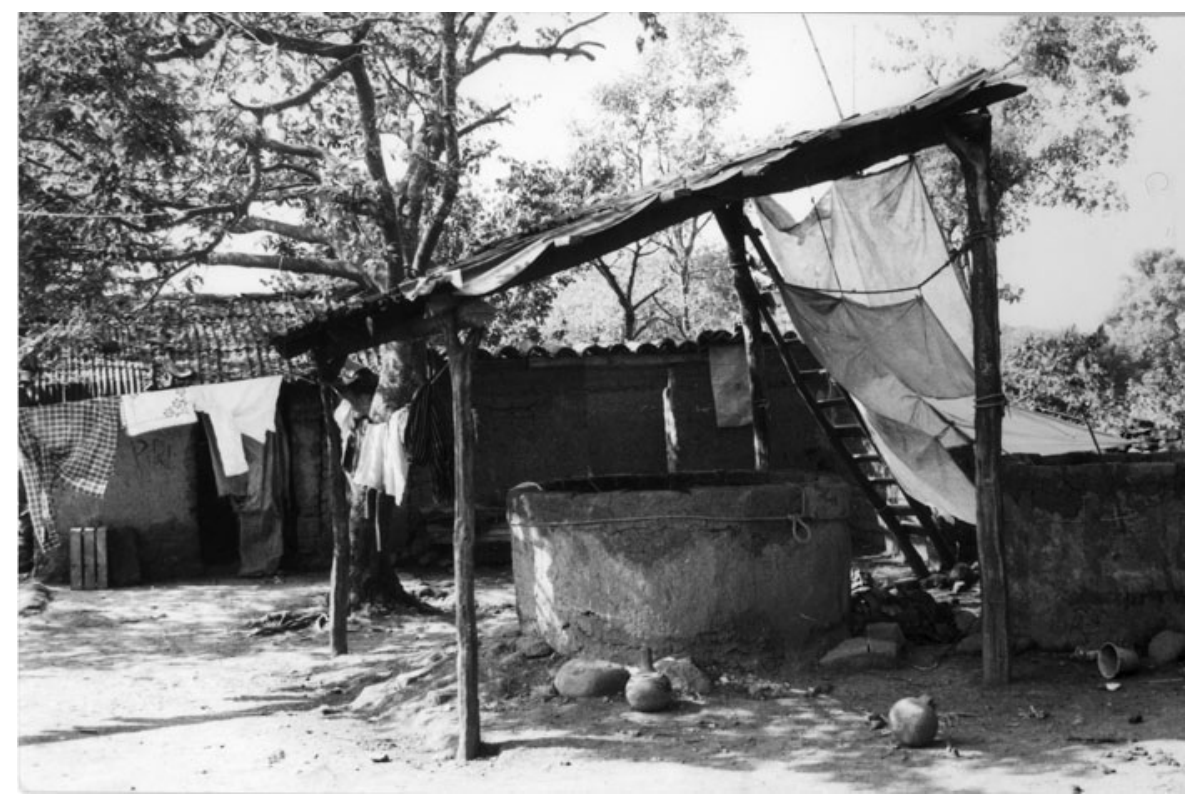

Figure 2. Many kilns in Huáncito are covered by a roof to protect them in case of rain (1990). Photograph by author.

fieldwork (1990-1997). I will also point out the changes that I have seen in the latest stage of fieldwork (2012 to the present). This diachronic perspective is useful to understand social processes and how they are reflected in material culture, that is to say how the ethnographic or systemic context and the archaeological context are related to each other.

\section{Organization of Ceramic Production}

The potter's craft in Huáncito is still an occupation that takes place in the household, with the family as the basic production unit. This kind of familiar organization for the production of crafts is a characteristic of most peasant societies, and it has been described for Tarascan society by Beals (1969), who saw the nuclear family (in some cases the extended family) as the common unit of production. In some cases, two or more men can set up an informal association, or even a society, for instance for long-distance trade or for forest exploitation. The basic kin unit is the nuclear family, to which on occasion are added single brothers or sisters or an elderly person, who may be poor and dependent. Occasional extended families are those in which parents live with one or more sons in the same household and perform all activities jointly (Beals 1969:766).

According to Hirth (2013), the household was a fundamental component of all economic systems in antiquity, as it still is in the present. Most of the food, fuel, and other resources were produced in households, and their importance was such that society simply could not survive without them. Households were not selfsufficient, as we can see in many ethnographic studies in Mexico and in many other places around the world. Exchange networks between several families and other groups within a settlement or a wider area were indispensable in order to compensate the shortcomings that were always present on a local level. Furthermore, the diversity of ecological landscapes ensured subsistence through exchange between groups that lived in areas with different environments. Last, economic specialization by age, ethnicity or gender could increase the diversity and efficiency of production (Hirth 2013:125).
Some pottery-producing families in Huáncito are of the nuclear type, consisting of the father, mother, and their sons and daughters, while others are extended families, including up to three generations and sometimes incorporating, for instance, the husband of a married daughter and their children, together with the head of the family, his wife and children, as well as one or two of his parents.

Different activities related to the manufacture of clay objects can be performed in different parts of the house, although there is a kind of low "table" where the clay is kneaded and placed inside the molds, and painting the pots can be performed there, as well. The potter's kiln is a fixed structure; it is the element with the greatest archaeological visibility in the domestic production spaces observed by the author in Huáncito and other craft-making communities.

The work linked to ceramic manufacture is organized in such a way that each family member has a specific function or functions, although sometimes these divisions are not very strict and a member of the family group can help another one to perform a certain task. For instance, the wife usually shapes the vessels in the molds, as well as doing the drying and polishing, while men or women can perform the decoration of pots indistinctly. The most difficult aspects of production are usually (but not exclusively) performed by men, such as procuring clay (Figure 3 ) or firewood (Figure 4), as well as firing the kiln (Figure 5), although women and children may help out, as well. Nowadays, many children go to school, so they can only help in the activities linked to the potter's craft during their free time.

What follows is a detailed description of each one of the steps linked with pottery production in Huáncito; the order of presentation is more or less the sequence in which each step has to be performed in order to have a successful livelihood on the basis of ceramic manufacture and distribution.

\section{Clay Procurement}

There are several clay deposits on the outskirts of Huáncito, near a stream that flows during the rainy season. In one of the procurement areas, one can see several pits dug by potters in a space of about 250 


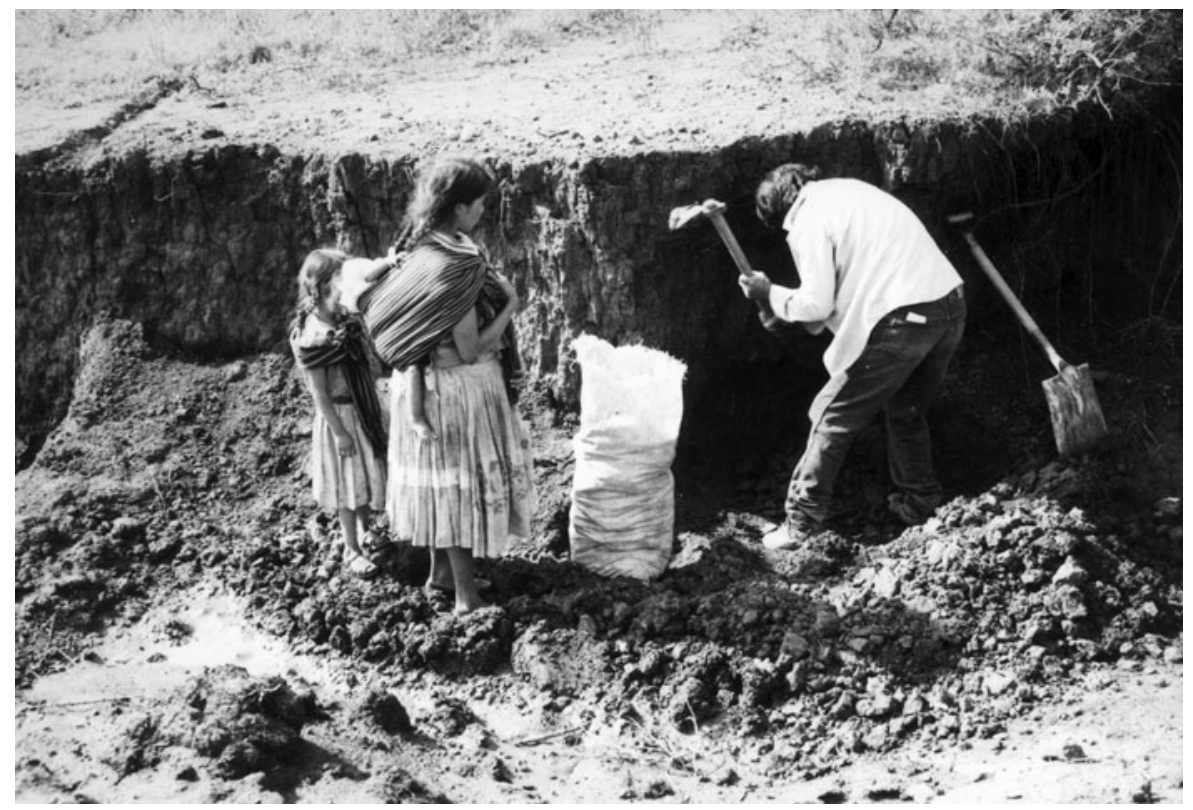

Figure 3. One of the most critical aspects of the ceramic process is procuring clay from the local sources (1990). Photograph by author.

square meters, from which the clay is taken out with a pick, shovel, and wheelbarrow. Some of these pits may be quite deep, up to three meters (Figure 6). After taking the clay from the pit, it is spread out to dry on a flat surface near the pits (Figure 7), where it stays for approximately one day or more, depending on the ambient humidity.

Potters in Huáncito use two kinds of clay, which are classified as barro corriente (coarse clay) and barro fino (fine clay). The first one is found in some natural sediments to the north of the town, inside communal lands, and access is free to whoever wants to use it. The fine clay is located in sediments within lands that are the private property of individuals, so potters have to pay for the right to use this clay (Jiménez Castillo 1982:22).
Around eight sacks of clay (50 kg each) are needed for one kilnload of pots. Sometimes the potter gets his own earth, and he has to pay for grinding it in one of the mills found in the community, while in the early days of fieldwork I was able to see that some potters still used big rocks to pulverize the clay (Figure 8), but this is no longer the case in Huáncito.

\section{Using the Mold to Shape Pots}

The methods for making pottery in Michoacán have already been described by Foster $(1948,1955,1967)$, but it is useful for the present discussion to include a short description of the methods

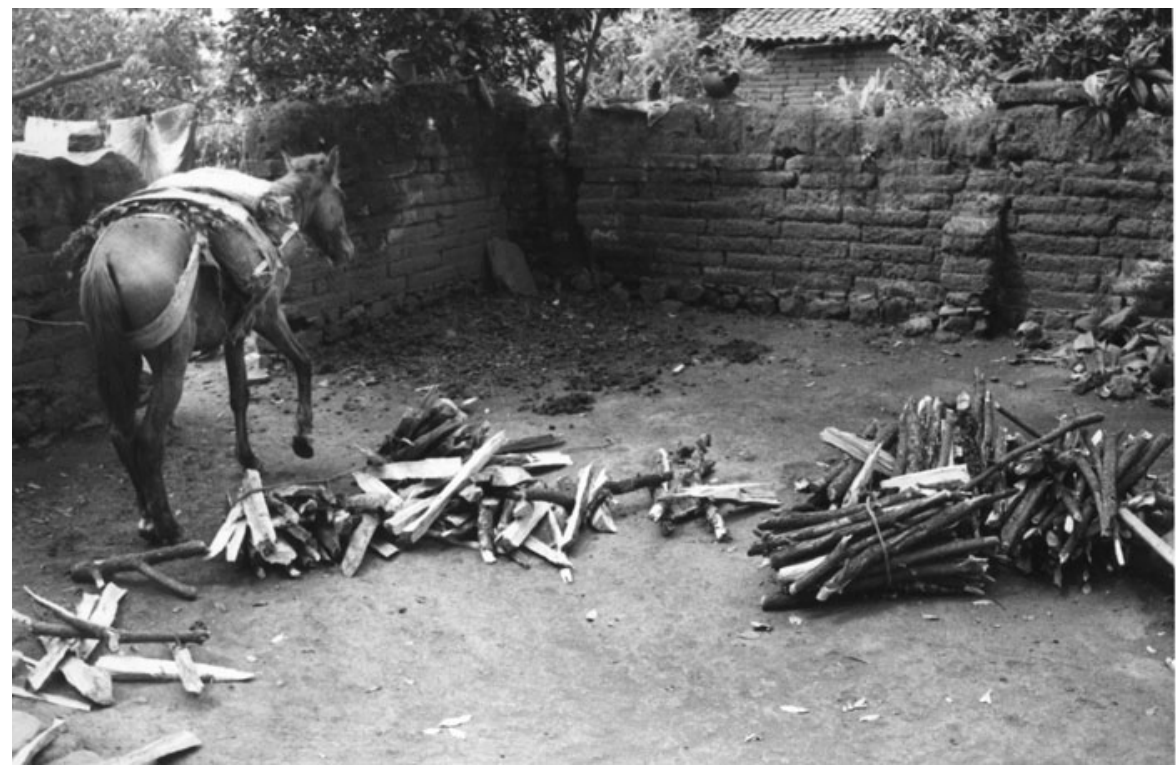

Figure 4. Potters used to go to the hills around Huáncito to collect firewood for the kilns. Nowadays, most potters get their fuel from people who bring it from other towns in trucks, which have replaced the burros and horses of the past (Fidel Lorenzo household, 1990). Photograph by author. 


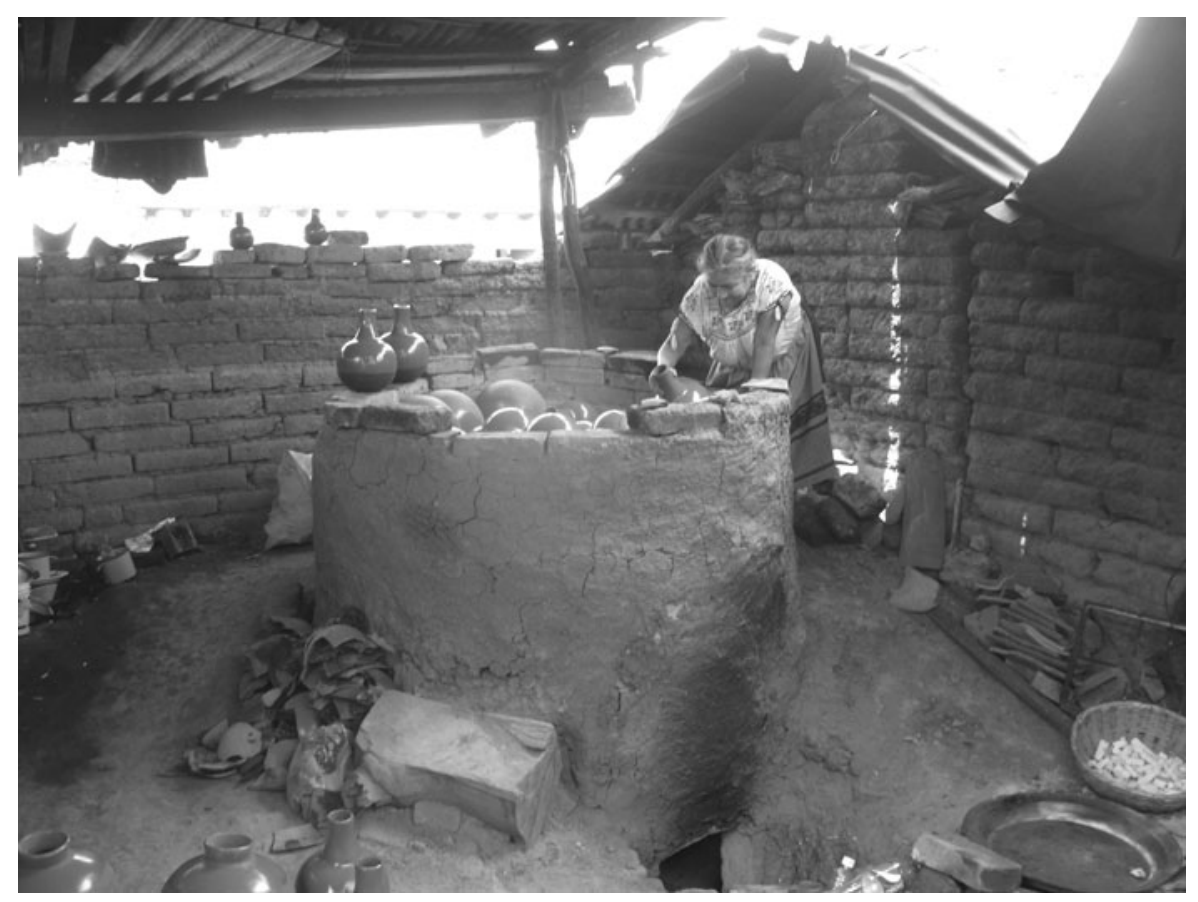

Figure 5. Firing the kiln is a difficult mater that involves great care and knowledge. It is done by men, although women and children may help out as well (Fidel Lorenzo household, 2014). Photograph by author.

and processes of manufacture in Huáncito, as well as some changes we have witnessed over the last few years and the persistence of some traditions over time.

The most common technique for shaping pots is by using the vertical-half mold (Figure 9), the geographic distribution of which is limited to north-central Michoacán and a small portion of western state of México (according to Foster 1967:Figure 15). This technique is used primarily for making cántaros (pitchers), and consists of making a clay tortilla or "pancake" which is cut in half and introduced in each one of the molds. The next step is

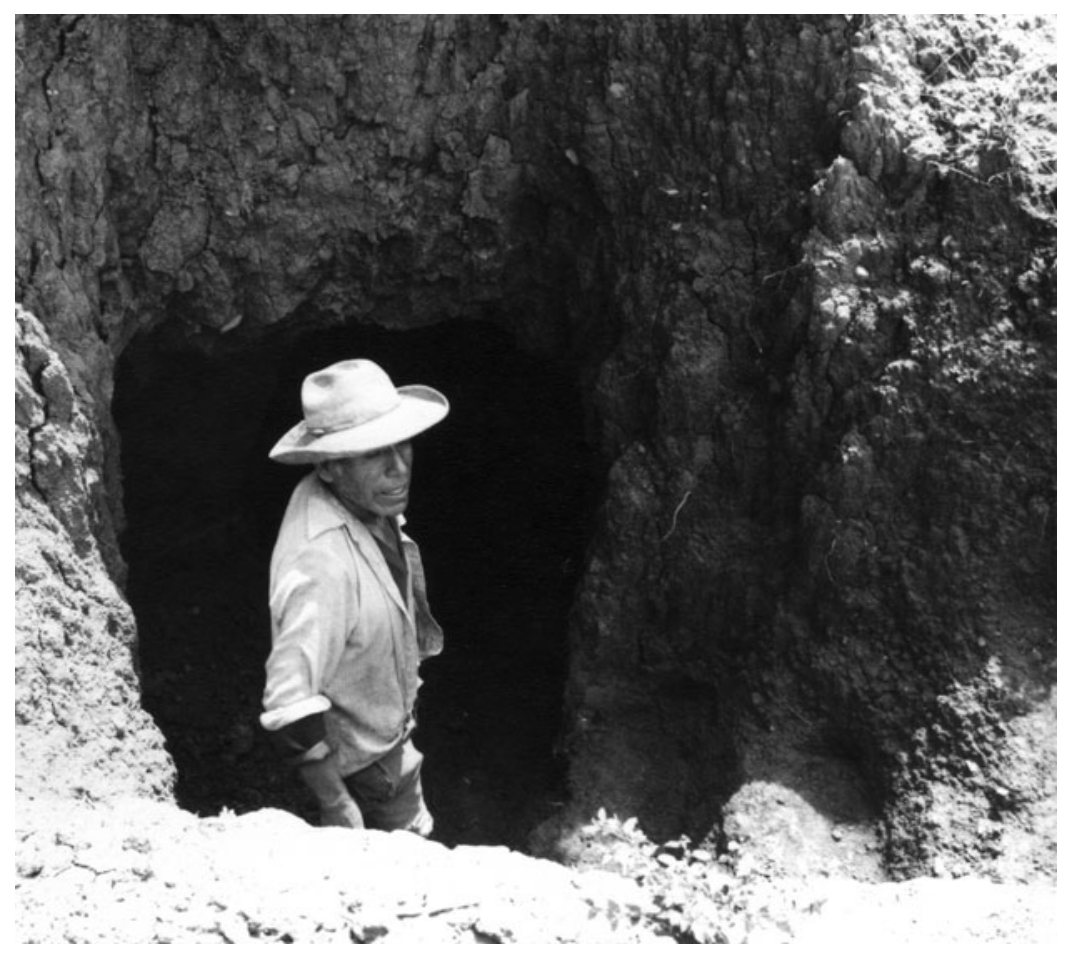

Figure 6. Clay is taken from pits dug by potters with pick and shovel. Some of these pits may be up to three meters deep (1990). Photograph by author. 


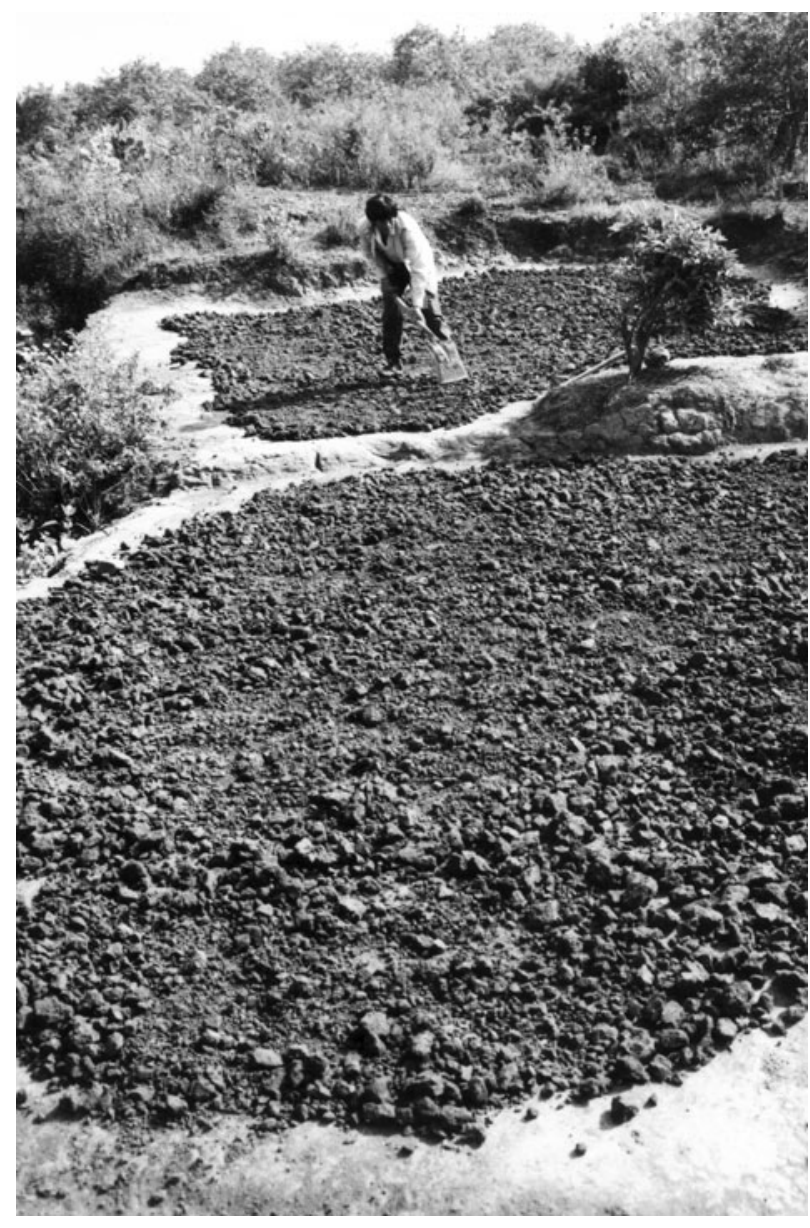

Figure 7. After being taken from the pit, the clay is spread out to dry on a flat surface near the pit, where it stays for approximately one day or more, depending on the ambient humidity (1990). Photograph by author. to smooth the clay with a piece of cloth until it has the shape of the mold. After this both halves are united, the clay is further smoothed on the inside of the vessel, and the mouth or rim of the pot is made even. After a short drying period, the molds are removed, and the potter adds handles, decorations, and glazes. This technique represents a considerable saving of time compared to making pots without molds by hand shaping them as is done, for example, in Veracruz (Krotser 1980).

Arnold (1999:61) holds that the adoption of a molding technology has important implications for the organization of the craft and has a feedback relationship with such organizational variables as "scale" and the amount of space dedicated to production. This has been observed by the author in Huáncito, where a potter using the vertical-half mold is able to make as many as one dozen pots or more in a single day.

\section{Firing the Pots}

Some authors, notably Foster (1955), have mentioned that the kiln used by potters in Michoacán (and elsewhere in Mexico) originated in the Mediterranean area and had been brought to Mexico by the Spaniards in the sixteenth century. Now we know that this was not always the case, because firing technology was quite advanced in pre-Hispanic Mesoamerica (Rice 2015). Virtually every house in Huáncito has a kiln and, in some cases, two or more, although in some instances a potter may use a kiln belonging to a close relative, such as the mother or the mother-in-law. The kiln we see in Huáncito is similar to the ones known elsewhere in Michoacán and other parts of Mexico (see, for example, Foster 1948). It has a simple design, consisting of a circular adobe wall of around 1.5 $\mathrm{m}$ in diameter and $1.6-1.8 \mathrm{~m}$ high. The firebox or hearth is underground, and to reach it there is an excavation outside the kiln. The kiln is separated from the firebox by a grill made of stone, brick, vessels, or potsherds placed more or less at floor level. In most

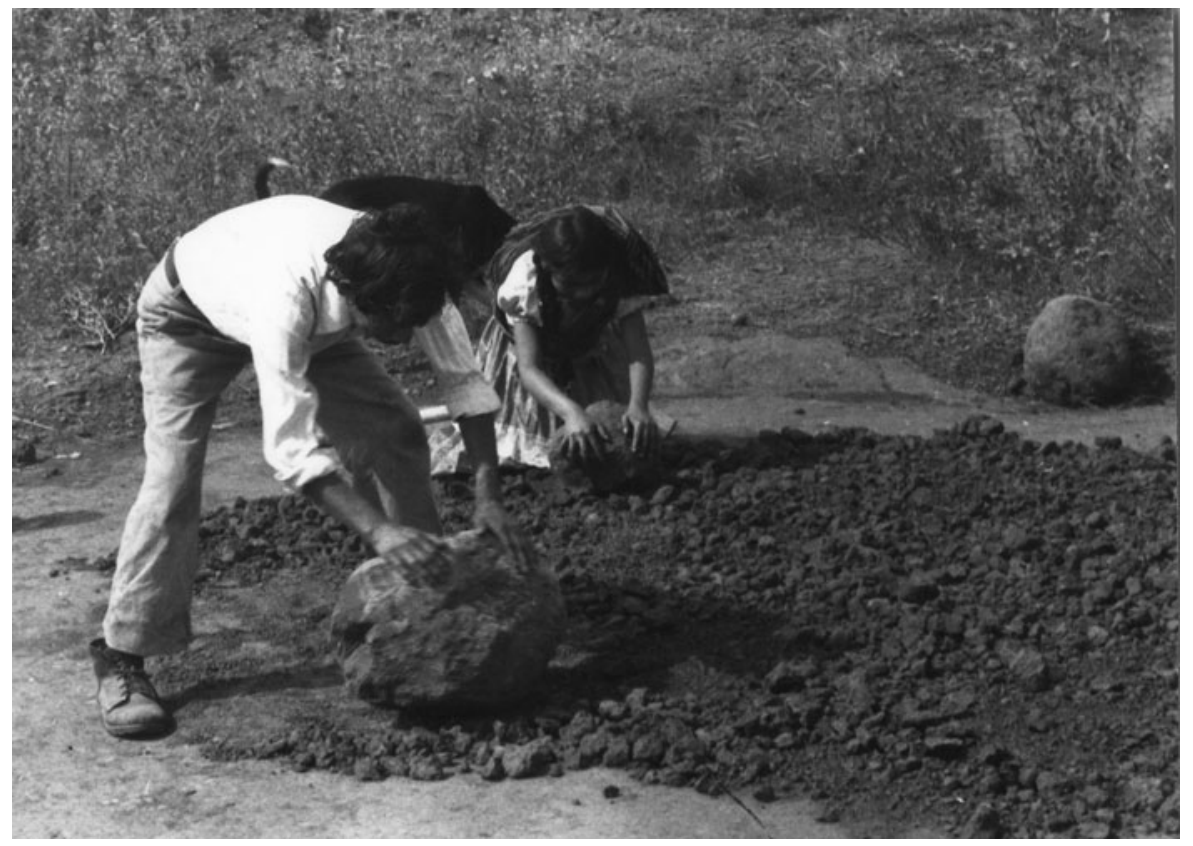

Figure 8. Until some 20 years ago, potters still used big rocks to pulverize the clay but this is no longer the case in Huáncito (1990). Photograph by author. 


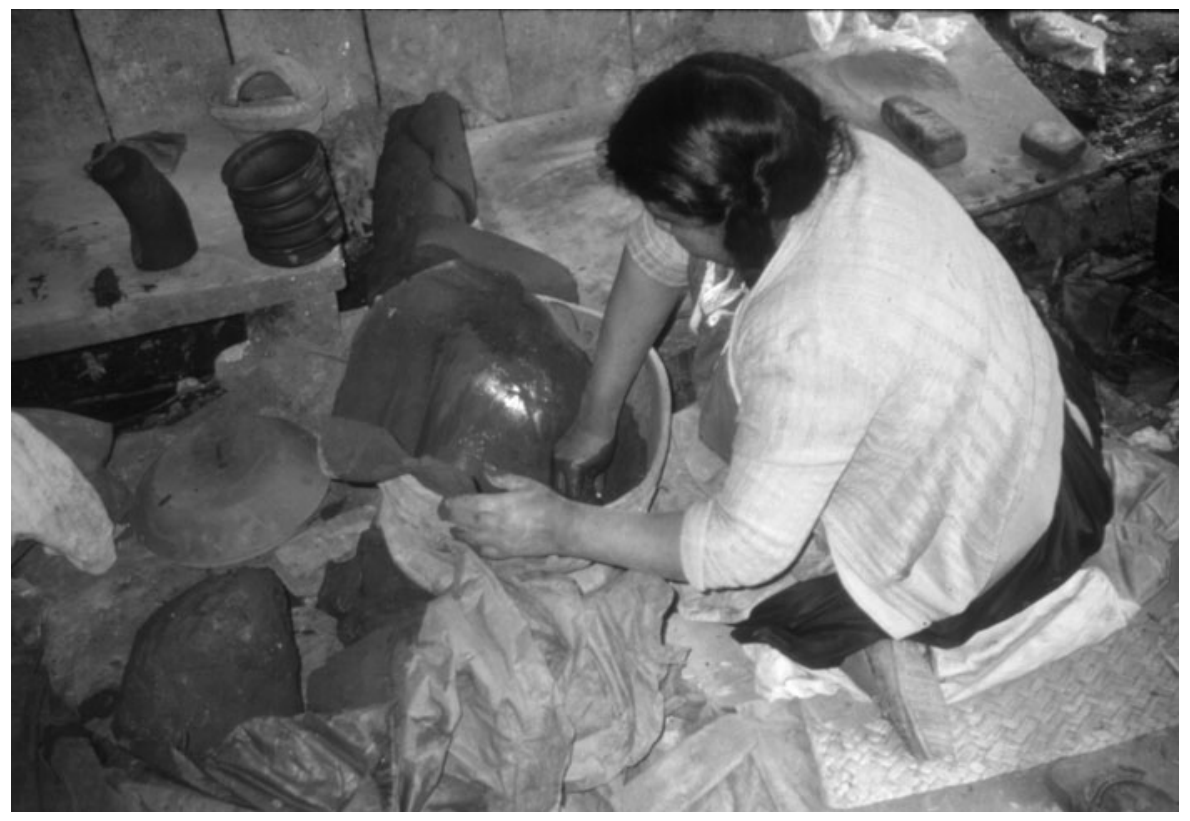

Figure 9. The vertical half-mold technique consists of making a clay tortilla or "pancake," which is cut in half and placed in each one of the two molds. The next step is to smooth the clay with a piece of cloth until it has the shape of the mold (1990). Photograph by author.

cases, this grill rests on top of a central post made of stone, called macho (Foster 1955:10).

A kiln in Huáncito may hold six dozen, mid-sized cántaros, which take about 10 hours to be fired, using one or two loads of firewood. Pinewood is preferred, and the potters used to buy it from people from nearby towns such as Zopoco and Tanaco. The forest is denuded around Huáncito, and there are only a few trees near the town. Nowadays, fuel is brought by truck from several towns in La Cañada. Fuel consumption in Huáncito is considerable, because, in addition to the kilns, virtually all the kitchens also depend on firewood for fuel.

Two loads of fuel (about 55 or $65 \mathrm{~kg}$ each) are enough for one kiln-load of pottery during the dry season, while three loads are needed in the rainy season because the firewood is wet and burns more slowly and less efficiently. In the past, the potters themselves used to bring their own firewood from the hills; they would go out between four and five in the morning with their beasts of burden (horses, mules, or donkeys) and would come back by midday. The kind of firewood used depends on what is going to be fired in the kiln, for example pots with greda (glazed ware) require pinewood, whereas madroño (Arbutus) or encino (oak) is used for unglazed pots. In order to burn the glaze properly, the pots have to be fired twice in the kiln. The first time, the fresh clay is hardened and, in the second firing, the glaze is melted down. Firing is one of the most critical and uncertain aspects of the ceramic process, because it is very hard to know how many pots are going to come out of the kiln whole and in good condition, and how many will be spoiled, completely broken, or flawed (e.g., fire stains, cracking, warping, and others) in a way that will reduce the selling price. Any minor variation in the temperature of the kiln, in the humidity of the fresh vessels within the kiln, or in the kind of firewood used, may cause the pots to crack or to come out with smoke stains or other imperfections. It takes an experienced potter to manage a firing in which all pots come out in perfect condition. In fact, this level of skill is stressed in one of the earliest accounts of Mesoamerican potters and their craft, written in the sixteenth century by friar
Bernardino de Sahagún, whose Aztec informants told him that a good potter was usually a "wiry, active, energetic" person. The good potter was a skilled man or woman who worked with clay, who was "a judge of clay - thoughtful, deliberating; a fabricator", he or she was a "knowing person, an artist... skilled with his [or her] hands" (Sahagún 1961:42).

As we can see in Table 1, firing the kilns in Huáncito requires much firewood, which may aggravate the problem of deforestation in the area. People all over the world are increasingly worried about the availability of fuel for domestic and industrial activities. Many urban centers and rural communities, above all in developing countries, are facing the problem of widespread deforestation, because of the demand for firewood for cooking (Figure 10), firing pottery, construction, and production of crafts (Sheehey 1988). Michoacán, like the rest of Mexico, is faced with this problem and many other ecological issues. These problems were no doubt present in the pre-Hispanic world, in fact the pressure on fuel resources may have increased dramatically in ancient times with population growth, since transport technology was limited to porters with tumplines, and alternative energy sources were quite limited (Sheehey 1988:203).

At present, in La Cañada and most of Michoacán, one can see high levels of deforestation. In addition to the huge amounts of firewood used in the kilns in Huáncito and other craft-producing towns, the kitchens in many homes use firewood as the primary, and sometimes the only, fuel source. Because of this situation, I have been trying to answer the following questions regarding the ecological impact of the pottery industry: (1) How many pottery-making households are there in Huáncito at the moment? (2) How many kilns are there per potter's household? (3) How frequently are the kilns fired in each household? (4) How much firewood is used in each firing? (5) What other uses are there for firewood (for instance, cooking)? (6) Roughly how much firewood is consumed in this town during a certain period of time?

The questions stated above have obvious implications for the study of ceramic ecology in the region. Although at present it is 
Table 1. Fuel consumption in pottery-producing households in Huáncito (2014). This table is based on a census I made in many potters' households in Huáncito in 2014. About 50 percent of informants responded to my questions. Firewood is measured in cargas (cg) or loads of ca. 55 or $65 \mathrm{~kg}$ each.

\begin{tabular}{|c|c|c|c|c|}
\hline Head of household & $\begin{array}{l}\text { Amount of fuel used } \\
\text { in kiln }\end{array}$ & How often kiln is used & $\begin{array}{l}\text { Amount of fuel used in } \\
\text { cooking }\end{array}$ & Remarks \\
\hline Fidel Lorenzo & $\begin{array}{l}3 \mathrm{cg} \text { (dry season); } \\
4 \mathrm{cg} \text { (wet season) }\end{array}$ & Every eight or 15 days & - & - \\
\hline $\begin{array}{l}\text { Leonardo Hernandez } \\
\text { Secundino }\end{array}$ & $2.5 \mathrm{cg}$ & Every 15 days & - & - \\
\hline Eduardo Pascual Diego & $9 \mathrm{cg}$ & Three times per week & $1 \mathrm{cg}$ per week & Both gas and firewood are used for cooking. \\
\hline José Sabino Pérez Ambrosio & $8 \mathrm{cg}$ & Every 15 days & $1.5 \mathrm{cg}$ per week & $\begin{array}{l}\text { Both gas and firewood are used for cooking, but } \\
\text { the latter is preferred. }\end{array}$ \\
\hline Victoriano Magaña Felipe & $8 \mathrm{cg}$ & Every 15 days & $2.5 \mathrm{cg}$ per week & - \\
\hline Elvia Cayetano Moreno & $\begin{array}{l}3 \text { cg (dry season); } \\
4 \text { cg (wet season) }\end{array}$ & Every 15 days & $\begin{array}{l}1 \text { cg every two to three } \\
\text { days }\end{array}$ & - \\
\hline Gildardo Magaña Morales & $4 \mathrm{cg}$ & Every 15 days & $3 \mathrm{cg}$ per week & - \\
\hline Rosalino Cipriano Espicio & $4 \mathrm{cg}$ & Three times per month & $1.5 \mathrm{cg}$ per week & - \\
\hline Javier Cayetano Inés & $?$ & Every 15 days & - & - \\
\hline Gabriel Silverio Alejo & $\begin{array}{l}3 \mathrm{cg} \text { (small kiln); } 6 \mathrm{cg} \\
\text { (large kiln) }\end{array}$ & $\begin{array}{l}\text { Three times per month } \\
\text { (small kiln); once per } \\
\text { month (large kiln) }\end{array}$ & $1 \mathrm{cg}$ per week & $\begin{array}{l}\text { House has gas but it is rarely used for cooking; } \\
\text { firewood is preferred. They have two kilns: one } \\
\text { small and one large. }\end{array}$ \\
\hline Gregorio Antonio Cruz & $\begin{array}{l}4 \mathrm{cg} \text { (small kiln); } 5 \mathrm{cg} \\
\text { (large kiln) }\end{array}$ & Every 15 days & $1 \mathrm{cg}$ per week & $\begin{array}{l}\text { House has gas but firewood is preferred for } \\
\text { cooking. In the wet season, one cg extra is used } \\
\text { per firing. They have two kilns: one small and } \\
\text { one large. }\end{array}$ \\
\hline Juan Baltazar Cipriano & $\begin{array}{l}3 \mathrm{cg} \text { (small kiln); } 5 \mathrm{cg} \\
\text { (large kiln) }\end{array}$ & $\begin{array}{l}\text { Every eight days (both } \\
\text { kilns); }\end{array}$ & $2 \mathrm{cg}$ per week & $\begin{array}{l}\text { This house has two kilns: one small and one } \\
\text { large. }\end{array}$ \\
\hline Mario Diego Saucedo & $5 \mathrm{cg}$ & Every 15 days & $1 \mathrm{cg}$ per week & $\begin{array}{l}\text { This house uses gas for a water heater for the } \\
\text { shower, and occasionally for cooking. The main } \\
\text { fuel used in the kitchen is firewood. }\end{array}$ \\
\hline Luis Baltazar Molina & $10 \mathrm{cg}$ & Every eight or 15 days & $2 \mathrm{cg}$ per week & $\begin{array}{l}\text { Gas is used for heating the shower and firewood } \\
\text { for cooking. }\end{array}$ \\
\hline Raúl Lorenzo Espicio & $6 \mathrm{cg}$ & Every eight days & $\begin{array}{l}2 \text { cg every } 15 \text { or } 22 \\
\text { days }\end{array}$ & $\begin{array}{l}\text { Gas is used for heating the shower and firewood } \\
\text { for cooking }\end{array}$ \\
\hline Francisco Lorenzo Santiago & $3 \mathrm{cg}$ & Every eight days & $3 \mathrm{cg}$ every two weeks & - \\
\hline Sergio Saucedo Uribe & $5 \mathrm{cg}$ & Every 15 days & $1 \mathrm{cg}$ every three days & $\begin{array}{l}\text { Gas is used for heating the shower and firewood } \\
\text { for cooking. }\end{array}$ \\
\hline Esperanza Santiago Ramos & $4 \mathrm{cg}$ & Every eight days & $0.5 \mathrm{cg}$ per day & $\begin{array}{l}\text { Gas is used for heating the shower and firewood } \\
\text { for cooking. }\end{array}$ \\
\hline Jesús Santos & $8 \mathrm{cg}$ & Every 15 days & $1.5 \mathrm{cg}$ per week & - \\
\hline Fidel Santos & $9 \mathrm{cg}$ & $?$ & $0.25 \mathrm{cg}$ every day & - \\
\hline Sebastián Joaquín Cayetano & $6 \mathrm{cg}$ & $?$ & $2 \mathrm{cg}$ per week & This household has two medium-sized kilns. \\
\hline Adolfo Espicio Magaña & $4 \mathrm{cg}$ & $\begin{array}{l}\text { Every } 15-22 \text { days } \\
\text { (rainy season); } 8-15 \\
\text { days (dry season) }\end{array}$ & $2-3 \mathrm{cg}$ per week & - \\
\hline Gildardo Lucas & $6 \mathrm{cg}$ & $?$ & $3 \mathrm{cg}$ per week & - \\
\hline
\end{tabular}

difficult to make a projection of current fuel consumption, much less in the pre-Hispanic past, the questions mentioned above would be a first step to suggest a tentative figure, not unlike what Sheehey (1992) accomplished in Teotihuacan.

\section{Pottery Decoration}

In Huáncito and other craft centers in Michoacán, potters use charanda to paint pots with a characteristic red hue; charanda is also used as slip to cover the whole pot surface, therefore it is an indispensable substance that the potters buy by the liter from people who come from the nearby town of Tarecuato. Charanda is only found in this town, and in order to extract it one needs permission from the local authorities.
The charanda is dissolved with water in a wooden tray, applied to the pot with a brush (Figure 11), and then polished with a cloth before the pot is fired in the kiln. The potters also use a natural source for black paint, small stones from ant nests found in Zirahuén, a lake in north-central Michoacán. Very few people are still using these natural colors for painting pots, however, because they are too expensive. Several potters told me that they only use natural colors when they have a special order from certain customers. Nowadays, most craftspeople in Huáncito use industrially produced paints, which have two main advantages over natural colorants: they are cheaper and are applied to pots after firing, so no time is wasted on painting pots that will probably break or become damaged during firing. The decoration motifs are usually naturalistic, including flowers, birds, rabbits, and other animals. Although there is a certain degree of uniformity in the wares 


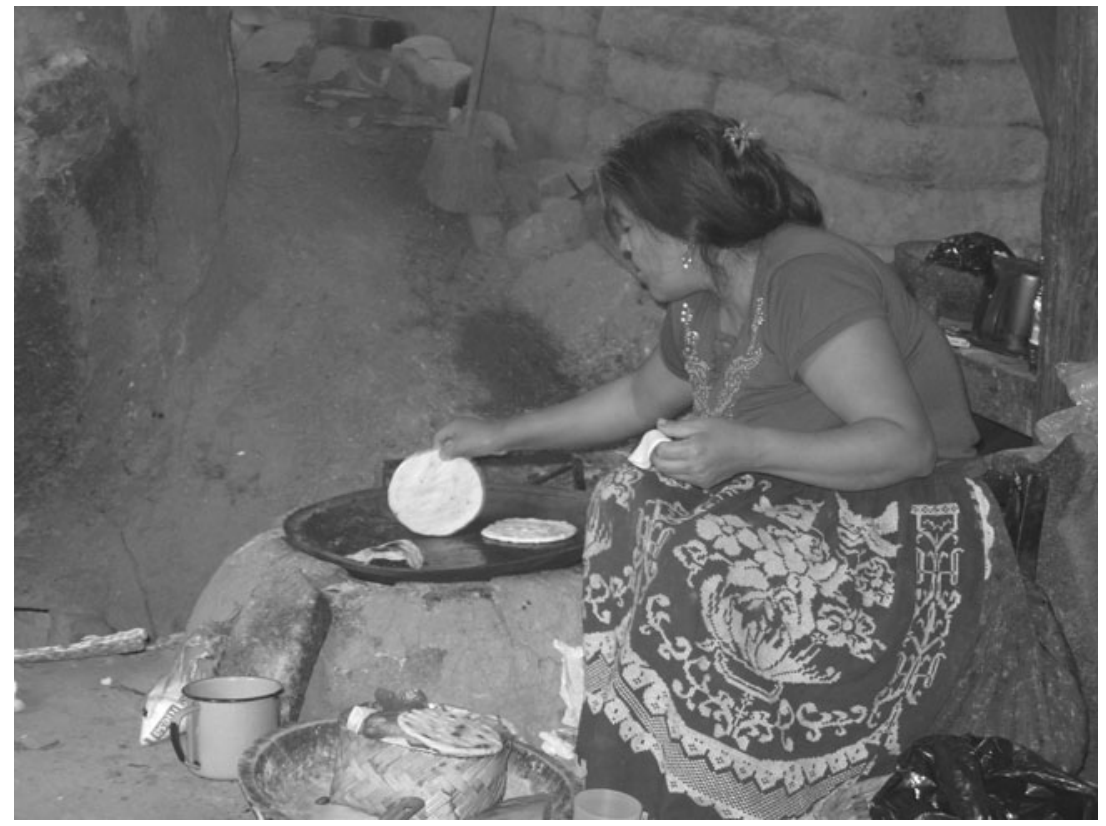

Figure 10. There is a high demand for firewood in Huáncito, as it is used to cook in addition to firing pottery in the kiln (Fidel Lorenzo household, 2014). Photograph by author.

produced throughout this town, each craftsman or woman has his or her own personal style, and the same design will be performed differently in each domestic workshop.

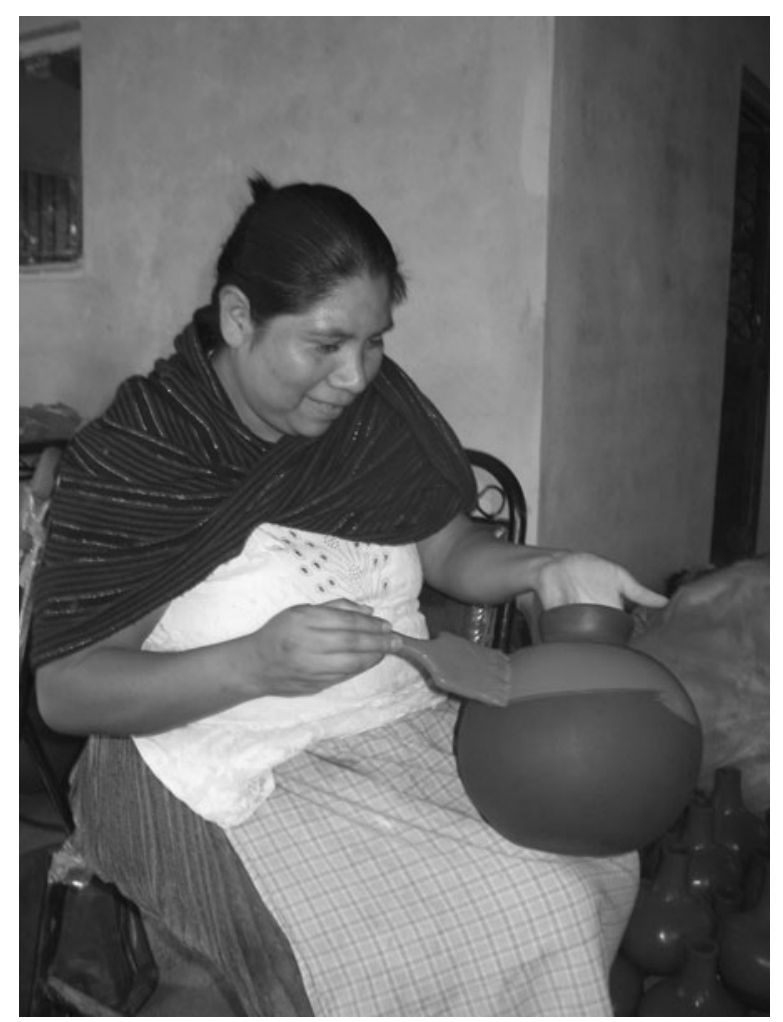

Figure 11. The charanda is a red earth used as slip in Huáncito and many other Tarascan towns in Michoacán. It is dissolved with water in a wooden tray, and applied to the pot with a brush (Isaac Cayetano household, 2014). Photograph by author.
One of the families with whom I worked in the first stage of the research in Huáncito (1990-1997) is that of Isaac and Amalia Lorenzo. I revisited their household in 2013-2015, and was able to see that many important changes have taken place in the family, which are reflected in the pottery, both the shapes of the vessels and the decoration motifs. Amalia's daughter Elena is now living in an independent household with her husband and children, and Pablo (Isaac and Amalia's adoptive grandson) is now married and lives with his wife and son in a room in Isaac and Amalia's house. Elena's 10 sons and daughters, as well as Pablo's son, have joined the domestic work force, contributing their own style to the craft. This situation has allowed me to see how a ceramic style is evolving and being transmitted from one generation to the next, including vessel form, motifs, style of decoration, and manufacture techniques.

\section{PROCESSES OF CHANGE AND PERSISTENCE IN A CERAMIC TRADITION}

Arnold (2008) discusses important aspects of change and persistence over time in traditional ceramics; he holds that understanding the relationship between pottery-making and society is of fundamental importance for archaeology. It is inevitable that pottery production and distribution change over time, and these changes provide fruitful sources of information to make inferences about an ancient society (Arnold 2008). Like Arnold, I am interested in defining precisely how changes in ceramics and its production reflect history in general and the social, political, and economic changes in a given society. In other words, we would like to know how social changes are materialized in a society's ceramic traditions (Arnold 2008).

One of the innovations I have witnessed in Elena's household involves a decoration technique I had never seen in the past. It involves taking a vessel out of the kiln just after firing and putting it in a metal tub full of sawdust and black earth. Once out of the 
tub, the pot shows a very distinctive color, quite different from the other pots in Huáncito.

One of the goals of the present study is to determine in what way innovations like the one mentioned above are transmitted throughout a community of potters. According to Arnold (1989: 74), the relationship between style and society is one of the most important subjects of archaeological research. Archaeologists have proposed several models linking style with social behavior. One of these models is based on kinship, in which patterns of descent and residence account for the transmission of a decorative style from one generation to another.

Arnold has proposed the hypothesis that a kinship model may explain the transmission of a ceramic style. Arnold believes that this model is valid in the case of a modern peasant society like the one he studied in Ticul, Yucatán, Mexico. Pottery production in Ticul is aimed almost entirely at the craft trade outside the community, as is the case in Huáncito. Arnold's study of Ticul's potters shows that most potters learned the craft in the household where they live, and their father lives in the same household. Arnold holds that a patrilineal-patrilocal model accounts for learning patterns among potters in Ticul (Arnold 1989:179).

Arnold thinks that pottery making is learned in traditional societies through imitation and practice, rather than by direct teaching. Learning a craft implies learning a series of complex motor patterns used in manufacture, in combination with cognitive knowledge of raw materials (such as clays, non plastic additives, and fuels), and knowledge of processes like fabrication and firing. The most effective and efficient learning of pottery making takes place during childhood, because the child is exposed to the craft during a period of several years before adulthood. Another reason learning a craft during childhood is efficient is because learning does not compete with subsistence activities, as would happen when an adult learns to make pottery. Learning the potter's craft in a traditional setting is best accomplished in the household during childhood, because skills and knowledge can be acquired and learned on a daily basis (Arnold 1989:180).

Arnold's study shows that a model based on kinship is valid for linking the learning and residence patterns in a community of potters. This approach has important implications for identifying social groups in the archaeological record (Arnold 1989:180), and the same strategy was followed by the present author in a recent study (Williams 2016a), suggesting that ceramic style in Huáncito (in particular, decoration of vessels) is transmitted through kinship networks and is affected by the patterns of residence (Figure 12), as suggested by Arnold (1989) and others, such as Hardin (1970). These relationships would be visible in the archaeological record.

\section{Commercialization of Pottery}

Most Huáncito potters sell their wares directly in town, to people who come from cities in the region (Apatzingán, Morelia, Zamora, or Guadalajara); they may be merchants or somebody who has requested an order of dishes, ashtrays, pots, and so on. Pottery is also sold to acaparadores or middlemen, also known as "coyotes," who may have shops in town or on the highway near Huáncito (Figure 13). Middlemen also include rescatones, who buy pottery and take it as far as Lázaro Cárdenas (on the Michoacán coast), Guadalajara, Mazatlán (Sinaloa), and Baja California. Potters are always in debt to these middlemen, because they pay part of the production in advance and thereby establish a relationship of economic dependence on craftspeople. When a load of pots is taken out from the kiln, the middlemen judge the quality of the pots: for example, de primera (first quality) means

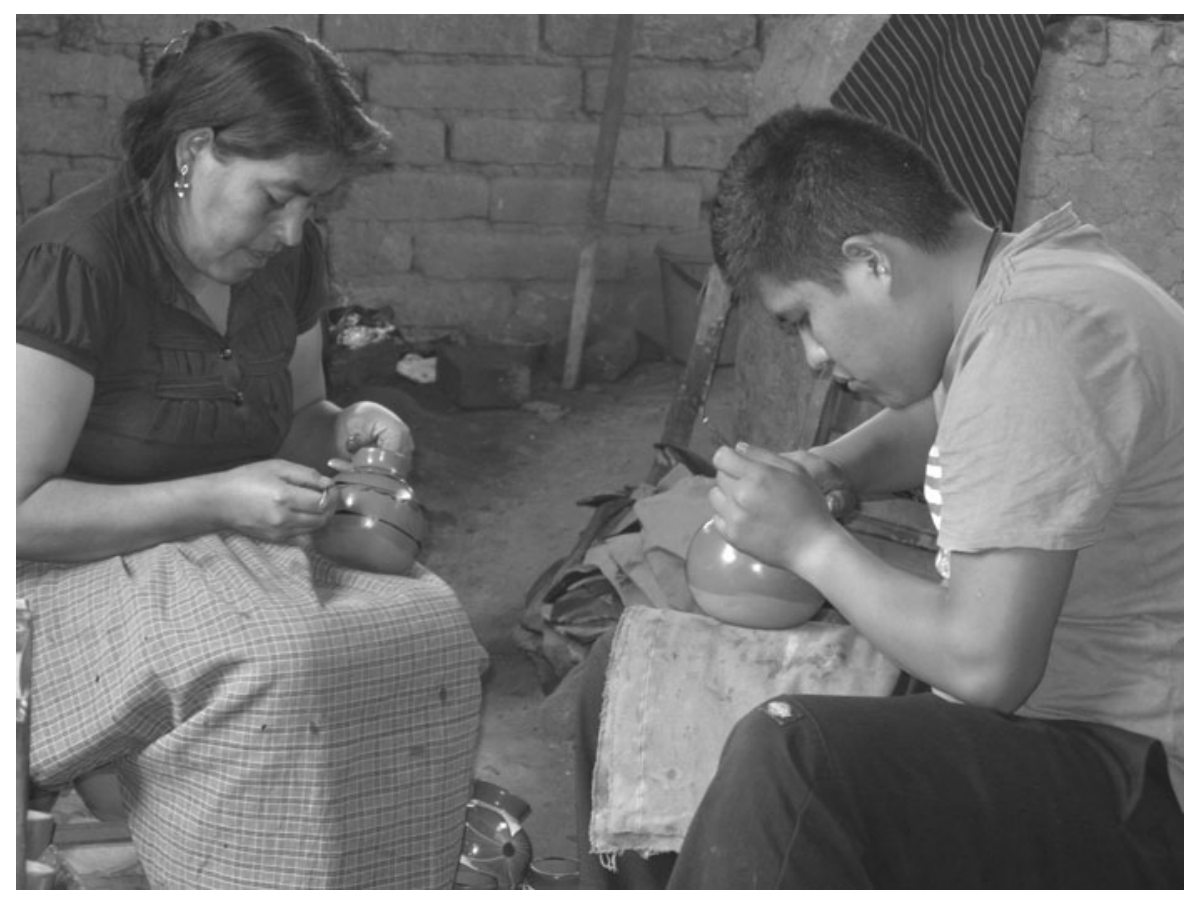

Figure 12. In many communities where traditional crafts are manufactured, the household is an arena in which the daily interaction among members of the same kin group reinforces the processes of learning, and the transmission of a style of decoration (Marina and her son Magdaleno painting pots in the Fidel Lorenzo household, 2014). Photograph by author. 
that the items are perfect and will command a full price. If the pots are misfired, have smoke stains or any other imperfection, they will be considered de segunda (second quality) and the potters will receive less money. When the pots are cracked or otherwise useless for their desired function they may be used for making piñatas. Finally, a pot that is not functional in any way will be thrown away. In some households one can see pots that are recycled as flowerpots once their use-life is over (Figure 14).

Some potters take their own wares to some of the places mentioned above. Once in Apatzingán, for instance, they go to nearby towns where they sell their products in the markets. They usually carry their pots in bundles made with sacks padded with twigs and grass for protection (Figure 15). One can see them waiting on the highway (in La Cañada or near Zamora, La Piedad, and other towns) for a lift in one of the many "trailers" or trucks that pass on the highway. I have seen Tarascan craftsmen and women selling their wares as far afield as San Luis Potosí.

\section{ARCHAEOLOGICAL IMPLICATIONS}

A traditional pottery industry like the one we are discussing here should not be viewed as a static reminder of an "ancient past." For Schiffer (1988), the irreducible core of archaeology is the effort to determine and explain the relationships between human behavior and material culture at every moment and in all places. The principles behind material culture in a dynamic context are known as "correlates" and they are discovered through ethnoarchaeology or comparative ethnography (Schiffer 1988:469).

Ethnoarchaeology is not solely concerned with the relationship between activities carried out in the present and their material or archaeological consequences. We are also concerned with recording social change and cultural persistence; this is essential to understand the cultural, historical, and even artistic aspects of the potters' life and their products in many areas of Mesoamerica and beyond.
Lackey (1982) was interested in change and persistence in her study of pottery manufacture in Acatlán, Puebla (see also Foster 1960). During the time of Lackey's fieldwork (in the 1970s), she saw that many domestic wares that were sold in Acatlán's market on Sundays reflected a centuries-old ceramic tradition, with some items, like molcajetes (grater bowls), that were almost identical to their counterparts from the Postclassic period. Only the shape of the supports had changed (Lackey 1982:25). Lackey also states that in many parts of Mexico, however, the cheapest pottery vessels, together with plastic containers, were replacing more traditional ceramic wares. As a result of this, many potters had to adapt to a decreasing demand by modifying their production for a lower-end market, or by leaving the craft altogether. Lackey further says that when demand for wares for use in the home is low, many craftspeople shift their production to decorative items for selling outside their home communities. These items are not transported to market, but rather are handed over to middlemen who come to town periodically in order to load up their trucks with pottery bought directly from the artisans (Lackey 1982:24-25).

Lackey says that, through history and virtually all over the world, most potters have traditionally been poor, anonymous, and lacking in status, although in Mexico the most accomplished craftsmen and women are beginning to receive some recognition, if only to encourage tourism. Many ceramists and practitioners of other traditional crafts are receiving international recognition now, and their works command high prices (Lackey 1982:37). In Huáncito, the Casa de Artesanías, a government agency that supports traditional crafts (based in Morelia, the capital of Michoacán), has a direct influence on the work of most potters, by organizing contests with cash prizes for the most outstanding creations.

The changes seen by the author during the last 26 years in Huáncito are not limited to stylistic modifications or the incorporation of new techniques in the potters' repertoire. I have also seen transformations in the architecture of most houses, which are now

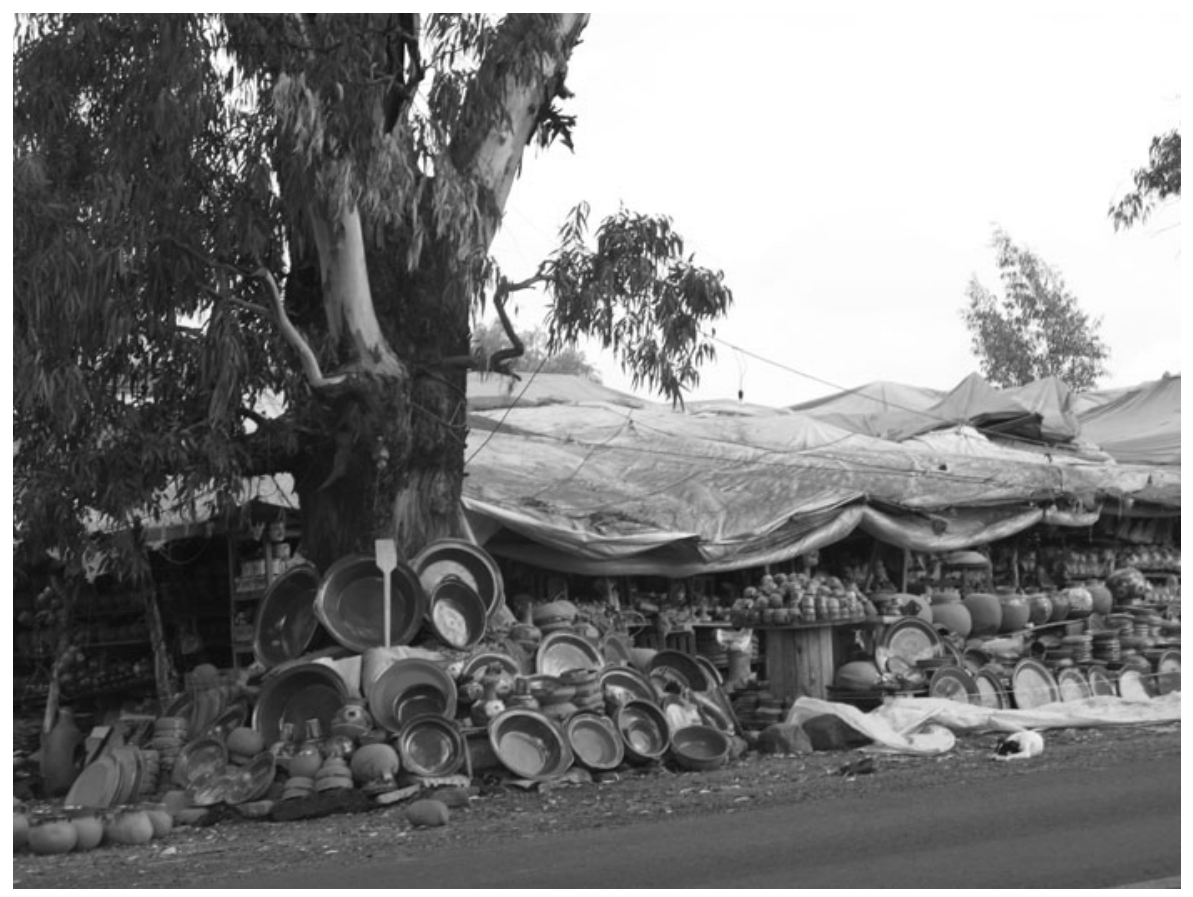

Figure 13. Potters sometimes sell their production to middlemen, who may have shops in town or on the highway near Huáncito (2014). Photograph by author. 


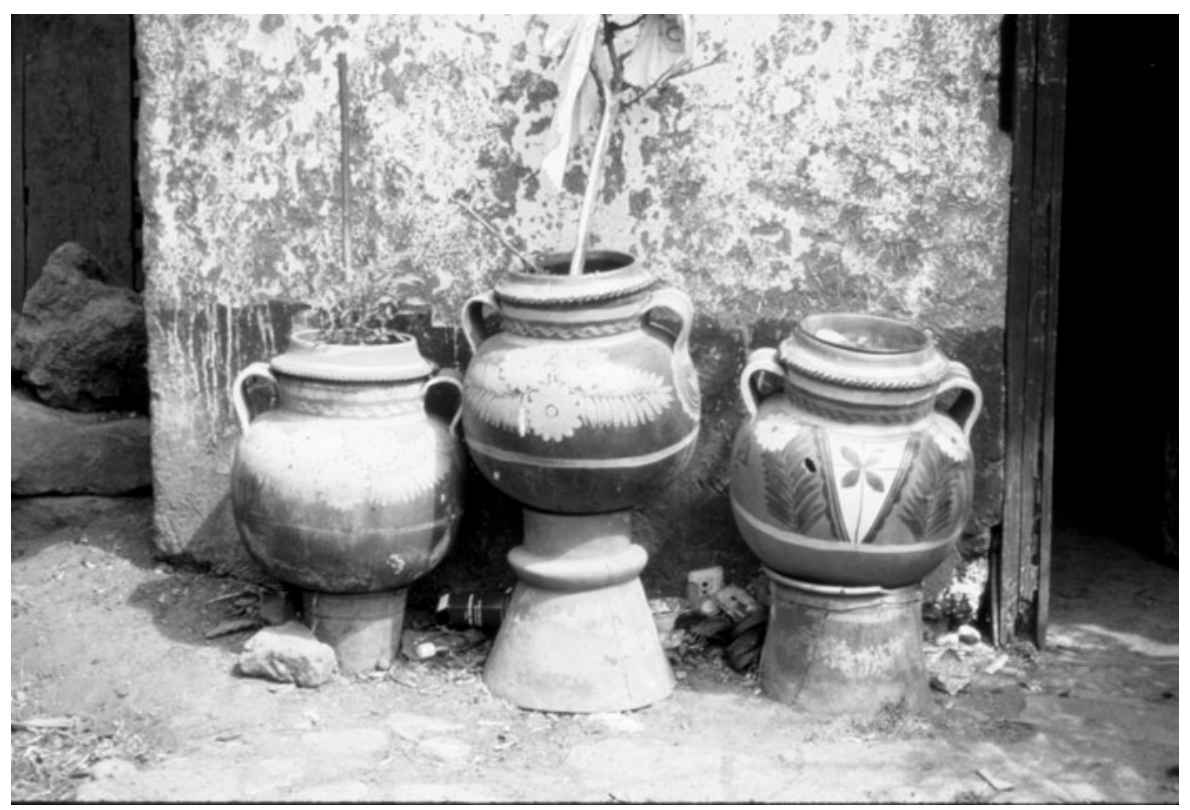

Figure 14. In some households, one can see vessels that are no longer functional and are recycled as flower pots once their use life is over. This custom has obvious archaeological implications (1990). Photograph by author.

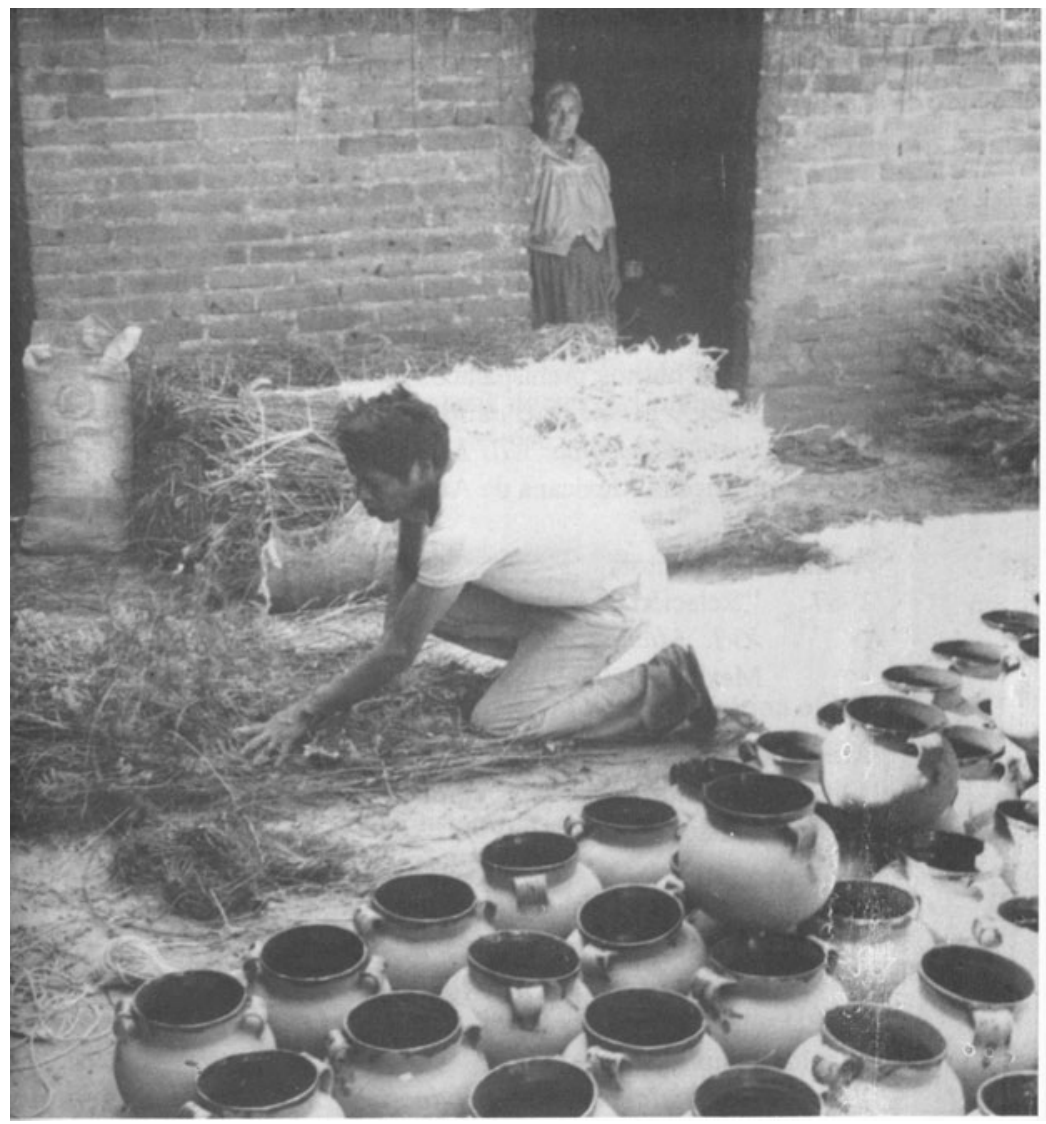

Figure 15. Many potters usually carry their pots in bundles made with sacks padded with twigs and grass for protection when taking them to sell outside of Huáncito (Salomón Espicio household, 1990). Photograph by author. 
made of bricks and mortar rather than adobe. Nevertheless, potters' kilns (probably among the oldest features of the local ceramic industry) have remained with few modifications from ancient times, as a prime example of cultural and technological continuity.

Sugiura (2011:116) states that one frequently hears that potters in general are distinguished from the rest of the people because of a conservative attitude and unwillingness to change, in particular craftsmen and women who make so-called "utilitarian" clay pots linked to basic culinary activities like cooking, transporting, storing and serving food. While doing this research, I was able to witness the process of social change and cultural continuity around a centuries-old craft in a Tarascan community. In the final analysis, the goal of my research is to produce ethnographic information to aid in the interpretation of the archaeological record. This interaction between ethnoarchaeological data and archaeological fieldwork in Michoacán is seen in the work recently carried out by Hirshman (2011) in the Lake Pátzcuaro Basin. By contrasting archaeological information with the relevant ethnographic data, Hirshman and others (e.g., Pollard 2009, 2011a, 2011b) have been able to produce a theoretical model for understanding craft production in the pre-Hispanic Tarascan state. According to this viewpoint, local producers worked in their households, using widely available resources in order to make their vessels and, at the same time, improve their income. The members of certain households could have specialized in an aspect of pottery manufacture, and this activity may have become the economic mainstay for many families (Hirshman 2011:218).

By studying the environmental factors that impinge on ceramic production, such as weather patterns, and the availability of natural resources such as clay, water, and firewood, we can have a whole perspective of the ceramic complex, something that is not possible in the archaeological context. Ethnoarchaeological research of ceramic production in a systemic context, usually in "traditional" societies, provides the kind of information we need for placing pottery manufacture, as well as other crafts, in their entire cultural setting, taking into account all sociocultural aspects linked with this technological tradition.

\section{Pottery Manufacture and the Use of Domestic Space}

This section deals with the organization of domestic space in three households in Huáncito where ceramic production is the main activity. The organization of domestic space has received attention from a number of archaeologists for a long time (see examples in P. Arnold 1991, 2005; Binford 1983, 1986; De Lucia 2013; De Lucia and Overholtzer 2014; Douglass and Gonlin 2012; Flannery 1976, 1986; Kent 1984, 1990; Metcalfe and Heath 1990; Simms and Heath 1990, among many others). The goal of defining the spatial structure of the archaeological record and the activities that were performed in a site cannot be fulfilled solely by archaeological research (i.e., excavation), however, because archaeological facts are static, and in themselves lack the information we need to interpret the dynamic aspects of culture. In the case of ceramic production in the pre-Hispanic era, the information we have about the use of domestic space is rather limited, since extensive excavations of pottery-producing households are few and far-between (see Canto Aguilar 1986 for an explanation of this problem). This lack of information is particularly evident in Western Mexico.

Kent (1990:1) said the following about this situation in Mesoamerican archaeology: "[a]rchaeologists... have tended to work in discipline isolation. They have neglected the research and therefore the insights obtained in other disciplines confronting similar problems." In her book Domestic Architecture and the Use of Space, Kent (1990:1) demonstrates "how an archaeologist can use the other disciplines' data and theories in a productive manner." Kent's book investigates "the relationship between architecture and the use of space... around the world and through time."

The relationship between the fragments of matter that archaeologists find in the field and the cultural phenomena responsible for their creation is not always obvious; therefore, we need more studies of the formation processes of archaeological contexts, of the use and organization of domestic space, of the structure and functioning of households, and of activity areas in general. These studies should include ethnographic observations in contemporary communities, with the goal of obtaining middle-range information that would help us in the interpretation of the processual aspects of human behavior from the artifacts and their spatial associations.

This study seeks to increase our knowledge and understanding of the spatial context or activity areas in ceramic-producing households. The activity-area concept has gained a great popularity in the archaeological literature since the 1970s. According to Flannery and Winter (1976), this concept refers to a spatially restricted area where a specific task (or cluster of interrelated tasks) has taken place. An activity area is usually characterized by an accumulation of tools, discarded products, or raw materials. Even in the cases where no activity areas are identified, many archaeologists in Mesoamerica have recognized "tool kits" used for specific tasks (Flannery and Winter 1976:34).

For Flannery (1976:5), the smallest unit of analysis in a pre-Hispanic village is the activity area, comparable with an element that includes non-moveable features such as fire hearths or storage pits. In the next level of complexity, we could add those portions of a house floor that usually consist of several elements or activity areas, integrating the gendered work areas inside the household. The next unit of analysis is the house itself, to which we could add the household cluster (i.e., the house plus all the features found immediately around it, such as storage pits, burials, and others that can be linked to the same domestic structure). According to Manzanilla (1986:9), an activity area "is the basic unit of analysis of the archaeological record, because it is a reflection of specific and repetitive actions, with both a social character and a specific functional basis."

Nevertheless, the activity area concept in archaeology has not been free of criticism. One of the most vocal critics is O'Connell (1987), who says that most analyses and interpretations of spatial patterns have been based on three assumptions: (1) activities are spatially segregated, that is to say that each activity or cluster of mutually linked activities is restricted to its own space or cluster of spaces within a site; (2) most activities typically produce "tool kits", or groups of artifacts which are characteristic to each activity and vary accordingly, or physical residues in proportion to the frequency of execution of a given activity; and (3) artifacts and residues associated with a specific activity are deposited at, or very near, the place of execution.

All these assumptions have been questioned by recent ethnoarchaeological research, which has shown that: (1) different activities are frequently executed in one place, and conversely one same activity can be carried out in different places within a site, depending on such factors as the composition of group works, the number and kind of activities performed simultaneously, climatic conditions, and the distribution of shade or shelter inside the house; (2) many activities do not necessarily produce co- varying clusters of 
artifacts in proportion to the frequency of execution; and (3) residues produced by a specific activity are not necessarily deposited in the place of production; frequently they are reordered according to parameters that are not linked to the activity that produced them, and may be moved differentially to another locality to be discarded (O'Connell 1987:74).

Kent (1984) came to similar conclusions in her ethnoarchaeological study of activity areas by informants pertaining to three distinct ethnic groups: Navajos, Spanish-Americans, and Euro-Americans. Kent tested three hypotheses, namely that activity areas can be discerned from the content and spatial arrangement of artifact (and other) remains; that most activity areas are gender-specific; and that in most activity areas only one function is performed. The first assumption was confirmed by Kent's data, while the other two were not (Adams 1987:105).

In conclusion, the relationship between cultural behavior and its reflection in the archaeological record is apparently much more complex than one might think. On the other hand, the organization of space is a systematic affair, and so it should be represented in systematic patterns in the archaeological record. Therefore, we should ask ourselves the following questions: can we identify and describe the factors that shape the organization of behavior within sites? Can the knowledge of their operation be used in investigations about the archaeological record, and in the reconstruction of ancient behavior? These questions can be answered through ethnoarchaeological research, by the following means: (1) direct observation of modern behavior, especially how a material (i.e., archaeological) record is formed; (2) developing hypotheses to explain the relationship between behavior and material contexts; and (3) testing the hypotheses under different conditions, again in situations where both the cultural behavior and its archaeological consequences can be directly seen (O'Connell 1987:75).

What follows is a discussion of the organization of domestic space in three households in Huáncito where the production of pottery is the single most important economic activity that shares domestic spaces with other day-to-day activities performed by all members of the household, such as cooking, eating, sleeping, washing, relaxing, and so on. The objective of this research is to find out to what extent the activity-area concept can be sustained in the light of the "ethnographic reality" of the case under discussion.

Two families are mentioned above (Fidel Lorenzo and Isaac Cayetano), while the third household, pertaining to Salomón Espicio and his family, is very similar in all respects to the other two, so there is no need for a full description here. The original ethnographic work on which this section is based was carried out in 1991-1992; back then, the three houses were similar to each other in terms of architecture and general layout. They had several rooms around a patio; these rooms were used for sleeping and for storing all kinds of objects, many of them related to potting activities, such as molds, sacks of clay, finished and unfinished pots, and so on. The kitchen is usually in a separate room, and is not only used for preparing and consuming food, but also for many other activities such as making and painting pots. In Fidel Lorenzo's household, food may be prepared and consumed near the kiln, using a small stove made of adobe (Figure 16a). Sometimes food is prepared in the patio outside the kitchen, using an improvised hearth with several rocks directly on the floor (Figure 16b).

The floor of the houses consisted of packed earth, but it was replaced by a cement floor about 10 years ago. Only the most basic furniture was found in most houses: wooden chairs and tables, cupboards, and the like. People used to sleep on woven reed mats (petates) on the floor. The patios have many kinds of fruit trees that give shade while working in the open (Figure 17). All three houses have electrical power, running water, and a latrine.

The portable objects and fixed elements and features linked to pottery manufacture are basically the same in most households in Huáncito: the "work table" (Figure 18) consisting of a thick wooden plank ( $30 \mathrm{~cm}$ wide by $50 \mathrm{~cm}$ long) directly at ground level or at a height of some 50 centimeters; a variable amount of molds, several objects used for polishing pots, such as rags and bits of plastic; kilns for firing the pots (Figure 19), and areas for drying the pots and for storage (Figure 20).

\section{Potting Activities in Spatial Context}

The systematic observations discussed here included all activities inside and outside the potting compounds, and were aided by interviews and by a collection of pottery samples. The information obtained in this part of the study is summarized in Tables 2-4 and Figures 21-23. A photographic record of all relevant activities and features was made during the period of study. This information has been complemented by unsystematic observations in Huáncito and other towns inside and outside La Cañada during many years from the early 1990s up to the present.

Sugiura and Serra (1990:205) conducted a study of the use of space in several potting compounds in the Toluca Valley, arriving at the conclusion that "space is a multi-dimensional, multi-semantic variable that can be approached from several perspectives." For Sugiura and Serra, the first level of approach to the issue of space in archaeology consists in defining and identifying the "functional space", or the area where we think certain specific activities took place. This identification should be based not just on archaeological data about prehistoric contexts, but should also include information on spatial organization in modern communities, such as the data presented below.

Clay Extraction and Grinding. We have already seen that, in Huáncito, the clay beds are on the outskirts of town, so both extraction and grinding of clay are usually carried out outside the households. The clay can also be pulverized in the potter's home, however, as well as sifted to eliminate small stones, twigs, and other "impurities" using a sieve (Figure 24). In addition to the rocks used for pulverizing the clay, potters use metates, similar to the ones used for grinding maize for making tortillas, like the one seen at the right in Figure 18.

Kneading the Clay. Part of the process of making a clay pot consists of adding a little water to the pulverized clay, in order to make a malleable paste in the shape of a big lump or ball. This activity can be performed in the open, for instance in the patio, under the shade of the trees, or inside the house. The clay lumps can be stored for later use inside the house.

Molding the Pots. Once the kneading is finished and the paste is ready, the next step is to put it inside the molds for obtaining the desired shape (Figure 25). This activity is usually performed on the "work table." The table has to be covered by a special kind of fine dust so the clay will not stick to it. Potters in Huáncito use two kinds of molds: the concave vertical-half mold is used for making cántaros, ollas and botellones (water bottles), while the 


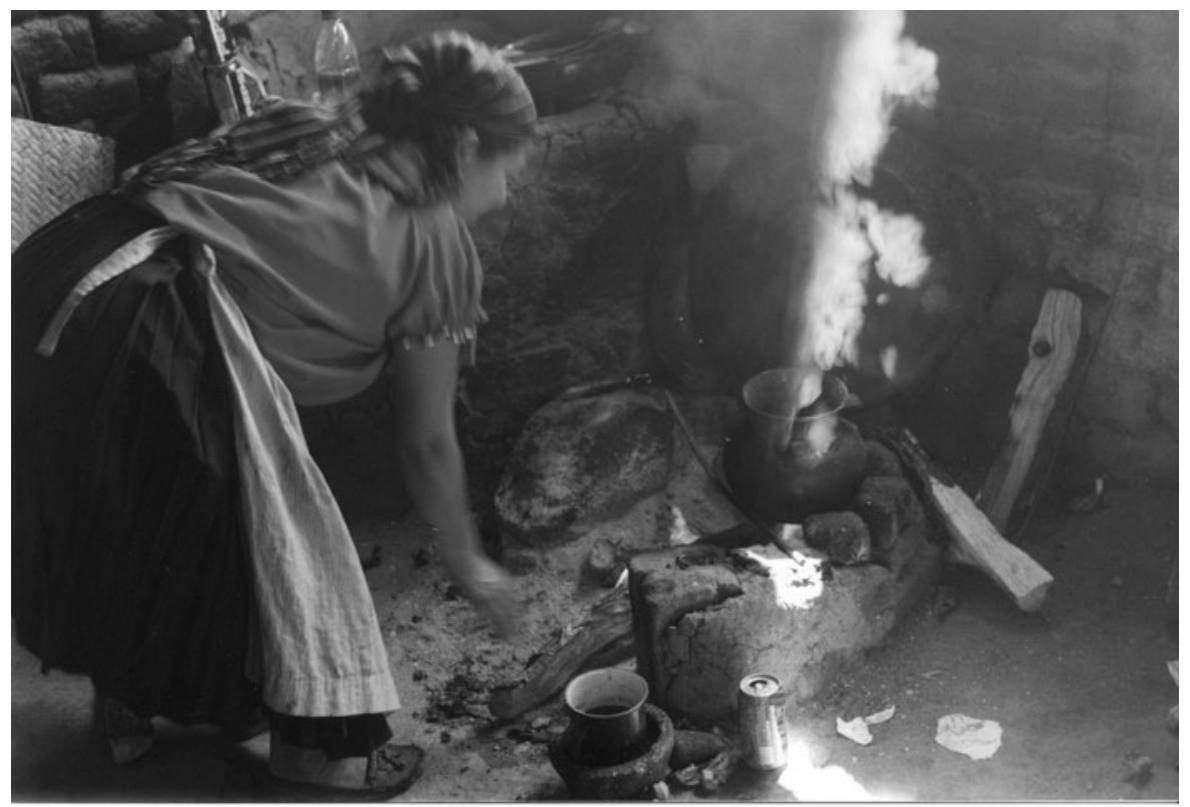

(a)

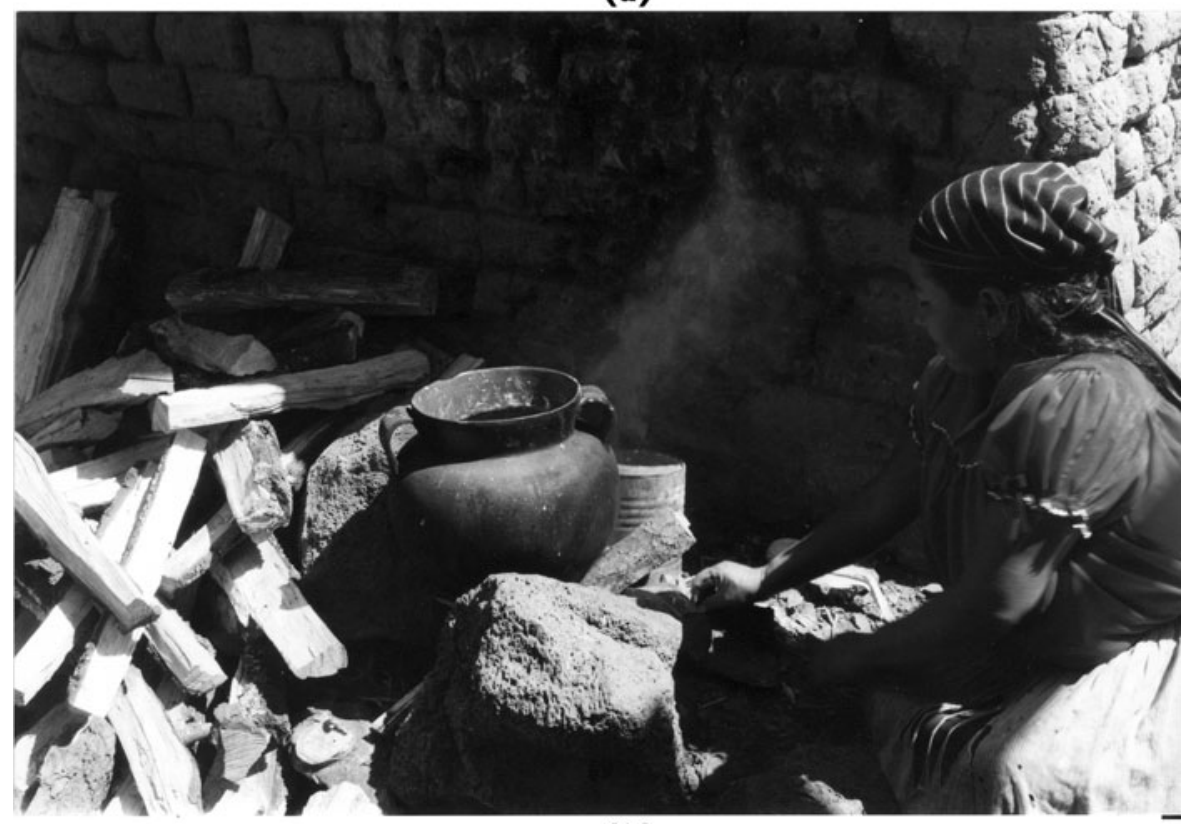

(b)

Figure 16. (a) In Fidel Lorenzo's household, food may be prepared and consumed near the kiln, using a small stove made of adobe. (b) Sometimes food is prepared in the patio outside the kitchen, using an improvised hearth with several rocks directly on the floor (2005). Photographs by author.

convex or mushroom mold is used for making cazuelas (pans) and comales or griddles. These molds are kept in several places inside the houses, so they are not always found in or near the place where they are used.

Smoothing, Polishing and Burnishing the Pots. Once out of the mold, the vessel is smoothed with a piece of wet cloth; this way the mold scars are erased, as well as any imperfection on the surface of the still-fresh vessel. After the charanda slip is added, the pot is polished or burnished with a fragment of plastic until it is shiny (in ancient times a small fine-grained river cobble was used;
Figure 26). These activities can be performed in virtually any space inside the house, for instance under the shade of a tree in the patio, or inside one of the rooms, especially in case of rain. Sometimes the potters perform this task while watching television.

Drying the Pots. After polishing the pots they are put in a room to dry, which may be dedicated exclusively to that task (in the case of Salomón's house), or in one of the bedrooms. It happens sometimes that space for sleeping in a room is minimal on account of all the pots stored there for drying. Before putting the pots into the kiln, they are further dried in the open, usually in the patio (Figure 27). 


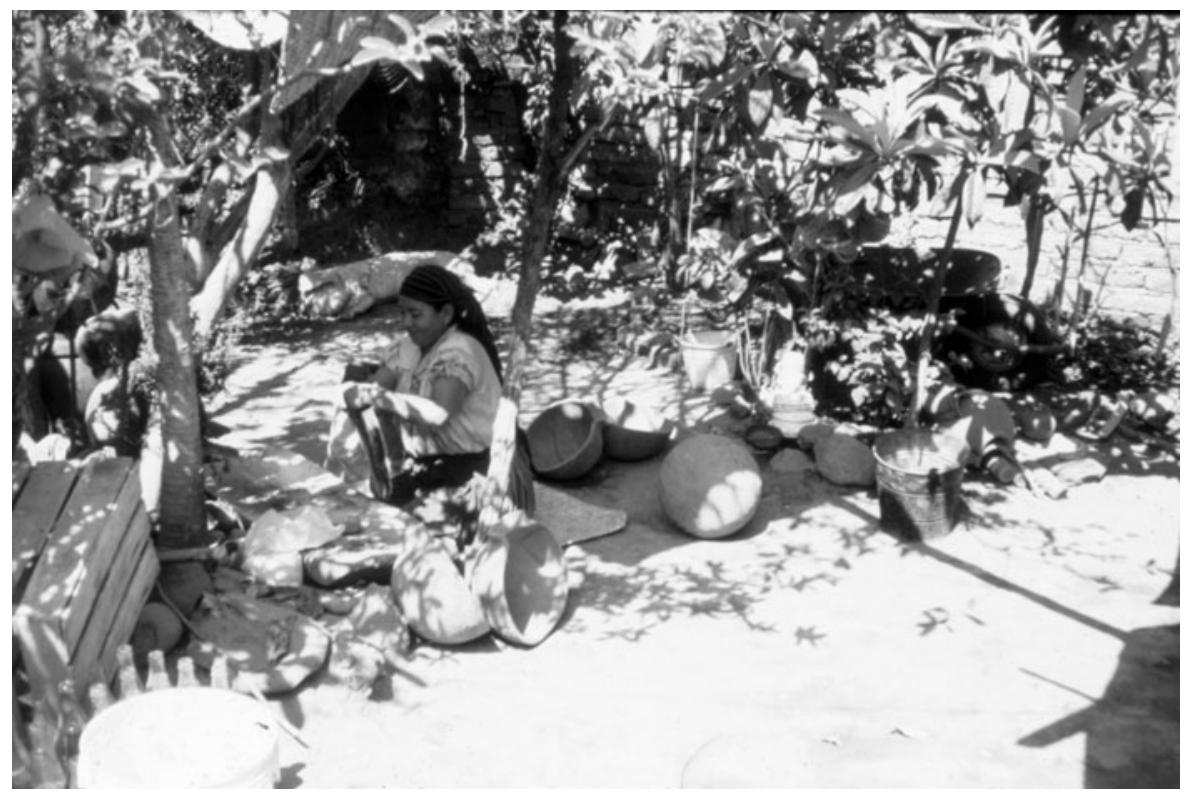

Figure 17. The patios of many houses in Huáncito have several fruit trees and other plants that give shade while potters are working in the open (Fidel Lorenzo household, 1990). Photograph by author.

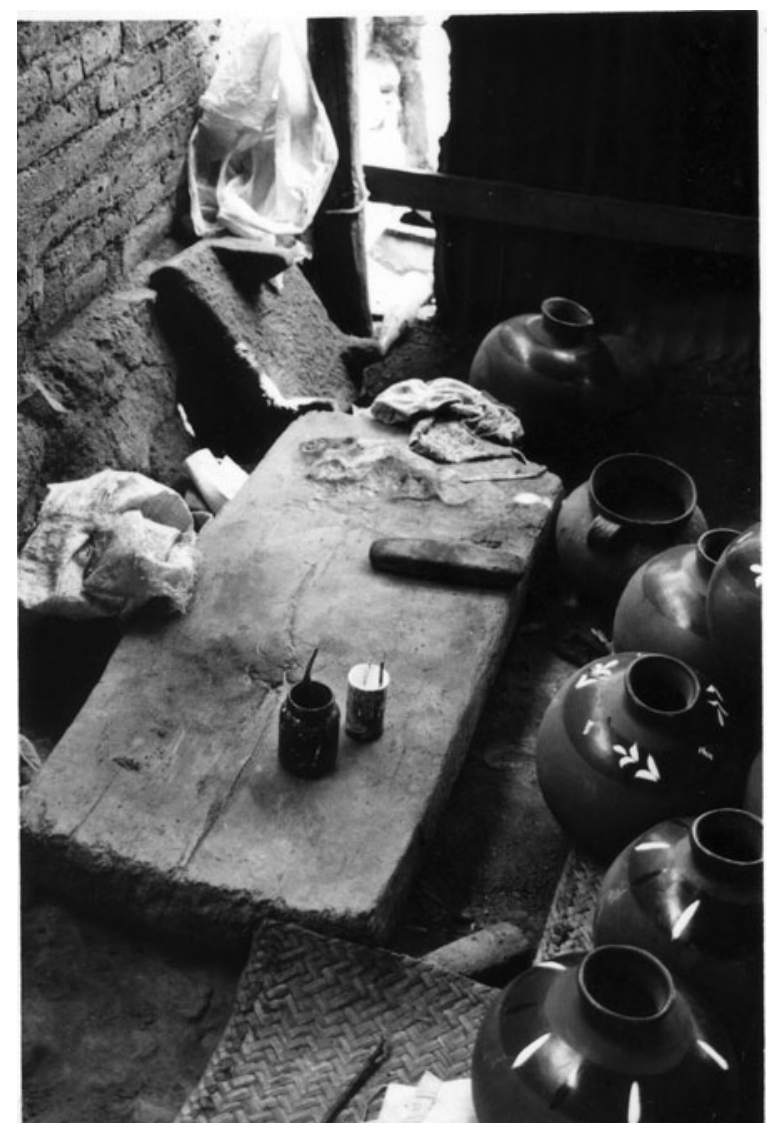

Figure 18. The "worktable" found in many houses in Huáncito consists of a thick wooden plank (30 $\mathrm{cm}$ wide by $50 \mathrm{~cm}$ long) directly at ground level or at a height of some $50 \mathrm{~cm}$. This figure shows a worktable in use. Note the pots around it, the paint containers on the table, the stone mano used for flattening the clay before putting it into the mold, and the metate in the corner used for grinding the clay (1990). Photograph by author.
Potters try to use the area of the patio with less traffic in order to avoid accidents, but this is not always possible on account of dogs and children.

Firing Pots in the Kiln. Of all the processes involved in making clay objects, firing is of the utmost importance, because this is how vessels, figurines, roof tiles, and other items become hard and strong enough to perform their function successfully. We have already seen that, in Huáncito and most other areas where pottery is made, the kiln is the feature where firing, the most crucial activity, takes place. The kiln is usually located in the patio, although in many instances kilns are constructed indoors.

Fuel for firing the kiln is frequently stored in the potter's home, or has to be procured just before using the kiln. The top of the kiln is covered by broken pots, called "wasters," and comales (griddles), usually kept near the kiln (Figure 28). Such a concentration of broken and burned potsherds, in addition to the kiln itself, would be an archaeological correlate or marker for pottery production.

Pottery is still fired in the open, without using a kiln, in several Tarascan towns, such as Zipiajo in the Zacapu Basin (Figure 29), some 40 kilometers east of La Cañada. Firing in the open may produce chemical alterations in the soil, which together with burn stains and ash concentrations would remain as archaeological markers for this activity (Barba 2016; De Lucia 2013).

Painting the Pots. This is one of the activities we have seen in many Huáncito households with less restriction in terms of the areas where it can be performed. The part of the house where pots are painted depends on variables such as weather, available shade and space, and other activities being carried out at the same time. When the climate is dry, potters prefer to paint in the patio under the shade of a tree, although it is also common to use the kitchen or one of the rooms (Figure 30). 


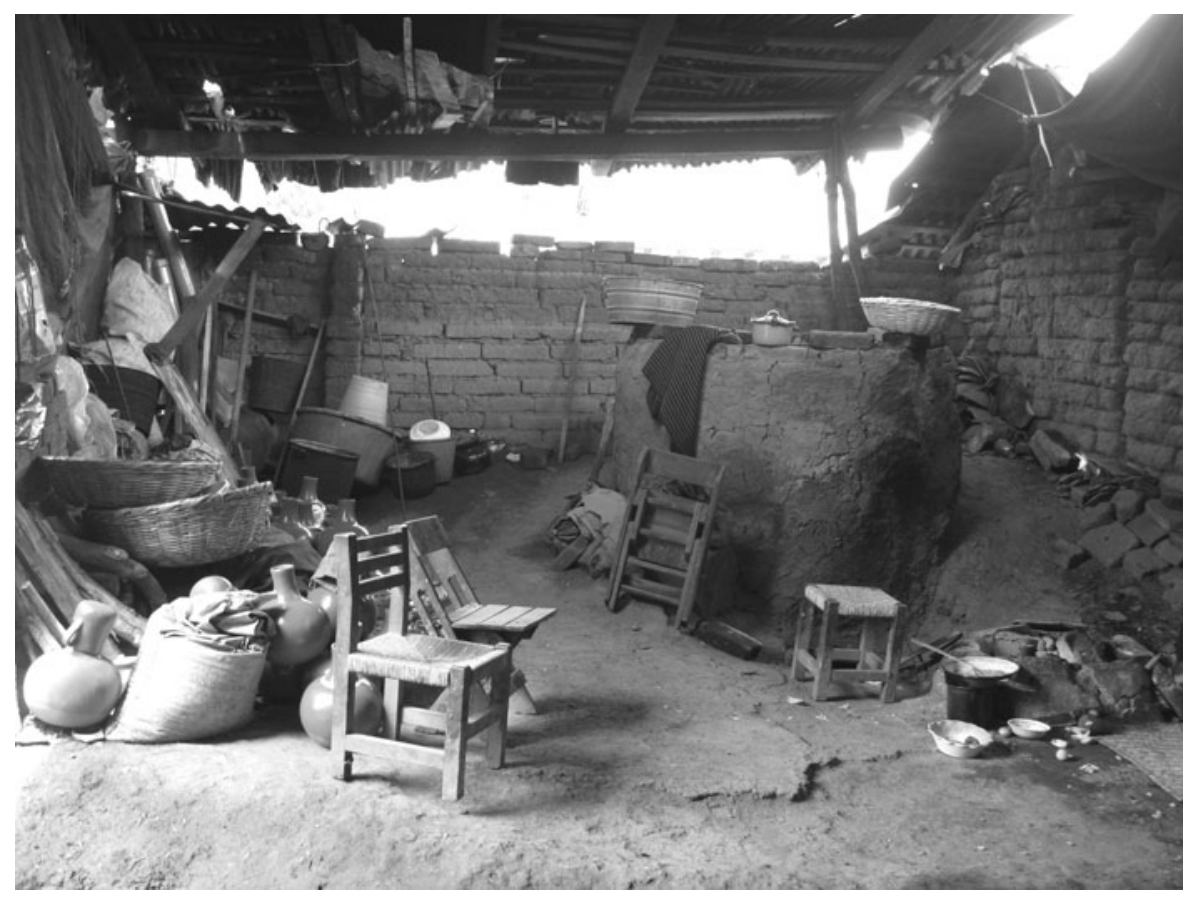

Figure 19. In Fidel Lorenzo's home, the room where the kiln is located is used as a de facto storage area, where all kinds of objects are kept in a somewhat chaotic arrangement. Note the remains of a meal near the hearth in the lower right-hand corner (2014). Photograph by author.

Discard of Broken or Defective Products. Although most potters in Huáncito are quite skilled and usually do not encounter any problems when firing the kiln, it is not uncommon for some vessels to break or to be found to be defective (i.e., pots with thin walls, with smoke stains, warped, cracked, or otherwise malformed) during or after firing. If all these defective pots were left in the kiln's vicinity, in time the area would be full of discarded material. We have seen that lower quality or "second class" pots can be sold cheaper than the rest, while the pots that are totally useless or broken beyond repair are discarded outside the house (Figure 31).

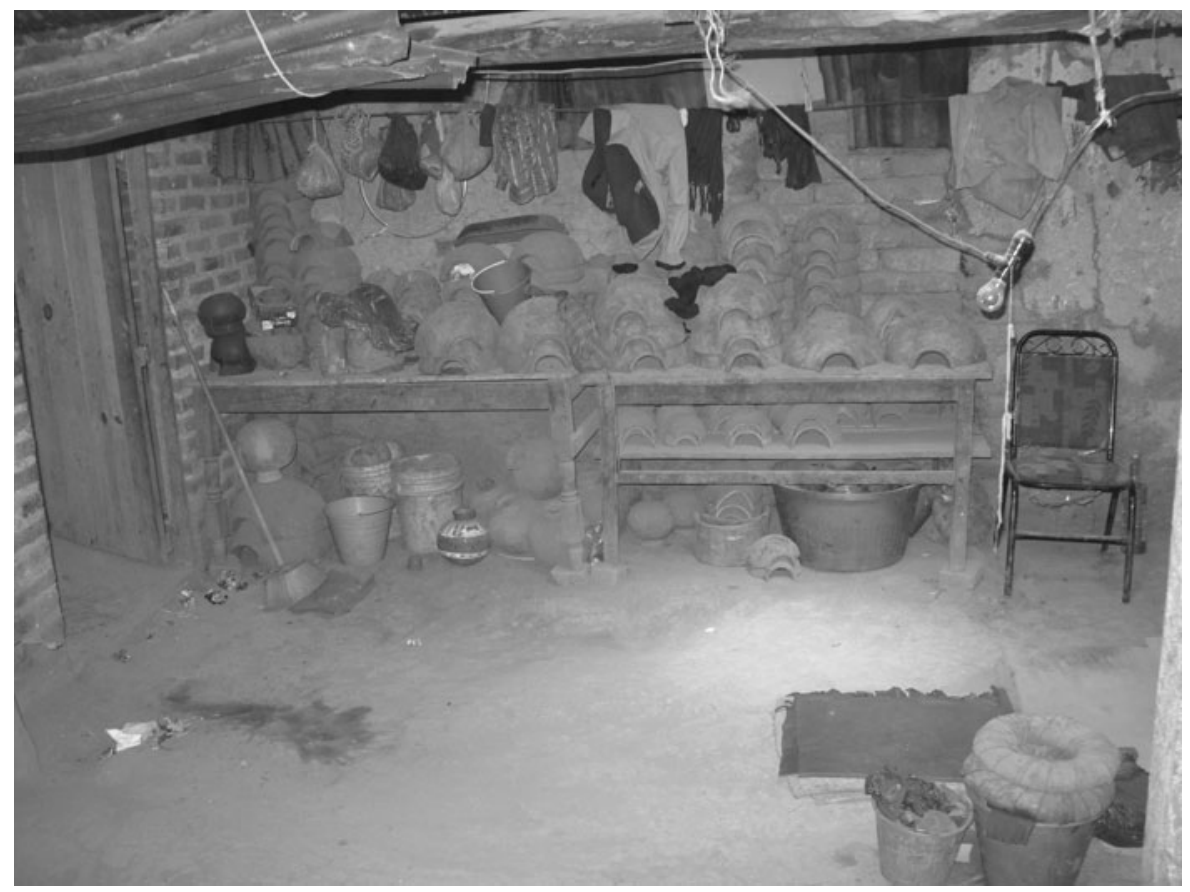

Figure 20. A storage area in Isaac Cayetano's house is used to store many items used in the ceramic process. Here we see pots, molds, and plastic buckets (2014). Photograph by author. 
Table 2. Distribution of activities in the Fidel Lorenzo household. "Storage" refers to clay, fresh (i.e., unfired) pots, finished pots, firewood, and molds.

\begin{tabular}{|c|c|c|c|c|c|c|c|c|}
\hline & Patio & Kitchen & Storage area & Kiln & Worktable & Bedroom & Abandoned room & Outside of house \\
\hline Clay procurement & & & & & & & & $\mathrm{x}$ \\
\hline Grinding & & & & & & & & $\mathrm{x}$ \\
\hline Kneading & $\mathrm{x}$ & $\mathrm{x}$ & & & $\mathrm{x}$ & & & \\
\hline Molding & & & & & $\mathrm{x}$ & $\mathrm{x}$ & & \\
\hline Smoothing & $\mathrm{x}$ & $\mathrm{x}$ & & & & & & \\
\hline Polishing & $\mathrm{x}$ & $\mathrm{x}$ & & & & $\mathrm{x}$ & & \\
\hline Burnishing & $\mathrm{x}$ & $\mathrm{x}$ & & & & $\mathrm{x}$ & & \\
\hline Drying & $\mathrm{x}$ & & & & & $\mathrm{x}$ & & \\
\hline Firing & & & & $\mathrm{x}$ & & & & \\
\hline Painting & $\mathrm{x}$ & $\mathrm{x}$ & & & $\mathrm{x}$ & & & \\
\hline Storage & $\mathrm{x}$ & & $\mathrm{x}$ & & & & & \\
\hline Discard & & & & & & & $\mathrm{x}$ & $\mathrm{x}$ \\
\hline
\end{tabular}

There are two spots on the outskirts of Huáncito where these rejects are discarded, near a river and in a gully (Figure 32), where one can see great concentrations of potsherds. These discard patterns would have obvious archaeological implications for the identification of pottery-producing households.

Most potters eat in their homes during the day, a basic diet primarily of maize tortillas, beans, chili peppers, and squash. Meat is consumed on special occasions, such as the Day of the Dead (November 1 and 2), a ritual celebration when a chili broth called churipo is made with corundas (maize tamales), vegetables, and beef. On a daily basis, meals are eaten in the house, near the kiln in the case of Fidel's house. A small adobe stove has been built for cooking in that area (Figure 33). One would expect that a greater number of pottery items, such as cooking pots, water jugs, serving dishes, glasses, cups, etcetera, would break in this area over time than in the rest of the house. Some of these potsherds would perhaps remain in the archaeological record for future archaeologists to find.

\section{ARCHAEOLOGICAL CORRELATES}

In order to understand the spatial organization of different activities linked to the process of manufacture of clay objects in the pre-Hispanic period, one should be able to recognize not only the tools or artifacts used by potters to carry out the different tasks involved in their daily work, but one should also be able to recognize the raw materials, the locales of production, and of storage of tools and raw materials, like clay (Deal 1988:113). There are two basic problems, however: first, most of the tools and artifacts used in ancient times in potting activities were probably of a perishable nature, therefore it would be difficult to find them in the archaeological record. These items probably included twigs and branches, corncobs, maguey fibers, and textiles. Secondly, there are some items that, although they may be preserved in an archaeological site, would be difficult to identify as potters' tools: stone polishers, shells, grindstones such as metates, manos (Figure 34), and molcajetes (mortars), and the rocks used for pulverizing clay (Canto Aguilar 1986:48-49).

Obviously, not all activities that form part of the ceramic process have the same possibility of representation in the archaeological record, and this should be taken into account when excavating an archaeological site, as shown in the case of a pre-Hispanic household excavated in Xaltocan, a site in the Basin of Mexico (De Lucia 2013:Figure 3). For instance, the extraction of clay could be accomplished with implements as simple as sticks and baskets or sacks, when the clay deposit is near the surface. Picks and shovels would be required when the clay has to be extracted from some depth, as is the case in Huáncito.

I have mentioned that clay grinding was performed using big rocks and grindstones (metates) before the introduction of mechanical mills in Huáncito. Although in some cases this activity might leave some traces, such as calcite grinding for temper (Deal

Table 3. Distribution of activities in the Isaac Cayetano household. Storage refers to clay, fresh (i.e., unfired) pots, finished pots, firewood, and molds.

\begin{tabular}{|c|c|c|c|c|c|c|c|c|}
\hline & Patio & Kitchen & Storage aea & Kiln & Worktable & Bedroom & Area in front of rooms & Outside of house \\
\hline Clay procurement & & & & & & & & $\mathrm{x}$ \\
\hline Grinding & & & & & & & & $\mathrm{x}$ \\
\hline Kneading & $\mathrm{x}$ & & & & & & & \\
\hline Molding & & & & & $\mathrm{x}$ & & & \\
\hline Smoothing & & & & & & & $\mathrm{x}$ & \\
\hline Polishing & $\mathrm{x}$ & & & & & & $\mathrm{x}$ & \\
\hline Burnishing & & & & & & & $\mathrm{x}$ & \\
\hline Drying & $\mathrm{x}$ & & & & & $\mathrm{x}$ & & \\
\hline Firing & & & & $\mathrm{x}$ & & & & \\
\hline Painting & $\mathrm{x}$ & $\mathrm{x}$ & & & $\mathrm{x}$ & & $\mathrm{x}$ & \\
\hline Storage & $\mathrm{x}$ & & $\mathrm{x}$ & & & & $\mathrm{x}$ & \\
\hline Discard & & & & & & & & $\mathrm{x}$ \\
\hline
\end{tabular}


Table 4. Distribution of activities in the Salomón Espicio household. This household produces mostly utilitarian, undecorated pots, so no burnishing or painting takes place here. "Storage" refers to clay, fresh (i.e., unfired) pots, finished pots, firewood, and molds.

\begin{tabular}{|c|c|c|c|c|c|c|c|c|}
\hline & Patio & Kitchen & Drying room & Kiln & Worktable & Bedroom & Area in front of rooms & Outside of house \\
\hline Clay procurement & & & & & & & & $\mathrm{x}$ \\
\hline Grinding & & & & & & & & $\mathrm{x}$ \\
\hline Kneading & & & & & & & $\mathrm{x}$ & \\
\hline Molding & & & & & $\mathrm{x}$ & & $\mathrm{x}$ & \\
\hline Smoothing & & & & & $\mathrm{x}$ & & $\mathrm{x}$ & \\
\hline Drying & $\mathrm{x}$ & & $\mathrm{x}$ & & & & & \\
\hline Firing & & & & $\mathrm{x}$ & & & & \\
\hline Storage & $\mathrm{x}$ & & & & & $\mathrm{x}$ & $\mathrm{x}$ & \\
\hline Discard & $\mathrm{x}$ & & & & & & & $\mathrm{x}$ \\
\hline
\end{tabular}

1988:117), generally the metates used to grind clay are hardly distinguishable from the ones used in food preparation. Here a microanalysis of remains in the surface of the object used for grinding would be of great help to identify its use (Figure 33). Manzanilla (2009:27) found in her excavations at Teotihuacan an alignment of kitchens where metates displayed maize phytoliths, while the rest of the metates in that part of the city were apparently devoted to craft production: grinding masses of stucco, pigment, fibers, and lacquer. This was revealed by microscopic examination of the artifacts.

Clay kneading is an activity that today is carried out without any tool or artifact, so its level of archaeological visibility is pretty much nil (however, when temper is added to the paste, temper may consist of substances such as volcanic stones, shell fragments, and other similar substances that were processed by grinding and would likely remain in an archaeological context). In contrast with clay preparation, molding the vessels would be easy to see in an archaeological situation, since the molds, both concave and convex, are quite abundant in potting compounds in Huáncito. These molds are made of pottery, so their level of conservation and the probability of entering the archaeological record would be high. I have seen that molds in Huáncito are treated with great care, on occasion being repaired if they break. According to information provided by several potters, it is not rare for them to have molds with as many as 10 or 20 years of continuous use.

Of the two kinds of mold used in Huáncito (concave and convex), only the convex mold was used beyond any doubt in pre-Hispanic times. Because the concave mold may have been known in Peru before the conquest (Bankes 1980), however, its use in Mesoamerica should be considered at least as a possibility (Williams 1995).

I have seen that the potters of Huáncito use such objects as pieces of cloth, plastic, or glass for activities such as smoothing, polishing, and burnishing pots. In pre-Hispanic times, small, finegrained stones may have been used for these activities, such as the ones still used in the Chiapas Highlands (Deal 1988). Like polishing pots, painting them is an activity with little archaeological visibility, because the brushes used are small and not durable (sometimes consisting of little more than sticks with dog or squirrel hairs tied at one end). On the other hand, mineral pigments and colorants are valuable for the potters in Huáncito, so they are stored with care, and this increases their level of archaeological visibility.

Firing the pots is perhaps the activity in the whole ceramic process with the highest probability of appearing in the archaeological record. The potter's kiln always has a prominent place within the household or potting compound, usually in the patio. In addition to the firing structure itself, there are other elements that appear in this part of the process, and that could be identified archaeologically. These are the potsherds used to cover the top of the kiln, already discussed. Other items one could expect to find in the firing area are pots that are rejected for being malformed, misfired, smoke-stained, or having a similar flaw; they would probably enter the archaeological record as trash or discards and would be much more abundant in potting households than in those dedicated to other activities within a settlement.

In summary, the material evidences or archaeological correlates of ceramic manufacture in Huáncito that would be able to remain in the archaeological record (see Table 5) consist of the following: (1) molds; (2) kilns and the broken pots used to cover them; (3) broken or misfired rejects (which remain in the potting compound for a period of time until they are taken away to a dumping area); (3) finished pots stored in the potting compound (usually found in far greater amounts than in households not dedicated to pottery production); (4) pigments, temper, and other minerals used in the ceramic process, such as glaze. Most of the other items used in the ceramic process (work table, brushes, cloths, polishers, and firewood) are of perishable nature, or would be hard to identify in an archaeological situation without some form of analogy.

\section{The Structure of Spatial Organization}

The information presented by Arnold (P. Arnold 1991:100-101, 2005) about potting communities in Los Tuxtlas, Veracruz, is to some extent applicable to the Huáncito case study. According to Arnold, ceramic production can be organized either as a flexible activity, or as one that has a more rigid and restricted structure. This characterization is represented by a continuum of productive activities, with tasks that are flexible in terms of the use of space in one extreme, and restricted in the other. Spatially flexible activities are not confined to a specific place; rather, they can be moved from one place to another according to availability of space. The elastic nature of these activities usually means that they are finished with relative speed and produce few material remains and in a low density.

In order to perform spatially flexible activities, tools and techniques are preferred which do not impede the possible relocation of the activity. The artifacts associated with this kind of activity might include polishing stones, small molds, and cutting tools (i.e., blades, knives, scrapers, and other tools made of obsidian or other stones, such as chert). These tools can be used anywhere 


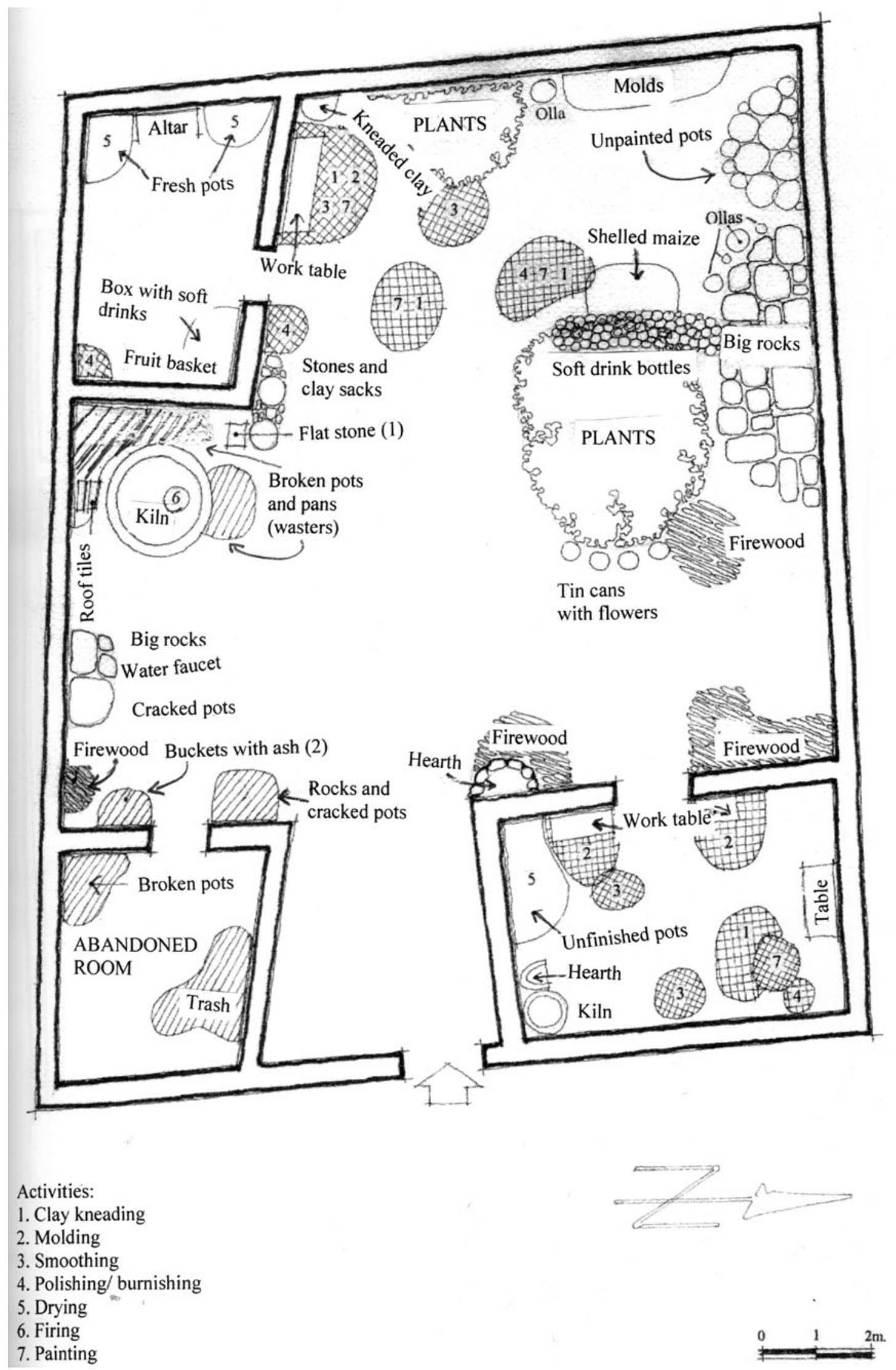

Figure 21. Map of Fidel Lorenzo's household showing activity areas and some elements and features linked to pottery manufacture (1992). Map by author. 


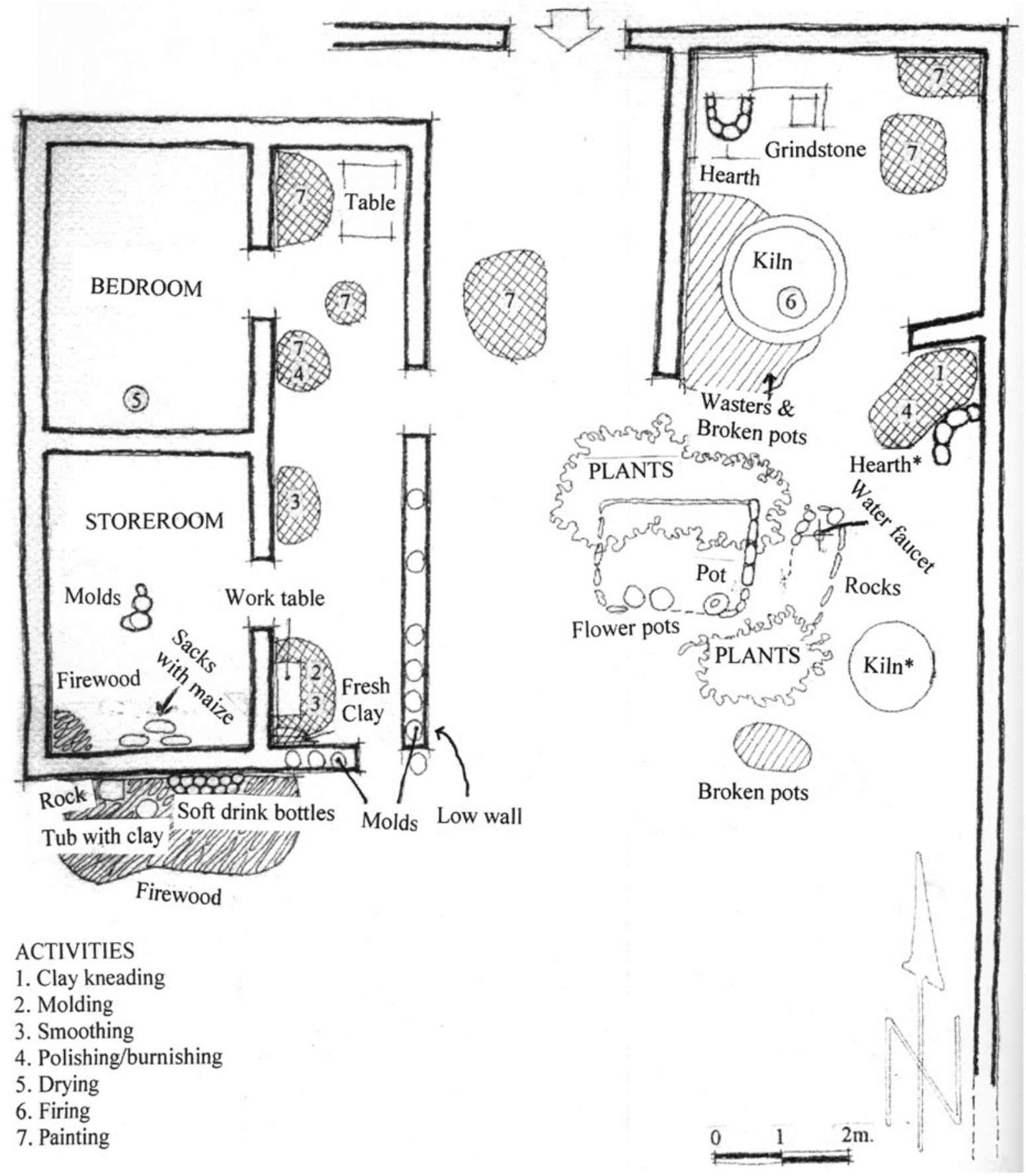

Figure 22. Map of Isaac Cayetano's household, showing activity areas and some elements and features linked to pottery manufacture. An asterisk indicates features that were destroyed by the household members during the course of fieldwork (1992). Map by author.

and can be easily moved with changing conditions that affect the use of space (e.g., sunlight, shade, wind direction, rain, and where the children are playing; P. Arnold 1991).

Spatially restricted activities are linked to different materials and technology than the ones described above. These activities must be performed in a well-defined space, because they depend on a fixed feature, such as the potter's kiln. In comparison with flexible activities, restricted activities usually take longer to perform and produce bigger and more abundant refuse. Other factors that can influence the organization of production are the following: the area available for productive activities (Arnold 2005), the size of the work force, and the sequence in which productive activities are performed (P. Arnold 1991:102).

The ideas expressed by Arnold (P. Arnold 1991) are shared by Sugiura and Serra (1990:212), who say that there are several levels of intensity of production, the lowest being the individual level, in which activity areas linked to pottery manufacture are not fixed or well-defined. In this case, space is multifunctional, and the location 


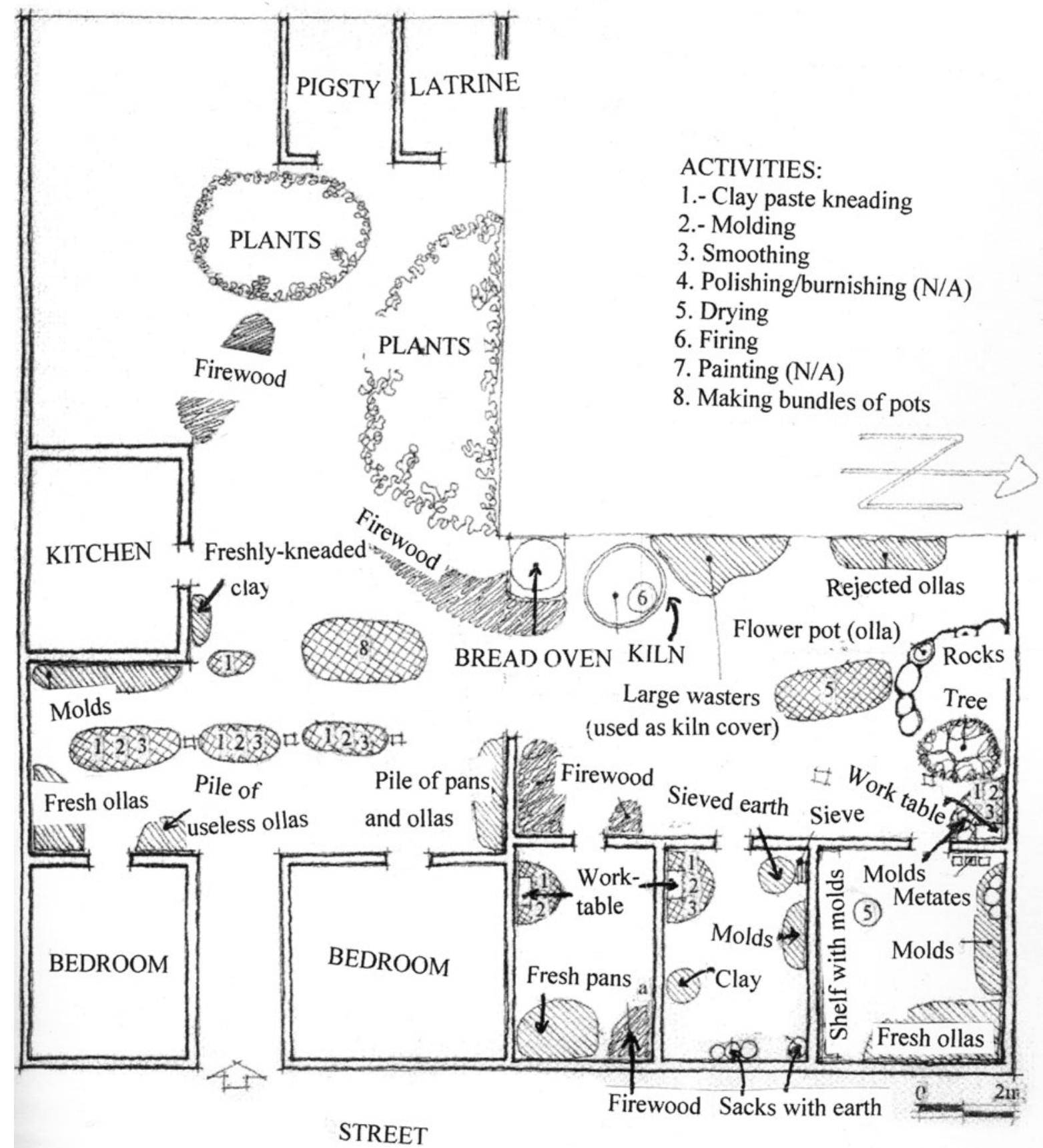

Figure 23. Map of Salomón Espicio's household, showing activity areas and some elements and features linked to pottery manufacture (1992). Map by author.

of some activities (for instance, working with the molds) may change according to the season of the year, the time of day, the weather, or other variables. The use of space in this level of production is disperse and superimposed, like a palimpsest, because spaces are used for multiple purposes, including an endless list of tasks that are not related to pottery manufacture, such as maize processing (shelling, grinding, and boiling), among others.

In the potting households I have studied in Huáncito, most activities linked to pottery manufacture could be defined as "flexible" in terms of the use of space, since there is no particular or exclusive place for each activity (Tables 2-4), excepting those carried out on the work table and the firing of pots in the kiln (see Figures 21-23). Likewise, time is organized in a very elastic manner. Although there is a certain order in which certain actions have to be performed (first the clay has to be extracted from the quarry, then processed by grinding, and the pots have to be smoothened before being polished, and painted before or after firing, according to the kind of paint being used, and so on) certain aspects of production depend on factors outside the control of the potter, such as the weather. In cases when the ideal conditions for making pots are not present, activities are postponed, for instance firing the kiln would not be attempted on a rainy day. 


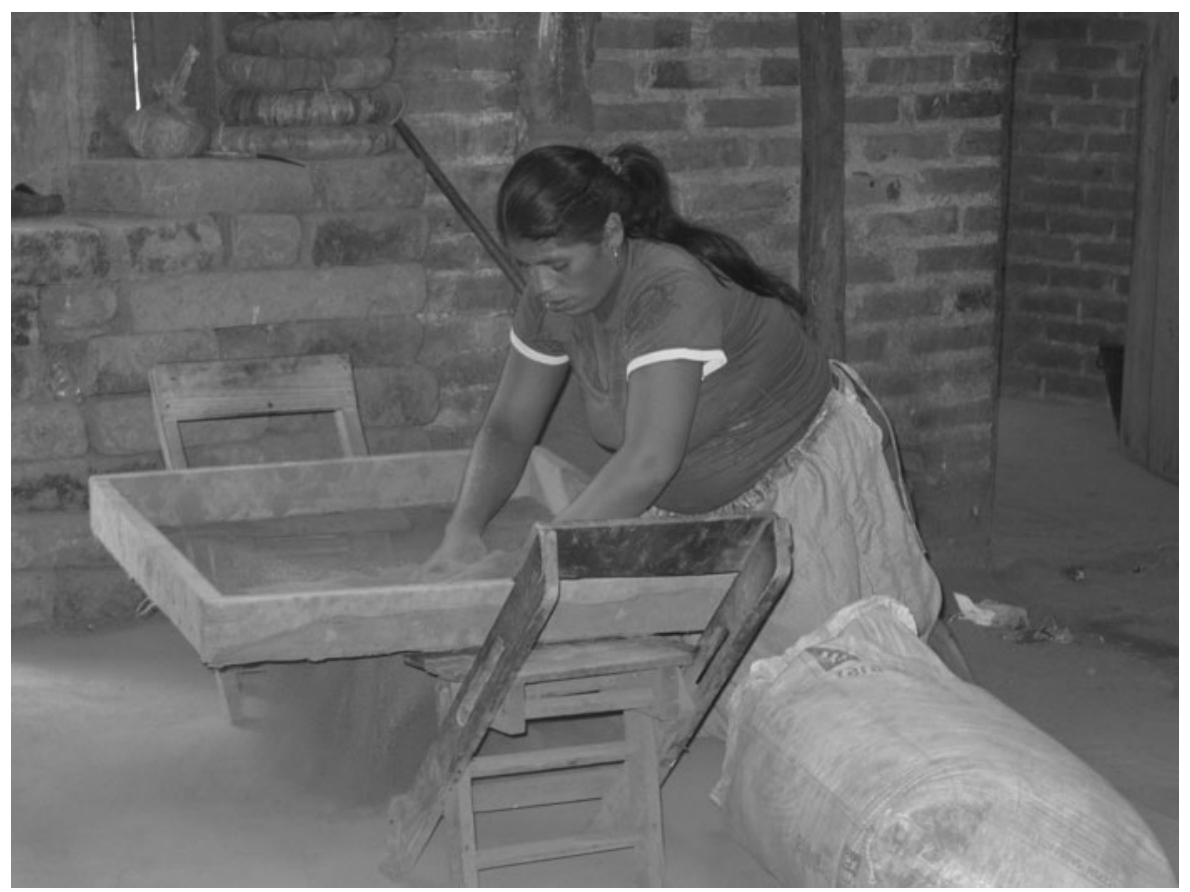

Figure 24. In some cases, the clay must be sifted to eliminate small stones, twigs, and other "impurities" using a sieve (Isaac Cayetano household, 2014). Photograph by author.

\section{Lessons to be Learned about the Use of Domestic Space}

In pottery making, as well as in other production activities, one should differentiate clearly between domestic activities for the household's own consumption, which, in most cases, are performed part-time, and specialized full-time activities that satisfy the demands of the whole community or of some social sectors (Manzanilla 1986:463; see also Feinman and Nicholas 2011, 2012). Most potting households in Huáncito could be defined as specialized workshops, because their level of production far exceeds the needs of the household, and is aimed at trade or exchange. This level of production existed in pre-Hispanic Mesoamerica (Berdan 2014; Rattray 1990:184; Smith 2004, 2016).

According to Gougeon (2012), the majority of activities that occurred at the household level were probably involved in production for domestic needs and consumption. In Gougeon's (2012: 142) opinion, "looking at households as 'black boxes' hides the

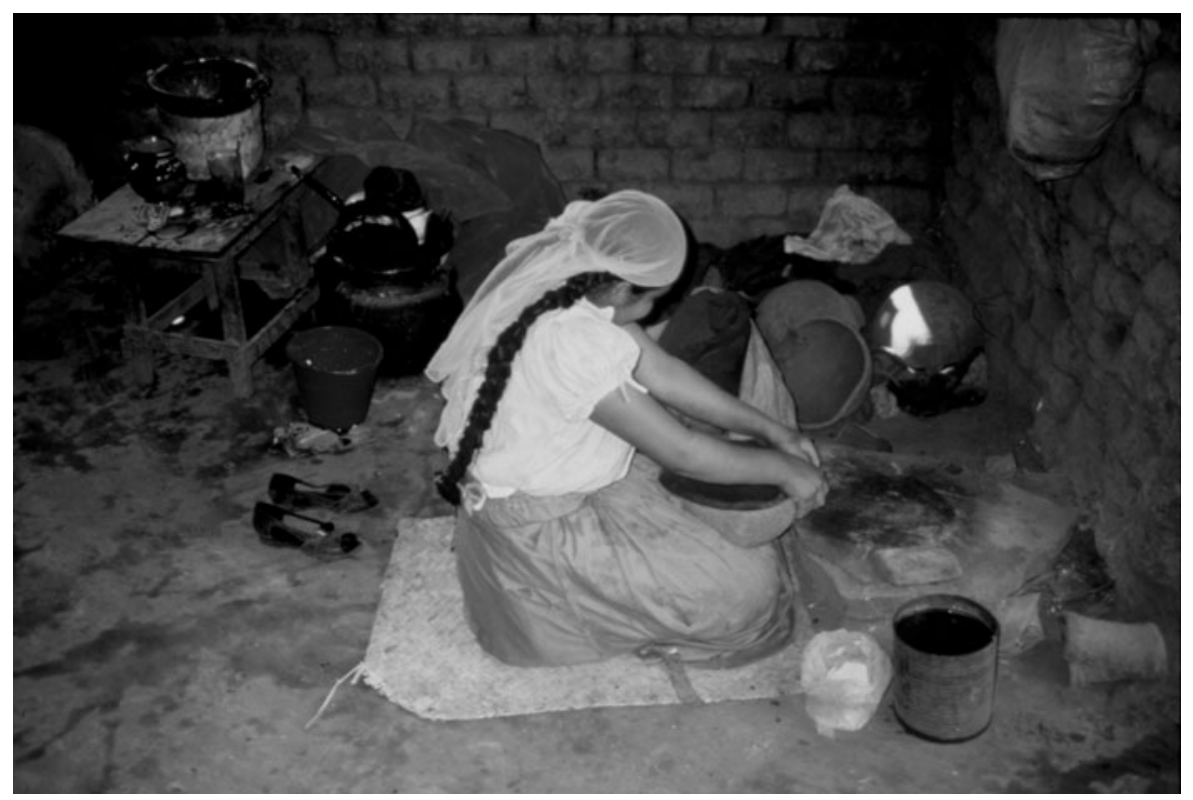

Figure 25. The fresh clay is put inside the molds for obtaining the desired vessel shape. This activity is usually performed on the "work table" or near it, and it requires making a "tortilla" of clay, cutting it down to size, and inserting it into the two halves of the mold (Fidel Lorenzo household, 1990). Photograph by author. 


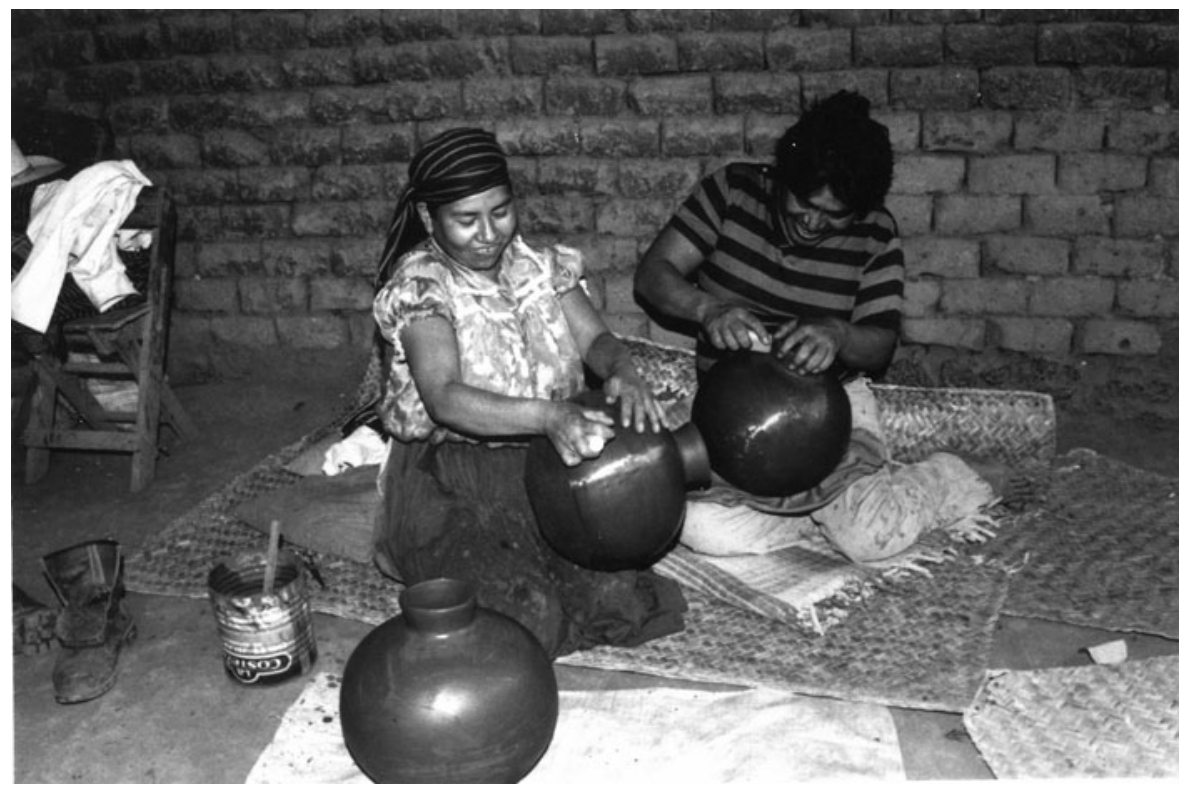

Figure 26. Pots are usually polished with a fragment of plastic until the surface is smooth and shiny (in ancient times a small fine-grained river cobble may have been used for this activity; Fidel Lorenzo household, 1990). Photograph by author.

contributions of the individuals within them[.] It becomes important... when discussing household production to examine the role of the individual. One way of accomplishing this goal is through an examination of activity areas and the division of labor." Households encompass activity groups, "thus, it follows that archaeologists excavate the remains of their activities and the loci of activities. The analysis of activity areas can contribute to studies of household production, consumption, craft specialization, and the... division of activities and space" (Gougeon 2012:142).

Although the organization of domestic space in Huáncito's potting households shows some regular patterns, its analysis following the "activity area" concept presents some challenges due to the fact that most activities are not performed in spatially restricted areas, and are not characterized by an accumulation of tools, discarded products, or raw materials. As we have seen, the activities performed by potters are not consistently carried out in the same place, and several activities can take place in the same spot over time.

According to Sugiura and Serra (1990:208), many studies dealing with activity areas lack any objective beyond the identification of such areas in archaeological contexts, and the "formal description of their functionality." According to Schiffer (1988: 472), although many archaeological studies are based on the assumption that the analyzed artifacts were deposited as primary refuse (i.e., they are found in the place where they were used), this kind of refuse is only produced under certain limited conditions.

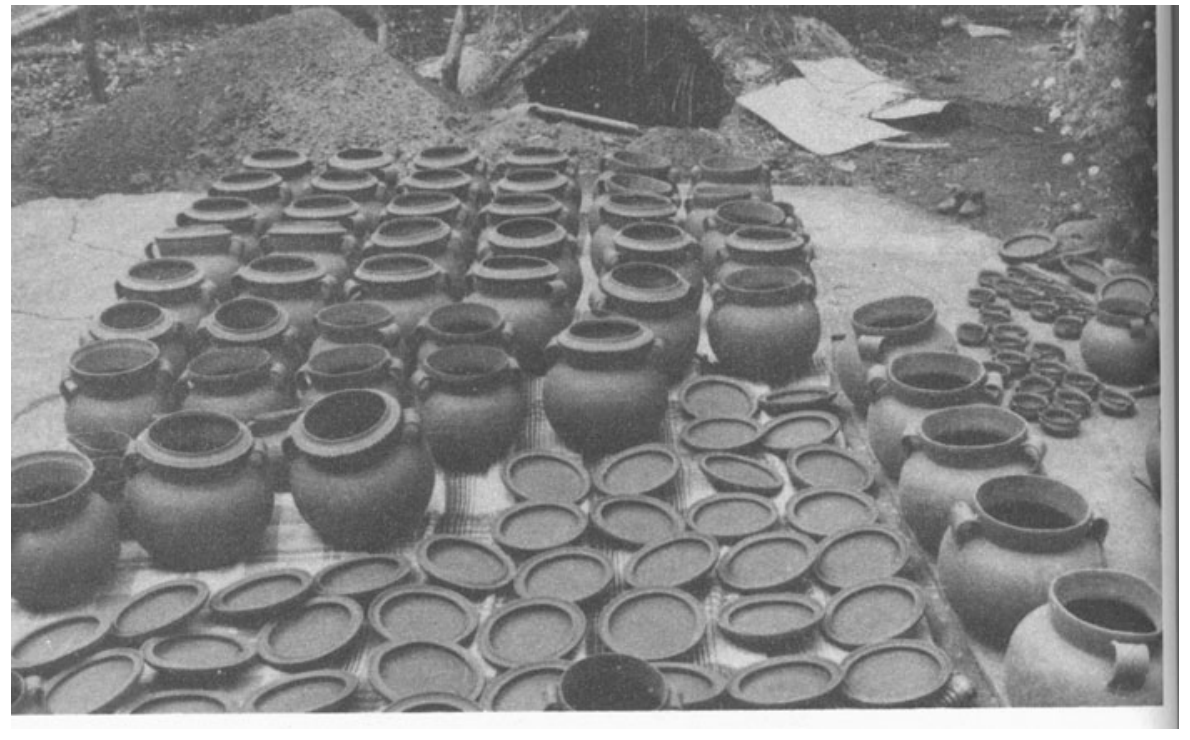

Figure 27. Before putting the pots into the kiln, they are further dried in the open, usually in the patio. Potters try to use the area of the patio with less traffic in order to avoid breakage due to accidents (Salomón Espicio household, 1990). Photograph by author. 


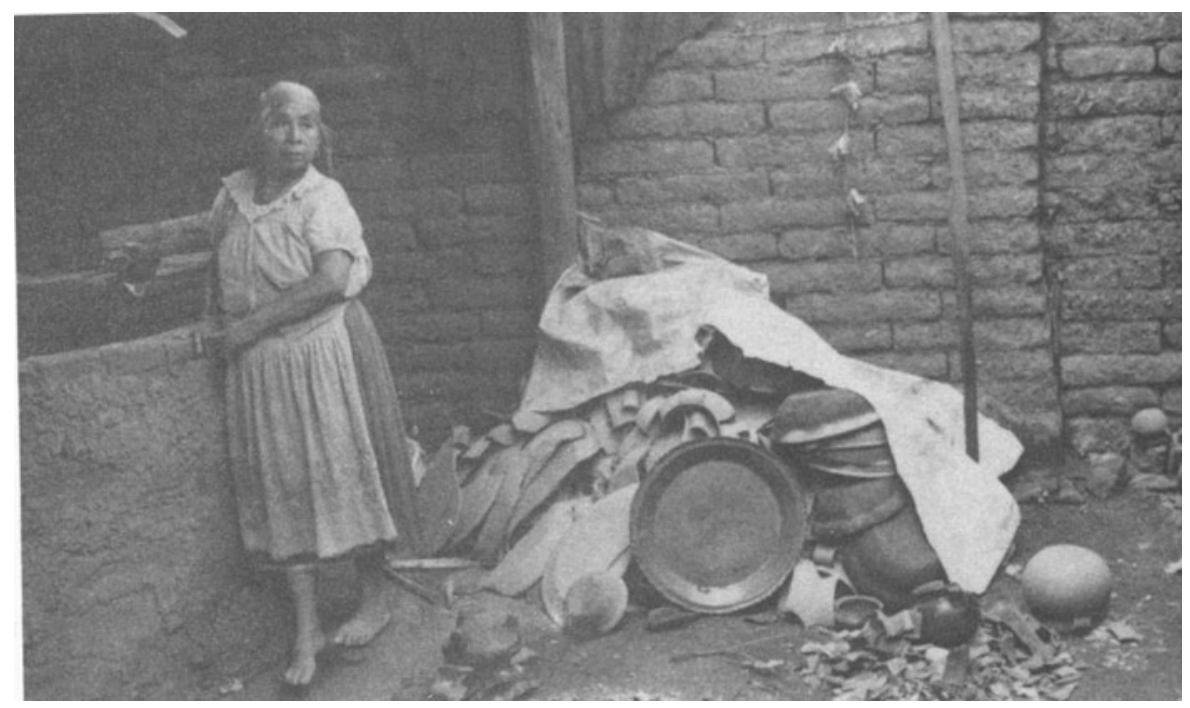

Figure 28. The wasters and comales that cover the kiln during firing are usually kept near the kiln when not in use. Such a concentration of broken and burned potsherds, in addition to the kiln itself, would be a prime archaeological correlate or marker for pottery production (Salomón Espicio household, 1990). Photograph by author.

This has been corroborated by my research in Huáncito, where daily cleaning activities in the houses (especially sweeping the floors in the rooms and the patio) erase the traces left by most activities.

We have seen in these pages that one of the problems for defining activity areas in the case of pottery production is that most of the tools and artifacts used by the potters are small, and can be reused or transported to other settings outside of the place where they were used (see discussion in Stark 1984:12). The "archaeological visibility" of these activities is also affected by the fact that not all activities are consistently carried out in the same space. Obviously, the more frequently one activity is performed in the same spot, the more likely it is to leave material traces or archaeological markers (Table 5) that an archaeologist would be able to recognize as diagnostic features of a certain activity (Deal 1988:113).

Although the present study has not considered a sample of households big enough for obtaining definitive conclusions, it does allow for generalizations about the organization of space in potting households. As one can see in the data discussed above, space in these households is not divided into specific activity areas, and residues of the activities of production are not

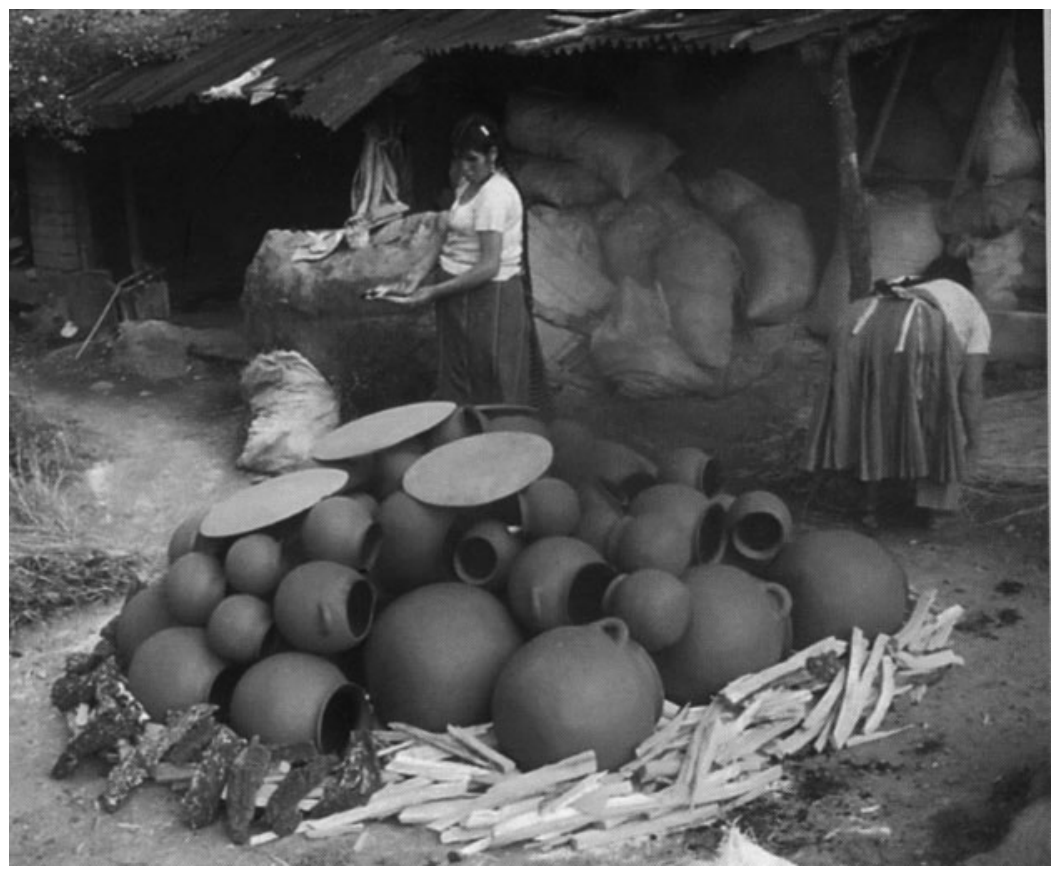

Figure 29. In several Tarascan towns, such as Zipiajo in the Zacapu basin, pottery is still fired in the open, without using a kiln (Elvia Silva Bartolo household, 1995). Photograph by author. 


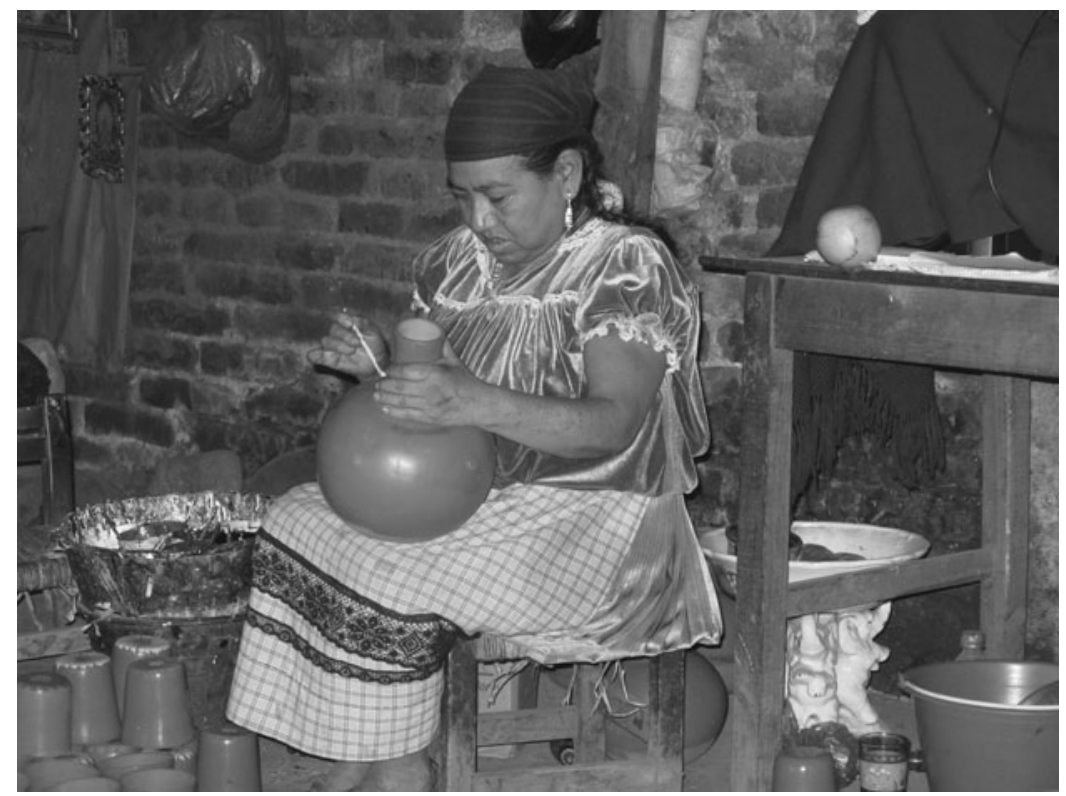

Figure 30. In Huáncito, it is common to use the kitchen or one of the rooms for painting the pots (Fidel Lorenzo household, 2014). Photograph by author.

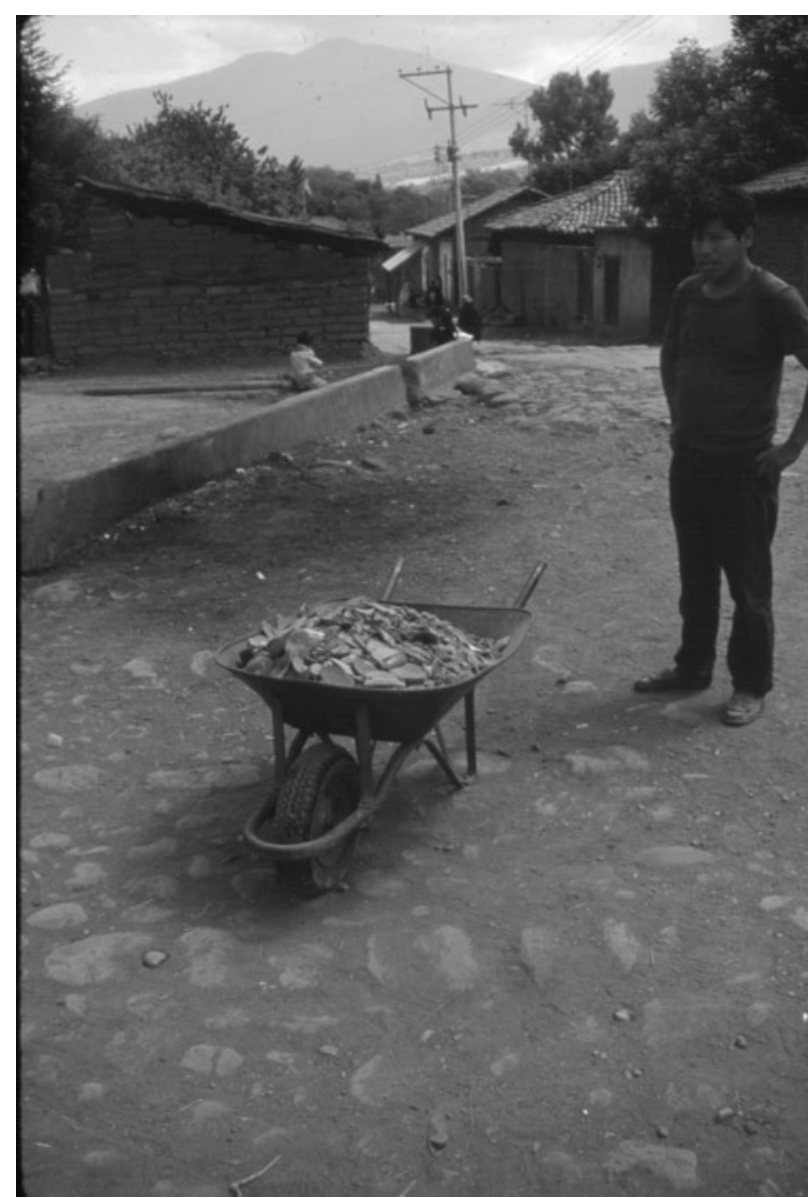

Figure 31. In most potting households, the pots that are totally useless or broken beyond repair are discarded outside the house. In this case, a wheelbarrow is used to transport the potsherds to the dumping area (1990). Photograph by author. deposited in primary contexts, i.e., in or near the spot where the activity took place.

The ethnographic information gathered by my research seems to point toward the need for other concepts or paradigms in addition to the activity area, because the proponents of this concept do not take into account the ease with which certain activities are performed indistinctly in one place or another within the house, or are started in one place and finished in another, as we have seen in Huáncito. The activity-area concept is certainly a valid proposition and is very relevant to archaeology in Mesoamerica and elsewhere. Archaeologists, however, should have a more holistic, complete, and integral understanding of all activities usually performed in a household, both those that are linked to the ceramic process and those that are not. This would allow us to fully understand the structure of the spatial context and the organization of domestic work. These perspectives can be obtained or enhanced through ethnographic observation in contemporary communities, and the insights gained by ethnographic analogy should be applied to the interpretation of the archaeological record.

Mitchell et al. (2006) have explored the way in which people organize their living space and how ethnographic studies of such behavior can be applied to archaeological situations. A case in point is the understanding of the way in which South African hunter-gatherers structured their campsites and organized the space within them. This has been a long-standing theme of ethnographic fieldwork among surviving Bushman peoples in the Kalahari Desert of South Africa, often with a specific interest in the insights that this may generate for archaeological studies about hunter-gatherers, in particular, and, more generally, for archaeological research in other areas of the world (Mitchell et al. 2006:81).

Another important input to ethnoarchaeological studies of the use of cultural space comes from Jarvenpa and Brumbach (2006), who set out to "reassess one of the bedrock concepts of anthropology and social sciences: the sexual division of labor". In their opinion, archaeologists who assume a rigid division of labor in all 


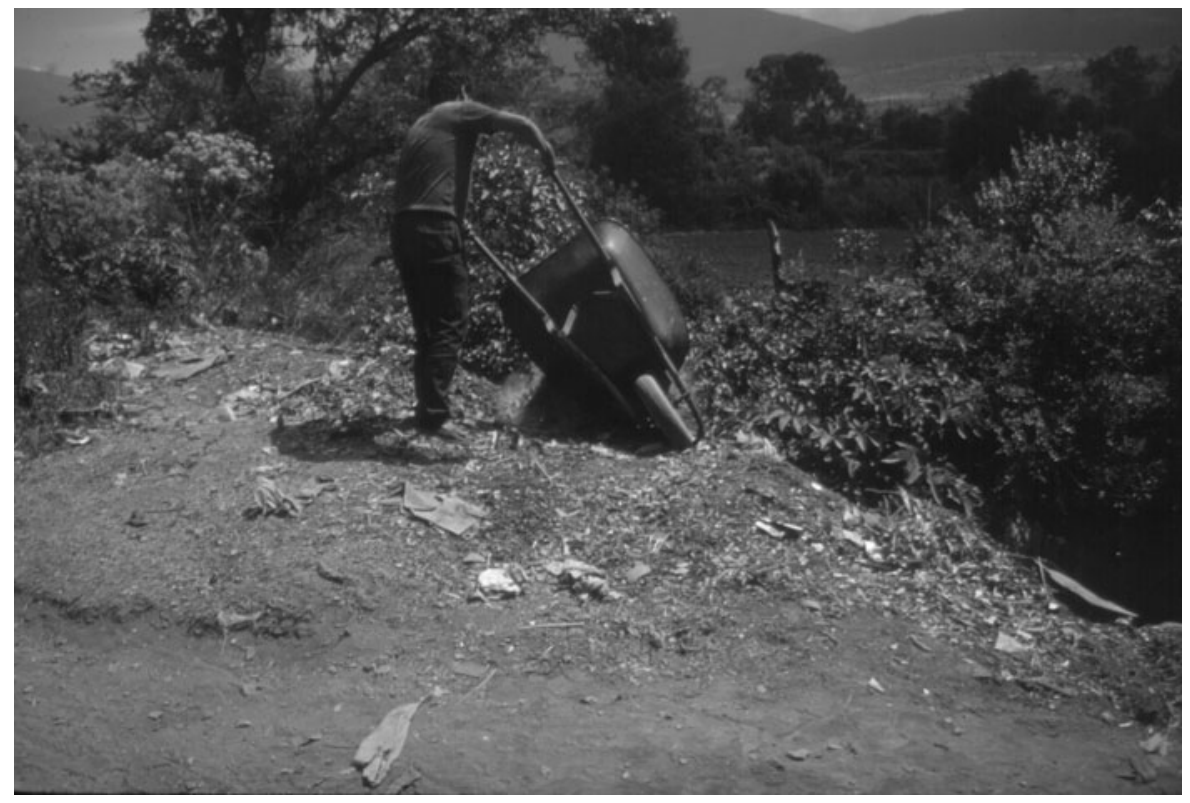

Figure 32. The potsherds are periodically discarded in a gully on the outskirts of Huáncito (1990). Photograph by author.

societies throughout the modern world may be projecting their Western beliefs onto the archaeological record (Jarvenpa and Brumbach 2006:97). In discussing specialization within the household, these authors argue that "specialization allows families and other small-scale social units to perform a wider array of tasks and skills than any individual alone could master" (Jarvenpa and Brumbach 2006:98).

The work of Rapoport (1990) has been particularly important to understand the archaeological implications of the behavior we see among potters in the Huáncito households. According to
Rapoport, "the notion of 'activities' is not at all self-evident and needs clarification both regarding the relation of activities to culture and also in terms of four aspects of activities" ranging from (1) instrumental aspects which are the most obvious (the nature of the activities); (2) how activities are carried out; (3) how they are associated into systems; and, lastly, (4) the meaning or most latent aspect of all activities.

Rapoport (1990:9) holds that "one cannot discuss single activities but only systems of activities... [their] setting also cannot be considered singly but only as systems, so that systems of activities

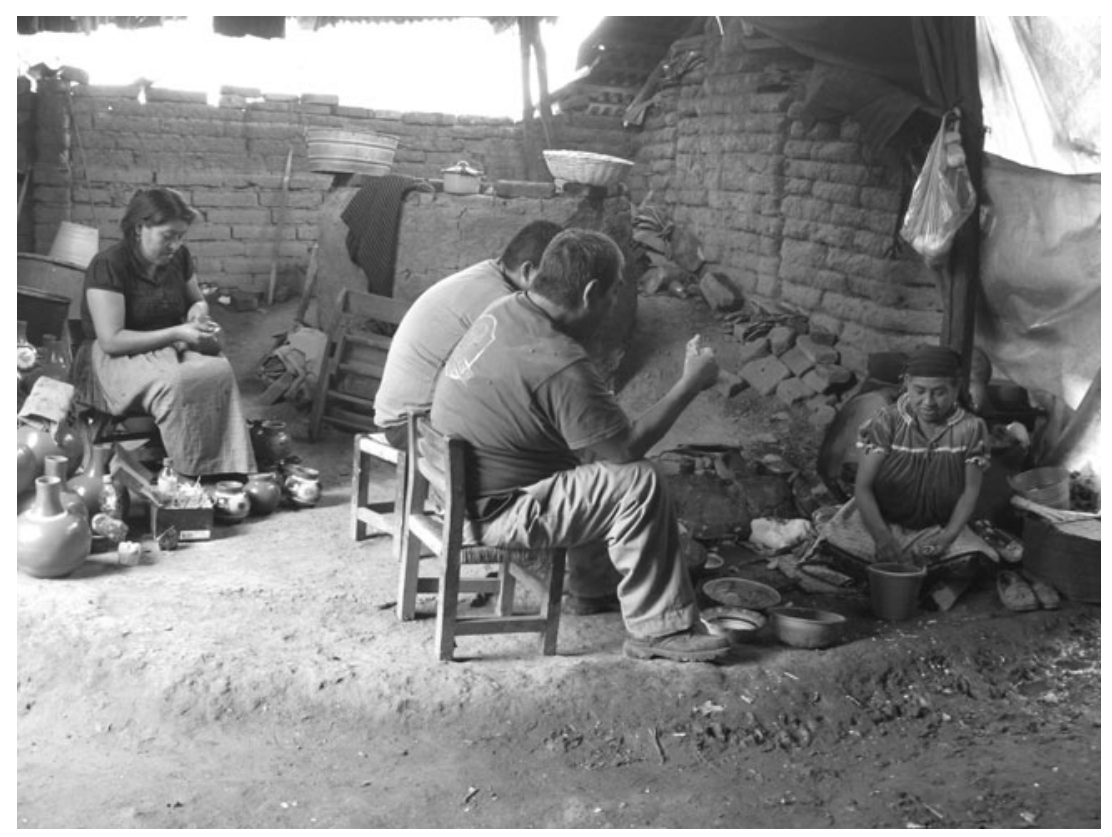

Figure 33. A small adobe stove has been built for cooking in the area near the kiln in Fidel's house. Lafira is seen cooking at far right, while Fidel and Magdaleno are eating in the middle, and Marina is working at the left of the figure (painting pots). This is an example of the flexibility of domestic space mentioned in the text (Fidel Lorenzo household, 2014). Photograph by author. 


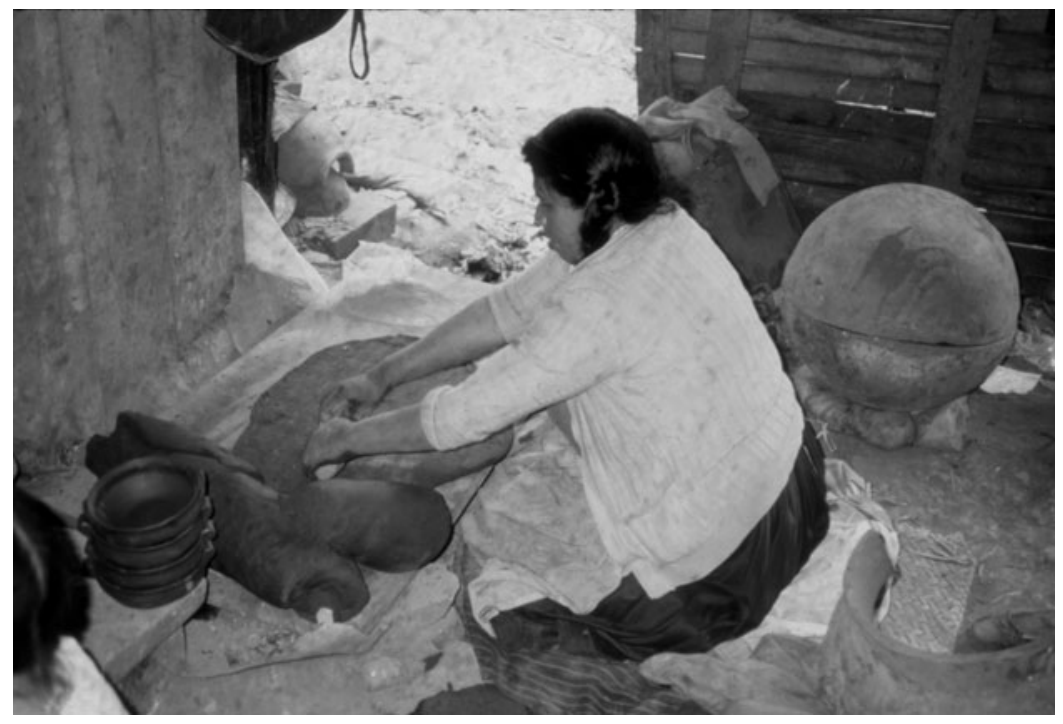

Figure 34. Some tools used by potters in their daily work would be difficult to identify in the archaeological record, for instance the handstones or manos used to make a flat clay "tortilla," as opposed to those used to grind corn. A microscopic analysis would help to identify the actual use given to these objects in the household (1990). Photograph by author.

actually occur in systems of settings. These are organized in varying and complex ways, not only in space but in time and in other ways, all related to culture." The implication of these observations is that "what happens in one part of the system greatly influences what happens or does not happen elsewhere[.]" Rapoport (1990:9) adds that "a particular way of addressing an important question regarding environment-behavior interaction" is "who does what, where, when, including or excluding whom (and why)."

Table 5. Activities and associated archaeological markers of pottery-producing households. Most of the archaeological markers of household pottery production will not always be found in situ, because they are usually moved from the original context by sweeping, cleaning, and other maintenance activities.

\begin{tabular}{|c|c|}
\hline Activity & Archaeological markers \\
\hline Firing in kiln & $\begin{array}{l}\text { Firing structure, wasters, potsherds, fire stains on } \\
\text { floor, ash concentrations, chemical changes in soil, } \\
\text { carbon remains, clay concretions, pebbles, and bits } \\
\text { of daub. }\end{array}$ \\
\hline Firing in the open & $\begin{array}{l}\text { Wasters, potsherds, fire stains on floor, ash } \\
\text { concentrations, chemical changes in soil, and carbon } \\
\text { remains. }\end{array}$ \\
\hline Production for trade & $\begin{array}{l}\text { Stored vessels in larger amounts than normal } \\
\text { household requirements. }\end{array}$ \\
\hline Clay processing & $\begin{array}{l}\text { Big rocks for grinding clay, materials used as temper } \\
\text { (e.g., small stone fragments), and grindstones } \\
\text { (metates, manos, and molcajetes). }\end{array}$ \\
\hline Shaping pots & Molds. \\
\hline $\begin{array}{l}\text { Polishing/ } \\
\text { burnishing pots }\end{array}$ & $\begin{array}{l}\text { Small stones or other suitable artifacts (with use } \\
\text { marks). }\end{array}$ \\
\hline Painting pots & $\begin{array}{l}\text { Charanda and other mineral colorants, stored in } \\
\text { house or splattered on soil in work areas. }\end{array}$ \\
\hline Discard & $\begin{array}{l}\text { Concentrations of broken, misfired, or otherwise } \\
\text { defective pots and potsherds. }\end{array}$ \\
\hline
\end{tabular}

My work dealing with pottery manufacture and use in the context of domestic space has explored the systemic context and its archaeological implications in only three cases for a limited period of time. Much remains to be done, but the results so far have been extremely illuminating and encouraging.

\section{CONCLUSIONS}

Sabloff (1990) says that, until the first half of the twentieth century, most archaeologists working in Mesoamerica were preoccupied mainly with deciphering the function of artifacts, and with placing them in time and space. Today, the goals of archaeology are much more ambitious: to understand and explain the processes of cultural change over long periods of time. The traditional or normative viewpoint, derived from the perspective that dominated American cultural anthropology during most of the last century, emphasized the shared ideas expressed in cultural features. Cultures were characterized by long lists of traits, like the way of making and decorating pottery. The general emphasis was on cultural homogeneity (Sabloff 1990:5-8). The study presented in this article has much more ambitious goals: to generate a corpus of middle-range research (following Binford 1983) to understand the archaeological record of pottery production, use, and discard by means of ethnographic analogy (Williams 2005).

This study is focused on the way that potters organize their work at the household level, including the procurement of clay, the ways in which clay is transformed into pots of many types and shapes in the domestic workshops, and the ecological impact of firing the potter's kiln with wood from the nearby hills as the only source of energy (also used for cooking). Another archaeologically oriented aspect of my ethnographic work in Huáncito has to do with the use of space in the households and the "archaeological visibility" of pottery manufacture, in the context of what archaeologists have conceptualized as "activity areas" in Mesoamerica and elsewhere. In this regard, De Lucia's (2013) research in pre-Hispanic houses in Xaltocan is relevant to my discussion of archaeological 
markers and the use of domestic space because she used a fresh approach to household archaeology, taking into account many ethnoarchaeological examples in order to shed light on her research.

Around A.D. 900-1350, household production strategies in Xaltocan included a diversity of activities, or multicrafting (De Lucia 2013:353). An area of the site was heavily covered in ash, suggesting that food preparation or pottery manufacture may have taken place there, while another area may have been dedicated to reed mat production, as suggested by stones used for flattening the plant stalks (De Lucia 2013:358-359) like those reported by Williams (2009, 2014b, 2014c).

One important fact highlighted by De Lucia (2013:354) is that "houses in Mesoamerica were meticulously swept, often on a daily basis, therefore few macroartifacts tend to remain in situ on house floors for interpreting activity areas. Moreover, when houses were abandoned they were typically cleared of tools and useful materials[.]" This makes it difficult "for archaeologists to identify production areas or understand how activities were organized at the household level. Even when artifacts are recovered directly from room floors, they do not necessarily represent their original contexts of use, as these objects are portable and may have been moved." This caveat is based on ethnographic observation, such as the study of Hayden and Cannon (1983) in Maya households.

To conclude, I would like to stress the role of households "as essential building blocks in the reconstruction of past societies" (Allison 1999:1). According to Allison, "an understanding of the nature of change in household organization would bridge the existing 'mid-level theory gap' in archaeology[.]" In fact, in order "to understand the power of domestic space as a social construct, one must look beyond ritual action and grand cosmological belief systems and into the practical actions of daily life[.]" The role of middle-range (i.e., ethnographic) research is critical, because "archaeologists do not dig up households. They dig up dwellings and domestic artefacts but not social units. A household is an ethnographic phenomenon, not an archaeological one" (Allison 1999:2). This is why "ethnography [is] fundamental... to the study of households in archaeology. However[, we] should not... simply... use ethnographic data to describe household behaviour in the past but to use it also to highlight the potential for diversity and change in domestic worlds..." (Allison 1999:3).

We cannot end this article without referring to the social and cultural changes that have affected the Tarascan people and other ethnic groups in Mexico and elsewhere. Patricia Fournier $(2008: 5,7)$ points out that although Michoacán still has many pottery-producing communities, many more have disappeared or have seen their traditions transformed: "the ancestral techniques and shapes have been lost or are slowly disappearing." Fournier (2008) thinks that crafts are an important component of Mexico's cultural heritage, one whose transmission depends on social identity and memory. In her view, crafts producers are part of a living culture, in many instances the last carriers of traditions currently in a process of disintegration.

Today, the Tarascans, Mexico itself, and the rest of the world are immersed in a process of "globalization." Certainly subordinate groups in Mexico, including most indigenous communities, now find themselves inserted into a social and economic system that does not favor them. In the case of Huáncito and other indigenous communities and cultures, pottery making and other crafts have become a survival strategy in the face of adversity, but this does not mean that crafts cease to be elements of cultural identity, worldview, or cosmovision, as well as a source of pride and an expression of the creativity that has always characterized all Mesoamerican indigenous peoples.

\section{RESUMEN}

El pueblo de Huáncito está ubicado en la Cañada de los Once Pueblos (Michoacán). Esta es una comunidad tarasca (o purépecha), donde el autor ha estado trabajando desde mediados de 1990 hasta la fecha. Si bien el cambio cultural observado por el autor en los últimos 26 años ha sido considerable, la producción de cerámica sigue vigente y se puede decir que la tradición alfarera persiste con técnicas tradicionales, aunque los estilos decorativos han cambiado bastante.

La investigación etnográfica se ha apoyado en la observación participante dentro de las unidades domésticas de Huáncito. Además realizamos entrevistas (de formato libre) y aplicamos cuestionarios en diferentes partes del poblado, en los que se tocan temas como: tipo de combustible empleado para los hornos de alfarero y para cocinar; consumo diario de leña en las casas; actividad principal de la unidad doméstica; actividades secundarias (p. ej. agricultura, comercio); número de hornos y frecuencia de uso; cantidad de cargas de leña empleadas en cada quema; tipo de vasijas producidas; decoración de las vasijas (colorantes naturales o artificiales, descripción de los diseños, etc.); finalmente la comercialización (p. ej. si venden sus productos directamente en el pueblo o a través de intermediarios).

Uno de los temas tratados en la investigación es el de la organización espacial de la producción doméstica de objetos de barro, sobre todo porque tenemos una perspectiva diacrónica en la que hemos observado cambios estructurales en las casas y en las familias a lo largo de más de dos décadas y media. El enfoque etnográfico nos permite entender qué actividades productivas ocurren en los espacios domésticos y cuáles son sus consecuencias materiales (arqueológicas). Esto lo hemos logrado siguiendo una perspectiva comparativa con otras áreas de Mesoamérica y de otras partes del mundo.

Para entender el uso del espacio en los hogares (que son a la vez talleres) hicimos planos detallados de tres casas, observando y registrando las actividades cotidianas por espacio de unos seis meses. El resultado final fue un palimpsesto, en donde vemos la sobreposición de actividades. La conclusión a la que llegamos es que el uso del espacio es indiferenciado, es decir las actividades pueden llevarse a cabo en prácticamente cualquier sitio dentro de la casa, o bien varias actividades pueden realizarse en un solo lugar en distintos momentos.

La observación a nivel etnográfico de las actividades dentro de las unidades domésticas nos permitió llegar a la conclusión de que muchas de las acciones de los artesanos no tienen una "visibilidad arqueológica" tangible, y de que el uso del espacio es poco sistemático. También notamos que las actividades de limpieza (por ejemplo barrer el piso de la casa) usualmente destruyen o desplazan los restos materiales que podrían ser "indicadores arqueológicos." En síntesis, nos interesa principalmente buscar rasgos diagnósticos de las actividades productivas de la alfarería tradicional. 


\section{ACKNOWLEDGMENTS}

First and foremost, I should like to thank the potters of Huáncito, who have always been gracious hosts and have patiently answered all my questions about their craft and many other aspects of their life.

This article is a summary adaptation of Chapter III of my book Tarascan Pottery Production in Michoacán, Mexico: An Ethnoarchaeological Perspective (Archaeopress, Oxford, 2017). Jeffrey Parsons, Helen Pollard, and Michael Shott read the first draft of the book and offered very useful

\section{REFERENCES}

Acuña, René (editor)

1987 Relaciones geográficas del siglo XVI: Michoacán. Universidad Nacional Autónoma de México, Mexico City.

Adams, William H.

1987 Review of Analyzing Activity Areas: An Ethnoarchaeological Study of the Use of Space, by Susan Kent. Historical Archaeology 21:105-107.

Allison, Penelope M.

1999 Introduction. In The Archaeology of Household Activities, edited by Penelope M. Allison, pp. 1-18. Routledge, Oxford.

Arnold, Dean E.

1985 Ceramic Theory and Cultural Process. Cambridge University Press, Cambridge.

1989 Patterns of Learning, Residence, and Descent among Potters in Ticul, Yucatan, Mexico. In Archaeological Approaches to Cultural Identity, edited by Stephen Shennan, pp. 174-184. Unwin Hyman, London.

1991 Ethnoarchaeology and Investigations of Ceramic Production and Exchange: Can We Go Beyond Cautionary Tales? In The Ceramic Legacy of Anna O. Shepard, edited by Ronald L. Bishop and Frederick W. Lange, pp. 321-345. University Press of Colorado, Niwot.

1999 Advantages and Disadvantages of Vertical-Half Molding Technology: Implications for Production Organization. In Pottery and People: A Dynamic Interaction, edited by James M. Skibo and Gary M. Feinman, pp. 59-80. The University of Utah Press, Salt Lake City.

2008 Social Change and the Evolution of Ceramic Production and Distribution in a Maya Community. University Press of Colorado, Boulder.

Arnold III, Philip J.

1991 Domestic Ceramic Production and Spatial Organization: A Mexican Case Study in Ethnoarchaeology. Cambridge University Press, Cambridge.

2005 El quemado de las ollas en la Sierra de los Tuxtlas, Veracruz: un estudio de ecología cerámica. In Etnoarqueología: el contexto dinámico de la cultura material a través del tiempo, edited by Eduardo Williams, pp. 35-54. El Colegio de Michoacán, Zamora.

Bankes, George

1980 Moche Pottery from Peru. British Museum Publications, London.

Barba, Luis

2016 Estudios de residuos químicos en pisos de unidades domésticas en Tlaxcala: Pasado y presente. Arqueología Mexicana 24:71-75.

Bate, Luis Felipe

1988 El proceso de investigación en arqueología. Grijalbo Mondadori, Barcelona.

Beals, Ralph L.

1969 The Tarsacans. In Ethnology, edited by Robert Wauchope, pp. 725-776. Handbook of Middle American Indians, Vol. 8, Part II. University of Texas Press, Austin.

Berdan, Frances

2014 Aztec Archaeology and Ethnohistory. Cambridge University Press, Cambridge.

Binford, Lewis R.

1983 In Pursuit of the Past: Decoding the Archaeological Record. Thames and Hudson, New York.

1986 An Alyawara Day: Making Men's Knives and Beyond. American Antiquity 51:547-562.

Canto Aguilar, Giselle

1986 Proposiciones para el estudio de talleres de producción cerámica. In Unidades habitacionales mesoamericanas y sus áreas de actividad, suggestions. I am solely responsible, however, for the ideas and conclusions expressed herein.

I have received financial support for fieldwork from the British Academy (1990) and the Wenner-Gren Foundation for Anthropological Research, Inc. (Research Grant 1991; International Collaborative Grant, with Dr. Michael Shott, 1998 and 2000). The Colegio de Michoacán gave some financial backing for fieldwork and for drafting the final version of the book. edited by Linda Manzanilla, pp. 41-58. Universidad Nacional Autónoma de México, Mexico City.

David, Nicholas, and Carol Kramer

2001 Ethnoarchaeology in Action. Cambridge University Press, Cambridge.

Deal, Michael

1988 An Ethnoarchaeological Approach to the Identification of Maya Domestic Pottery Production. In Ceramic Ecology Revisited 1987: The Technology and Socioeconomics of Pottery, edited by Charles C. Kolb, pp. 111-142. BAR International Series 436. British Archaeological Reports, Oxford.

De Lucia, Kristin

2013 Domestic Economies and Regional Transition: Household Multicrafting and Lake Exploitation in Pre-Aztec Central Mexico. Journal of Anthropological Archaeology 32:353-367.

De Lucia, Kristin, and Lisa Overholtzer

2014 Everyday Action and the Rise and Decline of Ancient Polities: Household Strategy and Political Change in Postclassic Xaltocan, Mexico. Ancient Mesoamerica 25:441-458.

Douglass, John G., and Nancy Gonlin (editors)

2012 Ancient Households of the Americas: Conceptualizing What Households Do. University Press of Colorado, Boulder.

Feinman, Gary

2001 Crafts and Craft Specialization. In Archaeology of Ancient Mexico and Central America: An Encyclopedia, edited by Susan T. Evans and Daniel L. Webster, pp. 191-195. Garland Publishing, New York.

Feinman, Gary, and Linda Nicholas

2011 Domestic Craft Production and the Classic Period Economy of Oaxaca. In Producción artesanal y especializada en Mesoamérica: áreas de actividad y procesos productivos, edited by Linda Manzanilla and Kenneth G. Hirth, pp. 29-58. Instituto Nacional de Antropología e Historia and Universidad Nacional Autónoma de México, Mexico City.

2012 The Late Prehispanic Economy of the Valley of Oaxaca, Mexico. Research in Economic Anthropology 32:225-258.

Fewkes, Jesse

1901 Tusayan Migration Traditions. Washington Government Printing Office, Washington, DC.

Flannery, Kent V.

1976 Research Strategy and Formative Mesoamerica. In The Early Mesoamerican Village, edited by Kent V. Flannery, pp. 1-12. Academic Press, New York.

1986 Spatial Analysis of Guilá Naquitz Living Floors: An Introduction to Part VI. In Guilá Naquitz: Archaic Foraging and Early Agriculture in Oaxaca, Mexico, edited by Kent V. Flannery, pp. 319-330. Academic Press, Orlando.

Flannery, Kent V., and Marcus C. Winter

1976 Analyzing Household Activities. In The Early Mesoamerican Village, edited by Kent V. Flannery, pp. 31-47. Academic Press, New York.

Foster, George

1948 Some Implications of Modern Mexican Mold-Made Pottery. Southwestern Journal of Anthropology 4:356-370.

1955 Contemporary Pottery Techniques in Southern and Central Mexico. Middle-American Research Institute Publication 22. Tulane University, New Orleans.

1960 Archaeological Implications of the Modern Pottery of Acatlán, Puebla, Mexico. American Antiquity 26:205-214.

1965 The Sociology of Pottery: Questions and Hypotheses Arising from Contemporary Mexican Work. In Ceramics and Man, edited by Frederick R. Matson, pp. 43-61. Viking Fund Publications in 
Anthropology, No. 41. Wenner-Gren Foundation for Anthropological Research, New York.

1967 Contemporary Pottery and Basketry. In Social Anthropology, edited by Manning Nash, pp. 103-124. Handbook of Middle-American Indians, Vol. 6. University of Texas Press, Austin.

Fournier, Patricia

2008 La producción alfarera contemporánea en México: Etnoarqueología de rescate del patrimonio cultural intangible. In Perspectivas de la investigación arqueológica, Vol. III, edited by Fernando López Aguilar, Walburga Wiesheu, and Patricia Fournier, pp. 1-33. Consejo Nacional para la Cultura y las Artes and Instituto Nacional de Antropología e Historia, Mexico City.

Franco, Moisés

1997 La ley y la costumbre en La Cañada de los Once Pueblos. El Colegio de Michoacán, Zamora.

Friedrich, Paul

1970 Agrarian Revolt in a Mexican Village. Prentice-Hall, Englewood Cliffs.

Gougeon, Ramie A.

2012 Activity Areas and Households in the Late Mississippian Southeast United States: Who Did What Where? In Ancient Households of the Americas: Conceptualizing What Households Do, edited by John G. Douglass and Nancy Gonlin, pp. 141-162. University Press of Colorado, Boulder.

Hardin, Margaret

1970 Design Structure and Social Interaction: Archaeological Implications of an Ethnographic Analysis. American Antiquity 35:332-342.

Hayden, Brian, and A. Cannon

1983 Where the Garbage Goes: Refuse Disposal in the Maya Highlands. Journal of Anthropological Archaeology 2:117-163.

Healan, Dan

2014 Comments to the Symposium City, Crafts, and Residence in Mesoamerica: Papers Presented in Honor of Dan Healan. Paper presented at the 79th Annual Meeting of the Society for American Archaeology, Austin.

Hirshman, Amy

2011 Un modelo para la organización de la producción cerámica en la cuenca de Pátzcuaro en la época prehispánica. In Patrones de asentamiento y actividades de subsistencia en el occidente de México: reconocimiento a la Dra. Helen P. Pollard, edited by Eduardo Williams and Phil C. Weigand, pp. 209-230. El Colegio de Michoacán, Zamora

Hirth, Kenneth

2009 Craft Production, Household Diversification, and Domestic Economy in Prehispanic Mesoamerica. In Housework: Craft Production and Domestic Economy in Ancient Mesoamerica, edited by Kenneth G. Hirth, pp. 13-32. Archaeological Papers of the American Anthropological Association, No. 19. American Anthropological Association, Washington, DC.

2011 Introducción: La naturaleza e importancia de la producción artesanal. In Producción artesanal y especializada en Mesoamérica: Áreas de actividad y procesos productivos, edited by Linda Manzanilla and Kenneth G. Hirth, pp. 13-28. Instituto Nacional de Antropología e Historia and Universidad Nacional Autónoma de México, Mexico City.

2013 Economic Consumption and Domestic Economy in Cholula's Rural Hinterland, Mexico. Latin American Antiquity 24:123-148.

Jarvenpa, Robert, and Hetty Jo Brumbach

2006 Revisiting the Sexual Division of Labor: Thoughts on Ethnoarchaeology and Gender. In Integrating the Diversity of Twenty-First Century Anthropology: The Life and Intellectual Legacies of Susan Kent, edited by Wendy Ashmore, Marcia Dobres, Sarah Milledge Nelson, and Arlene Rosen, pp. 97-107. Archaeological Papers of the American Anthropological Association, No. 16(1). University of California Press, Berkeley.

Jiménez Castillo, Manuel

1982 Huáncito: La alfarería en una comunidad purépecha. Universidad Autónoma Metropolitana, Azcapotzalco.

Joaquín, Jorge Antonio

1982 La tierra y los artesanos de Huáncito, Michoacán. Etnolingüística 40. Secretaría de Educación Publica and Instituto Nacional de Antropología e Historia, Mexico City.

Kemper, John

2010 Tzintzuntzan, Michoacán: Cuatro décadas de investigaciones antropológicas. El Colegio de Michoacán, Zamora.
Kent, Susan

1984 Analyzing Activity Areas: An Ethnoarchaeological Study of the Use of Space. University of New Mexico Press, Albuquerque.

1990 Activity Areas and Architecture: An Interdisciplinary View of the Relationship between Use of Space and Domestic Built Environments. In Domestic Architecture and the Use of Space: An Interdisciplinary Cross-Cultural Study, edited by Susan Kent, pp. 1-8. Cambridge University Press, Cambridge.

Kolb, Charles C.

1989 Ceramic Ecology in Retrospect: A Critical Review of Methodology and Results. In Ceramic Ecology, 1988: Current Research on Ceramic Materials, edited by Charles C. Kolb, pp. 261-375. BAR International Series 513. British Archaeological Reports, Oxford.

Krotser, Paula

1980 Potters in the Land of the Olmec. In In the Land of the Olmec, Vol. 2: People of the River, by Michael D. Coe and Richard A. Diehl, pp. 125-138. University of Texas Press, Austin.

Lackey, Louana

1982 The Pottery of Acatlán: A Changing Mexican Tradition. University of Oklahoma Press, Norman.

Longacre, William A.

1991 Ceramic Ethnoarchaeology: An Introduction. In Ceramic Ethnoarchaeology, edited by William A. Longacre, pp. 1-10. University of Arizona Press, Tucson.

Manzanilla, Linda

1986 Introducción. In Unidades habitacionales mesoamericanas y sus áreas de actividad, edited by Linda Manzanilla, pp. 9-18. Universidad Nacional Autónoma de México, Mexico City.

2009 Corporate Life in Apartment and Barrio Compounds at Teotihuacan, Central Mexico. In Domestic Life in Prehispanic Capitals: A Study of Specialization, Hierarchy, and Ethnicity, edited by Linda Manzanilla and Claude Chapdelaine, pp. 21-42. Memoirs of the Museum of Anthropology, Vol. 46. University of Michigan, Ann Arbor.

Metcalfe, Duncan, and Kathleen M. Heath

1990 Microrefuse and Site Structure: The Hearths and Floors of the Heartbreak Hotel. American Antiquity 55:781-796.

Migeon, Gérald

1985 Tradición oral, arqueología e historia: El caso de Ichán, Michoacán. Trace 8:52-56.

Mitchell, Peter, Ina Plug, and Geoff Bailey

2006 Spatial Patterning and Site Occupation at Likoaeng, an Open-Air Hunter-Gatherer Campsite in the Lesotho Highlands, Southern Africa. In Integrating the Diversity of Twenty-First Century Anthropology: The Life and Intellectual Legacies of Susan Kent, edited by Wendy Ashmore, Marcia Dobres, Sarah Milledge Nelson, and Arlene Rosen, pp. 81-94. Archaeological Papers of the American Anthropological Association, No. 16. University of California Press, Berkeley.

O'Connell, James F.

1987 Alyawara Site Structure and its Archaeological Implications. American Antiquity 52:74-108.

Pollard, Helen P.

2009 Un modelo para el surgimiento del Estado tarasco. In Las sociedades complejas del Occidente de México en el mundo mesoamericano: Homenaje al Dr. Phil C. Weigand, edited by Eduardo Williams, Lorenza López Mestas, and Rodrigo Esparza, pp. 225-253. El Colegio de Michoacán, Zamora.

2011a Una larga caminata: El análisis regional dentro de la arqueología tarasca. In Patrones de asentamiento y actividades de subsistencia en el Occidente de México: Reconocimiento a la Dra. Helen Perlstein Pollard, edited by Eduardo Williams and Phil C. Weigand, pp. 21-34. El Colegio de Michoacán, Zamora.

2011b La economía política de la metalurgia en el Estado tarasco. In Patrones de asentamiento y actividades de subsistencia en el Occidente de México: Reconocimiento a la Dra. Helen Perlstein Pollard, edited by Eduardo Williams and Phil C. Weigand, pp. 281-296. El Colegio de Michoacán, Zamora.

Ramírez, Luis Alfonso

1986 Chilchota: un pueblo al pie de la sierra. El Colegio de Michoacán, Zamora.

Rapoport, Amos

1990 Systems of Activities and Systems of Settings. In Domestic 
Architecture and the Use of Space: An Interdisciplinary Cross-Cultural Study, edited by Susan Kent, pp. 9-19. Cambridge University Press, Cambridge.

Rattray, Evelyn C.

1990 New Findings on the Origins of Thin Orange Ceramics. Ancient Mesoamerica 1:181-196.

Rice, Prudence M.

2015 Pottery Analysis: A Sourcebook. 2nd ed. University of Chicago Press, Chicago.

Sabloff, Jeremy A.

1990 The New Archaeology and the Ancient Maya. Scientific American Library, New York.

Sahagún, Bernardino

1961 Florentine Codex: General History of the Things of New Spain. Book 10: The People, edited by Charles Dibble and Arthur J. Anderson. School of American Research and University of Utah Press, Santa Fe and Salt Lake City.

Schiffer, Michael B.

1988 The Structure of Archaeological Theory. American Antiquity 53: 461-485.

Sheehy, James J.

1988 Ceramic Ecology and the Clay/Fuel Ratio: Modeling Fuel Consumption in Tlajinga 33, Teotihuacan, Mexico. In Ceramic Ecology Revisited 1987: The Technology and Socioeconomics of Pottery, edited by Charles C. Kolb, pp. 199-226. BAR International Series 436. British Archaeological Reports, Oxford.

1992 Ceramic Production in Ancient Teotihuacan, Mexico: A Case Study of Tlajinga 33. Ph.D. dissertation, Department of Anthropology, Pennsylvania State University, University Park.

Shimada, Izumi, and Ursel Wagner

2007 A Holistic Approach to Pre-Hispanic Craft Production. In Archaeological Anthropology: Perspectives on Method and Theory, edited by James S. Skibo, Michael W. Graves, and Miriam T. Stark, pp. 163-197. University of Arizona Press, Tucson.

Shott, Michae

1998 Status and Role of Formation Theory in Contemporary Archaeological Practice. Journal of Archaeological Research 6:299-329.

Shott, Michael, and Eduardo Williams

2001 Datos censales sobre la vida útil de la cerámica: Estudio etnoarqueológico en Michoacán. In Estudios cerámicos en el occidente y norte de México, edited by Eduardo Williams and Phil C. Weigand, pp. 97-126. El Colegio de Michoacán and Instituto Michoacano de Cultura, Zamora and Morelia.

2006 Purépecha Pottery Ethnoarchaeology. In Integrating the Diversity of Twenty-First-Century Anthropology: The Life and Intellectual Legacies of Susan Kent, edited by Wendy Ashmore, Marcia Dobres, Sarah Milledge Nelson, and Arlene Rosen, pp. 47-56. Archaeological Papers of the American Anthropological Association, No. 16. University of California Press, Berkeley.

Simms, Steven R. and K. M. Heath

1990 Site Structure in the Orbit Inn: An Application of Ethnoarchaeology. American Antiquity 55:797-812.

Smith, Michael E.

2004 Los hogares de Morelos en el sistema mundial mesoamericano posclásico. Relaciones: Estudios de Historia y Sociedad 25:79-113.

2016 Aztec Urbanism: Cities and Towns. In Oxford Handbook of the Aztecs, edited by Deborah L. Nichols and Enrique Rodriguez-Alegría, pp. 201-217. Oxford University Press, Oxford.

\section{Stark, Barbara}

1984 An Ethnoarchaeological Study of a Mexican Pottery Industry. Journal of New World Archaeology 6:4-14.

Sugiura, Yoko

2011 Innovaciones y proceso técnico de producción alfarera en el Valle de Toluca: Etnoarqueología e implicaciones para la arqueología. In
Mesoamérica: Debates y perspectivas, edited by Eduardo Williams, Magdalena García, Phil C. Weigand, and Manuel Gándara, pp. 115-130. El Colegio de Michoacán, Zamora.

Sugiura, Yoko, and Mari Carmen Serra

1990 Significado del espacio: el caso de la producción alfarera del valle de Toluca. In Etnoarqueología: Primer coloquio Bosch-Gimpera, edited by Yoko Sugiura and Mari Carmen Serra, pp. 201-218. Universidad Nacional Autónoma de México, Mexico City.

Thompson, Raymond H.

1991 The Archaeological Purpose of Ethnoarchaeology. In Ceramic Ethnoarchaeology, edited by William Longacre, pp. 231-246. University of Arizona Press, Tucson.

Van Leeuwen, Theo

2008 Discourse and Practice: New Tools for Critical Analysis. Oxford University Press, Oxford.

West, Robert C.

1948 Cultural Geography of the Modern Tarascan Area. Institute of Social Anthropology, Publication No. 7. Smithsonian Institution, Washington, DC.

Williams, Eduardo

1994a Ecología cerámica en Huáncito, Michoacán. In Arqueología del occidente de México: Nuevas aportaciones, edited by Eduardo Williams and Robert Novella, pp. 319-363. El Colegio de Michoacán, Zamora.

1994b Organización del espacio doméstico y producción cerámica en Huáncito, Michoacán. In Contribuciones a la arqueología y etnohistoria del Occidente de México, edited by Eduardo Williams, pp. 189-226. El Colegio de Michoacán, Zamora.

1995 Supervivencias prehispánicas en la cerámica tradicional del Occidente de México. In Tradición e identidad en la cultura mexicana, edited by Agustín Jacinto and Alvaro Ochoa, pp. 205-234. El Colegio de Michoacán, Zamora.

2005 Introducción. In Etnoarqueología: El contexto dinámico de la cultura material a través del tiempo, edited by Eduardo Williams, pp. 13-34. El Colegio de Michoacán, Zamora.

2009 The Exploitation of Aquatic Resources at Lake Cuitzeo, Michoacán, Mexico: An Ethnoarchaeological Study. Latin American Antiquity 20:607-627.

2014a Cambio social y continuidad cultural en la cerámica de Huáncito, Michoacán, México. Materialidades: Perspectivas Actuales en Cultura Material 2:122-152.

2014b Water Folk: Reconstructing an Ancient Aquatic Lifeway in Michoacán, Western Mexico. BAR International Series 2617. British Archaeological Reports, Oxford.

2014c La gente del agua: etnoarqueología del modo de vida lacustre en Michoacán. El Colegio de Michoacán, Zamora.

2014d Reconstructing an Ancient Aquatic Lifeway in the Lake Cuitzeo Basin, Michoacán, Mexico. Ancient Mesoamerica 25:49-67.

2015 The Salt of the Earth: Ethnoarchaeology of Salt Production in Michoacán, Western Mexico. BAR International Series 2725. British Archaeological Reports, Oxford.

2016a Domestic Production and Decoration Styles in Pottery from Huáncito, Michoacán: An Ethnoarchaeological Study. In Cultural Dynamics and Production Activities in Ancient Western Mexico, edited by Eduardo Williams and Blanca Maldonado, pp. 131-166. Archaeopress, Oxford.

2016b Materialidad, naturaleza y cosmovisión en la cerámica purépecha de Huáncito, Michoacán, México. Materialidades: Perspectivas Actuales en Cultura Material 4:110-143.

2017 Tarascan Pottery Production in Michoacán, Mexico: An Ethnoarchaeological Perspective. Archaeopress, Oxford.

Wylie, Alison

2002 Thinking from Things: Essays in the Philosophy of Archaeology. University of California Press, Berkeley. 